

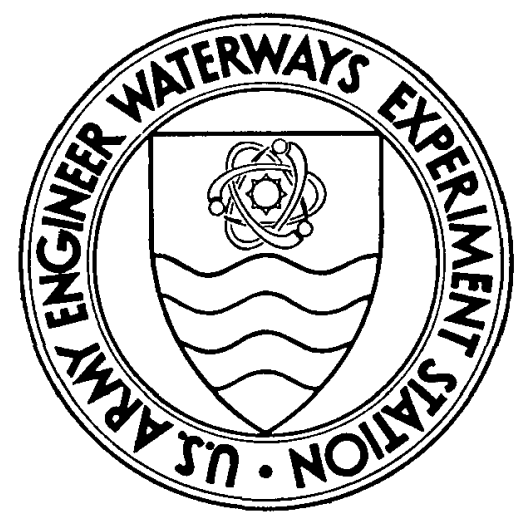

MISCELLANEOUS PAPER C-7I-2

\section{THE INFLUENCE OF VARIATION IN GRAIN SIZE AND MINIMAL VARIATION IN ROCK TYPE ON THE QUALITY OF ROCK PROPERTY CORRELATIONS FOR INTACT IGNEOUS ROCKS \\ by}

R. W. Crisp

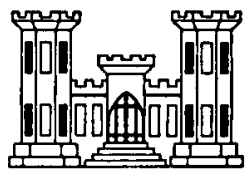

February 1971

Published by U. S. Army Engineer Waterways Experiment Station, Vicksburg, Mississippi 
W34m

No.c $-71-2$

Cop.z

THE CONTENTS OF THIS REPORT ARE NOT TO BE USED FOR ADVERTISING, PUBLICATION, OR PROMOTIONAL PURPOSES. CITATION OF TRADE NAMES DOES NOT CONSTITUTE AN OFFICIAL ENDORSEMENT OR APPROVAL OF THE USE OF SUCH COMMERCIAL PRODUCTS. 


\section{FOREWORD}

This report is based on a thesil prepared by Mr. Robert $W$. Criap of the Concrete Divinion of the U. S. Army Engineer Waterraya Experiment Station (W:S) in partial fulfillment of the requirementa for the degree of Manter of Science in the Department of Civil Engineering, Mianatppi State University.

The inventigation was conducted at the Concrete Division, was, from June 1970 to September 1970. Kr. C. R. Hallford performed the petrographic analyain.

Directors of the during the conduct of the inventigation and the preparation and publication of this report rere COL Levi $\Lambda$. Brown, CE, and COL Ernest D. Peirotto, CE. Technical Director was Mir. F. R. Brown. 
LIST OF TLBTES . . . . . . . . . . . . . . . . . ix

LIST OF FIGURAS. . . . . . . . . . . . . . . . . . . xi

I. INTRODUCTION . . . . . . . . . . . . . . . . 1

Background. . . . . . . . . . . . . . . . 1

Provious Studion. . . . . . . . . . . . . 2

Objectives of This Investigation. . . . . . . . . 3

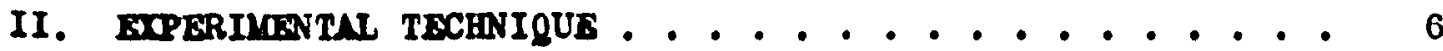

General ....................... 6

Petrographic Bramination. . . . . . . . . . . T

Specimen Preparation. . . . . . . . . . . 9

Bulk Denaity. . . . . . . . . . . . . . 14

Ultresonic Pulse Velocities... . . . . . . . 16

Static Arial Strens-Strain Measurementa . . . . . 18

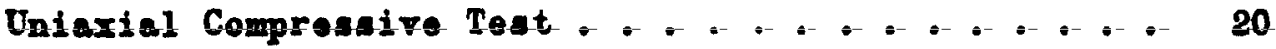

III. PRESNTLTION AND DISCUSSION OF RISLITS . . . . . . . . . 24

General .............. . . . . . 24

Diacuseion of Correlations. . . . . . . . . . . 35

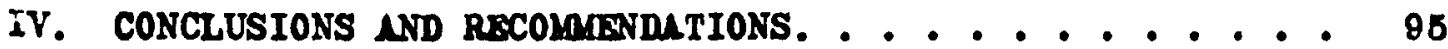

Concluaiona . . . . . . . . . . . . . . . 86

Recomendations.................. . . 87

v. ABSTR . . . . . . . . . . . . . . . . . 99

VI. APPENDICES - . . . . . . . . . . . . . . 103 


\section{TABLE OF CONTEN'TS-Continued}

Chapter

Page

Appendix I--Petrographic Descriptions. . . . . . 103

Appendix II-Table of Critical Valuen . . . . . 115

VII. BIBLIOGRUPHY. . . . . . . . . . . . 117 


\section{LIST OF TABLES}

Tables

1. Phyaical Property Tent Resulta., . . . . . . . . 25

2. Computed UItrasonic Propertien. . . . . . . . . . . . 29

3. Correlation Coefficients Obtained for Variour Paira of Rock Properties... . . . . . . . . . . . 47 
LIST OF FICHRES

Figure

Page

1. Diamond Blade Slab Saw. . . . . . . . . . . . 11

2. Vise-Type Specimen Carriage for Diamond Blade SIab

Sar . . . . . . . . . . . . . . . . 12

3. HJdraulic Surface Grinder . . . . . . . . . . . 13

4. Pycnometer Chamber. . . . . . . . . . . . . 15

5. Equipment for Measuring Ultranonic Pulse Velocitien.. 17

6. Typical Photographe of Ultranonic Wave-Forme as

Displajed on Hewlett-Packard Oscillosoope... . . 18

7. Moseloy Lutograf, $x-y$ Recorder and Other Strena-

Strain Racording Equipment. . . . . . . . . . 21

8. Baldwin 440,000-pound Universal Testing Machine . . . 23

9. Typical Fallures of Rock Cores in Uniaxial

Comprearion . . . . . . . . . . . . . . 33

10. Sierra Nevada Batholith Tonalite - Plot of Ultimate

Uniaxial Compresaive Strength $\left(C_{0}\right)$ Veraue

Ultramonic Compresaional Pulse VelocitJ $\left(V_{p}\right)$. . . 38

11. Tonalite - Plot of Ultimate Uniarial Compreasive

Strength $\left(C_{0}\right)$ Versua Ultrasonic Compressional Pulse

Velocity $\left(\mathbf{v}_{\mathrm{p}}\right) \cdot . \cdot . \cdot . \cdot . \cdot . \cdot . \cdot . \cdot . \cdot . \cdot 39$

12. Granite - Plot of Ultimate Uniarial Compreasive

Strength $\left(C_{0}\right)$ Veraue U1trasonic Comprenaionel Pulae

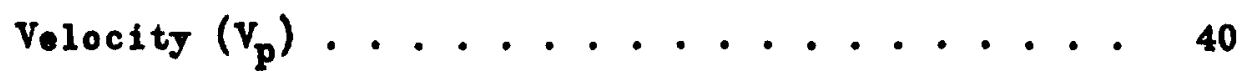


LIST OF FIGHRES-Continued

Figure

13. Granite and Tonalite - Plot of Ultimate Uniarial

Compressive Strength $\left(C_{0}\right)$ Versus Ultranonic

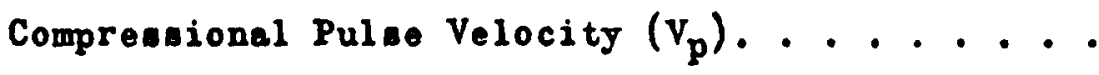

14. Sierra Nerada Batholith Tonalite - Plot of Ultimate

Uniaxial Compresaive Strength $\left(C_{0}\right)$ Verous

Ultrasonic Shoar Pulse Velocity $\left(V_{\text {m }}\right)$. . . . . .

15. Tonalite - Plot of Ultimate Uniaxial Compreasive

Strength $\left(C_{0}\right)$ Versus Ultrasonic Shear Pulse

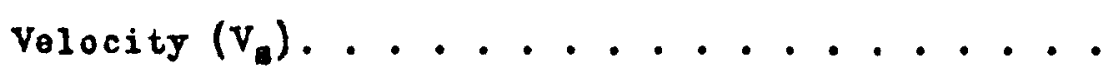

16. Granite - Plot of Ultimate Uniaxial Compresaive

Strength $\left(C_{0}\right)$ Verwu Ultrasonic Shear Pulae

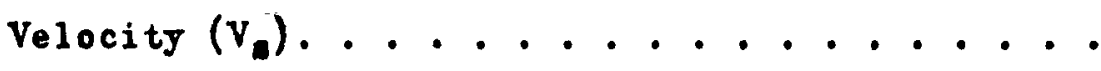

17. Granite and Tonalite - Plot of Ultimate Uniaxial

Compressive Strength $\left(C_{0}\right)$ Veraus Ultranonic Shear

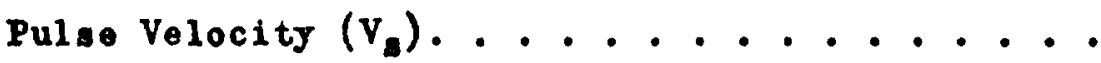

18. Sierra Nevada Batholith Tonalite - Plot of Ultimate

Uniaxial Compreasive Strength $\left(C_{0}\right)$ Vermü

Ultrasonic Young' Modulu* (Edyn $). . . . . . .$.

19. Tonalite - Plot of U1 timate Uniaxial Compreasive

Strength $\left(C_{0}\right)$ Versus Ultrasonic Young'

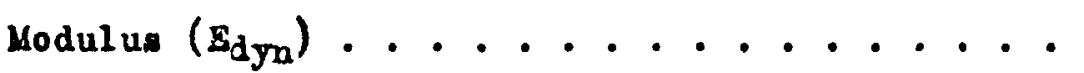

20. Granite - Plot of Ultimate Uniaxial Comprenaive

Strength $\left(C_{0}\right)$ Verous Ultrasonic Young'

Modulus $\left(\mathrm{E}_{\mathrm{d} J \mathrm{O}}\right)$. . . . . . . . . . . . . 


\section{LIST OF FIGURA-Continued}

Figure

Page

21. Granite and Tonalito - Plot of Ultimate Unieriel

Compreseive Strength $\left(C_{0}\right)$ Veraus Ultrasonic

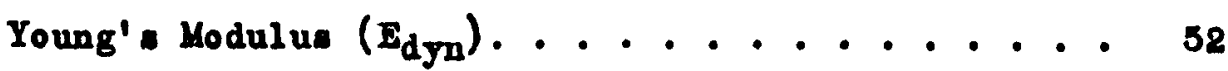

22. Sierra Nerada Batholith Tonalite - Plot of Ultimate

Uniaxial Compreanive Strength $\left(C_{0}\right)$ Verous

Ul trasonic Shoar Modulua $\left(G_{d y n}\right) . . . . . . . . .63$

23. Tonalite - Plot of Ul timate Uniaxial Compresaire

Strength $\left(c_{0}\right)$ Veraus Ultrasonic Shear Modulue

$\left(\mathrm{G}_{\mathrm{dyn}}\right) \cdot \cdot \cdot \cdot \cdot \cdot \cdot \cdot \cdot \cdot \cdot \cdot \cdot \cdot \cdot \cdot \cdot \cdot \cdot \cdot \cdot$

24. Granite - Plot of U1timate Uniaxial Compreanive

Strength $\left(C_{0}\right)$ Versue Ultranonic Shear Modulue

$\left(G_{\mathrm{dyn}}\right) \cdot \cdot \cdot \cdot \cdot \cdot \cdot \cdot \cdot \cdot \cdot \cdot \cdot \cdot \cdot \cdot \cdot \cdot \cdot \cdot \cdot \cdot$

23. Granite and Tonalite - Plot of Ultimate Uniaxial

Compreseive Strength $\left(C_{0}\right)$ Versue Ul trasonic Shear

Modulus $\left(G_{d y n}\right) \cdot . \cdot . \cdot . \cdot . \cdot . \cdot . \cdot . \cdot . \cdot .56$

26. Sierre Nerada Batholith Tonalite - Plot of Ultimate

Uniaxial Compreanive Strongth $\left(C_{0}\right)$ Veraus

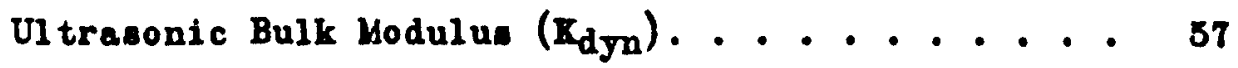

27. Tonalite - Plot of Ultimate Uniaxial Compresaive

Strength $\left(C_{0}\right)$ Versus Ultrasonic Bulk Modulue

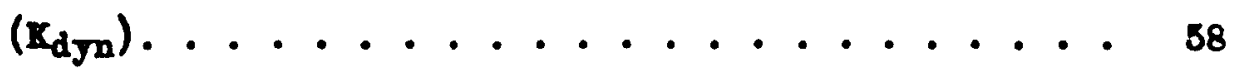

28. Granite - Plot of UItimate Uniaxial Compreasive

Strongth $\left(c_{0}\right)$ Verau Ultranonic Bulk Lodulua

$\left(\mathrm{x}_{\mathrm{d} \mathbf{n}}\right) \cdot . \cdot \cdot \cdot \cdot \cdot \cdot \cdot \cdot \cdot \cdot \cdot \cdot \cdot \cdot \cdot \cdot \cdot \cdot \cdot \cdot \cdot 59$ 
29. Granite and Tonalite - Plot of Ultimate Uniaxial

Compressive Strength $\left(C_{0}\right)$ Versua U1trasonic Bulk Modulus $\left(K_{d y n}\right)$

30. Sierra Nerada Batholith Tonalite - Plot of Ultimate

Uniaxial Compressive Strength $\left(C_{0}\right)$ Versus

Ultrasonic Poisaon's Ratio ( $\left.v_{\text {dynn }}\right)$. . . . . . . 63

31. Tonalite - Plot of Ul timate Uniaxial Compressive

Strength $\left(C_{0}\right)$ Versus Ultrasouic Poisson's Ratio

$\left(v_{\mathrm{djn}}\right) \cdot \cdot \cdot \cdot \cdot \cdot \cdot \cdot \cdot \cdot \cdot \cdot \cdot \cdot \cdot \cdot \cdot \cdot \cdot \cdot \cdot \cdot \cdot$

32. Granite - Plot of UItimate Uniaxial Compressive

Strength ( $c_{0}$ ) Verau Ultrasonic Poisoon's Fatio

$\left(\nu_{\mathrm{dyn}}\right) \cdot . \cdot \cdot \cdot \cdot \cdot \cdot \cdot \cdot \cdot \cdot \cdot \cdot \cdot \cdot \cdot \cdot \cdot \cdot \cdot$

33. Granite and Tonalite - Plot of Ultimate Uniaxial

Compresaive Strength $\left(C_{0}\right)$ Versus Ultrasonic

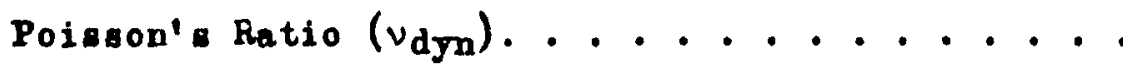
66

34. Sierra Nerada Batholith Tonalite - Plot of Static

Young' diodulus $\left(E_{\text {tan }}\right)$ Versus Ultrasonic

Compresional Pulae Velocity $\left(v_{p}\right)$. . . . . . 67

35. Tonalite - Plot of Static Young's Modulus (Etan

Veraue Ultrasonic Compresaional Pulae Velocity

$\left(v_{p}\right) \ldots . . \cdot \cdot \cdot \cdot \cdot \cdot \cdot \cdot \cdot \cdot \cdot \cdot \cdot \cdot \cdot \cdot \cdot \cdot \cdot \cdot \cdot$

36. Granite - Plot of Static Young's Modulue (Etan)

Versus Ultrasonic Compressional Pulse Velocity

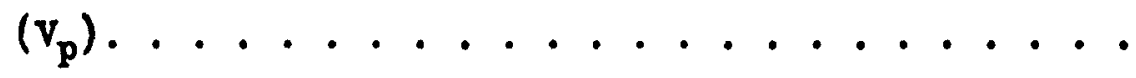


37. Granite and Tonalite - Plot of Static Young' *

Modulus ( $E_{\text {tan }}$ ) Versus Ultrasonic Compressional

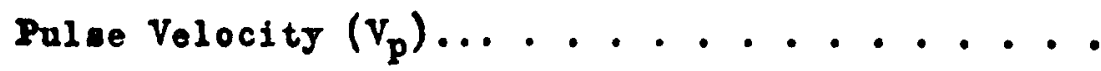

38. Sierra Nerada Batholith Tonalite - Plot of Static

Young' Hodulus $\left(E_{\text {tan }}\right)$ Versus Ultrasonic Shear

Pulne Velocity $\left(v_{\text {s }}\right)$. . . . . . . . . . . .

39. Tonalite - Plot of Static Young' Modulus (Etan)

Veroue Ultrasonic Shoar Pulse Velocity $\left(V_{p}\right)$. . .

40. Granite - Plot of Static Young' \& Modulu (Etan)

Veraua Ultranonic Shear Pulse Velocity $\left(V_{p}\right) .$. .

41. Granite and Tonalito - Plot of Static Young'a

Modulus ( $\left.\mathbf{E}_{\text {tan }}\right)$ Versua Ultrasonic Shear Pulae

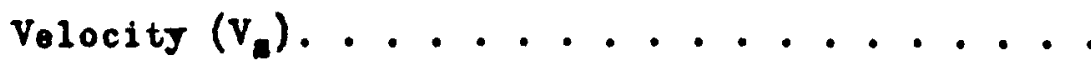

48. Sierra Nerada Batholith Tonalite - Plot of Static

Young' : Modulua $\left(E_{\text {tan }}\right)$ Versue U1trasonic Young'

Modulun $\left(\mathbf{E}_{\mathrm{dyn}}\right)$. . . . . . . . . . . . .

43. Tonalite - Plot of Static Young' Modulun ( tan $_{\text {(an }}$ )

Vermue Ultrasonic Young' Modulus $\left(\mathrm{F}_{\mathrm{d} \mathrm{j}_{\mathrm{n}}}\right) . . .$.

44. Granite - Plot of Static Young' Modulua ( tan $_{\text {tan }}$ )

Versua Ultramonic Young' Modulua $\left(E_{\mathrm{dyn}}\right)$.....

45. Granite and Tonalite - Plot of Static Young'

Kodulus $\left(E_{\text {tan }}\right)$ Versus Ultrasonic Young' Modulus

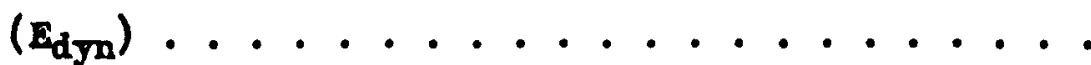




\section{IST OF FIGURES-Continued}

Figure

46. Sierra Nerada Batholith Tonalite - Plot of Static

Young's Modulus ( $\left.E_{\text {tan }}\right)$ Veraus Ultrasonic Shear

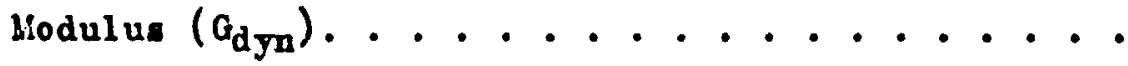

47. Tonalite - Plot of Static Young' Modulus ( Etan $_{\text {tan }}$ )

Versus Ultrasonic Shear Nodulua $\left(G_{d j n}\right) . . . .$.

48. Granite - Plot of Static Young's Modulus (Etan)

Versus Ultrasonic Shear Modulus $\left(G_{\text {dyn }}\right) . . . . .$. 83

49. Granite and Tonalite - Plot of Static Young's Modulua

(Etan $)$ Versus Ultresonic Shear Hodulus $\left(G_{d y n}\right)$.. 84

50. Sierra Nevada Batholitb Tonalite - Plot of Static

Young's Modulus ( $E_{\text {tan }}$ ) Versur Ultrasonic Bulk

Kodulus $\left(\mathrm{K}_{\mathrm{dyn}}\right)$. . . . . . . . . . . . .

51. Tonalite - Plot of Static Young's Lodulus ( $\left.E_{\text {tan }}\right)$

Versug Ultrasonic Bulk Modulue $\left(\mathrm{K}_{\mathrm{dyn}}\right) . . . .$.

52. Granite - Plot of Static Young's Modulue ( $E_{\text {tan }}$ )

Versur Ultrasonic Bulk Modulus ( $\left.\mathrm{K}_{\text {dyn }}\right)$. . . . . 87

53. Granite and Tonalite - Plot of Static Young' Modulua

$\left(E_{\text {tan }}\right)$ Verau Ultrasonic Bulk Modulua $\left(\mathrm{K}_{\mathrm{dyn}_{\mathrm{n}}}\right) .$. 88

54. Sierra Nevada Batbolith Tonalite- Plot of Static

Young' dodulus (Etan $)$ Versus Ultrasonic Poismon's

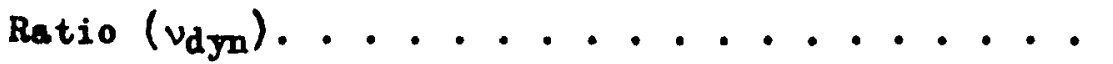

55. Tonalite - Plot of Static Young' Modulue ( $\mathbf{E}_{\text {tan }}$ )

Versus Ultrasonic Poiseon's Ratio $\left(v_{\mathrm{d} y \mathrm{~m}}\right) . . .$. . 


\section{LIST OF FIGURBS-Continned}

Figure

Page

56. Cranite - Plot of Static Young' Modulue (Etan)

Veraue Ultrasonic Poinaon' Ratio $\left(v_{\mathrm{d} y n}\right) . . . . . .93$

57. Granite and Tonalite - Plot of Stetic Young' Modulua

$\left(E_{t a n}\right)$ Versus Ultrasonic Poisaon' Ratio $\left(v_{d_{y n}}\right) \cdot .94$ 
CENPTER 1

\section{INTRODUCTION}

\section{Background}

Bfforts exerted over the pant neveral jeara to develop techniquen and etendarde to allow for the competent design and conitruction of engineering atructurea in rock hare led to the entablinhment of neveral particular mechanical rock properties in positiona of prominence. Lccording to Obert $(\theta) *$, these "mont importent phjaical properties for dentge purposen are denaity, Young'- noduiva, compressive strength, and flezural etrength."

The deternination of auch phyaical propertien, accompliahed through laboratory testing of samples of rock core and field tenting of portions of the in-aitu rock mans, is, an a rule, quite time consuming and expenaive. It if for this reason that correlation of phyoical properties of rock, and predictions of one propertJ from an alreadj determined value of another propertj, whould be tremendous asseta, provided the quality of the correlatione if auch that the - lement of doubt regarding test resulti and predicted properties is not of a magnitude necenditating an increase in the factor of safety.

One particuler aituation in wich auch correlatione rould prove of ralue aight be the aite evaluation and selection program.

* Number in parenthesis refer to references in the Bibliography. 
As Buming cereral sites rere being considered for a particular otructural endeavor, preliminary elimination might well be facilitated if one or tro of the less time consuming and less expenaive phyaical testa would jield data from which one could reasonably predict other, more difficult to determine, phyaicel properties to be used in the eraluation and elimination process. It is also posaible that correlations ach an these, if of sufficient quality, rould allor for reduction in the variety of tenta required to determine the physical properties now deemed necessary for competent deaign and conntruction in rock media.

Another aignificant application of phyaical property correlations might be the elimination of nome destructive physical testing, to be replaced by nondestructive testing. ss indicated by Obert (8), nondertructive teata can be repeated a numer of timen on the same apecimens, facilitating determination of and compenation for procedural and instrument errors. This rould allow one to aparate the variations due to instrument error from the variation due to actual differences in mechenical properties of the apecimens tested.

\section{Previous Studies}

In the past, laboratory investigations and correlations of phyaical propertien of rock have generally been limited to intact apecimens, 1.e., rock coren which are mecroscopically homogeneous and free of discontinuities auch an weans, jointa, fractures, and inclusions. However, even when these investigations have been restricted to intact rock, thus eliminating the highly variable fracture 
parameter, date plot: hare froquentlj been highly acattered in nature reaulting in correlations of quentionable value.

Unally, inveatigatione of this neture have encompansed many rock type (3) (4) (6) (7), the determined phyaical propertien for all rock types being lumped together and anolyzed in mans. This procedure in oriented torard determining general relationship characteristic of the entire group of apecimen. examined. But the implication here, namely that large variationa in mineral componition, geologic hiatory, and grain nize (which uavally enter into the classification of rock materiala) bare 1ittle or no effect on the relationahipa betreen phyaical properties, is dubious (10).

Thus, a definite neod exiots to investigate the relationships between various rock properties, focusing attention on individual rock types in an attempt to reduce the number of variablea and eliminate nome of the scatter tjpical of previou invetigations. Hopefully, the resulting correlations will be of a quality which will allow for the elimination of repotitive testing and data reduction, faciliteting more economic denign of engineering atructures.

\section{Objectires of This Inveatigation}

This atudy will be pricorily directed torard dotermining the influence of variation in rock type on the quality of correlation. obtained through linear correlation analjaia of rariou phyatcal rock properties. An attempt will also be made to deternine the effect of variation in grain aize within a particular rock type on the nature of the correlation between phyacal properties determined for apecimene of this rock tjpe. 
Specimen: of tonalite and granite will be prepared and tested, the following physical properties being determined:
(a) density
(b) compreseional pulse velocity
(c) whear pulse velocity
(d) Young' modulus of elasticity (static)
(e) ultimate uniaxial compreasive otrength.

Pulse velocitien will be determined according to the ASTM proposed Standard Method of Test for Laboratory Determination of Ultrasonic Pulae Velocitien and Elantic Conntante of Rock. Ultranonic elastic constants will be computed from propertien 1, 2 , and 3 . Static Young' modulus $w^{\prime} 11$ be computed from strens-etrain curven determined during uniaxial compresaive tents. Representative mpecimen will be aubjected to potrographic examination (x-ras diffraction analyein, modal analysic, etc.). In as far as is posaible, tho opecimens of tonalite and granite vill represent amples of rarious grain aizea, and mineral composition will be varied within the linits of the clasaification syatem (11). All opecimen will be intact, 1.e., free of macroscopic discontinuities ouch as fractures, joints, seana, and vesicles.

The date accumulated will be grouped and analjzed according to rock type, and then, for comparative purposea, analyzed in maan. Correlationa will be made between various paira of the phyaical propertien determined. In particular, ultimate uniaxial compreasive atrength and atatic Young' modulua will each be correlated with ultrasonic pul ve velocities and the rarious ultranonic elantic conatanta. Compariaons will be made of the quality of correlations ob- 
tained from the data grouped according to rock type and from the data treated in thoir ontirety, and an effort mode to deternine the influence of date analyain by rock type on quelity of the correlation. obtained.

Correletione will be made uning physical propertien deternined for three groups of epecimens within one particular rock type (tonalite). These throe group will be escentially of the same mineral composition and geologic hiatory, the rariable being grain -ize. The intention will be to evaluate the contribution of varietion in grain aize to the nature of the phyaical property correlation obtained within the particular rock type. 


\section{CHAPTER 2}

\section{ETPERIMENTAL TECHNIQUE}

\section{General}

Seventy-nine samples of rock core representing two rock types (granite and tonalite) were prepared and tested in the course of this investigetion. The epecimens rere remored from 10 drill aites in six geographic localities. Generally, eight apecimens of one particular rock type, either granite or tonalite, rere selected from the core from each of the drill sites. All specimens tested rere intact (contained no macroscopic joints or fractures) and easentially homogeneous NX-size (nominal 2-1/8-inch diameter) cylindrical corea.

Testo were conducted during this investigation to determine the following:

(a) rock type and mineral composition

(b) bulk density

(c) ultrasonic pulse velocities (compressional and shear)

(d) ultimate uniarial compresaive otrength

(e) atatic stress-strain relations.

Ul trasonic elastic constants were computed from measured ultrasonic pulse velocities and specific gravities. Static Young' moduli rere determined from the axial stress-strain relations observed and recorded during the uniaxial compreasive tests. 
One representative pecimen from each of the 10 groupe $(10 \mathrm{drill}$ niten) ras selected for limited petrographic examination. These specimens were arred axially, one sared aurface of each mpecimen being polished and photographed at normal wize.

Composite samples rere taken from the remaining portions of the selected apecimens, and ground into a fine powder wo as to pass a No. 325 aieve $(44 \mu)$. X-ray diffraction patterno rere made of each sample. These pattern vere then examined to make mineralogical identifications and comparisons. Smail portions of each of these pordered samplen were tested in dilute hydrochloric (HC1) acid and with a magnetized needle to detect the presence of carbonate minerals and megnetic minerals, respectively. All X-ray patterns were made with an XRD-5 diffractometer uning nickel-filtered cooper radiation.

Thin sections were prepared from each apecimen and examined with a Sencer polarizing microscope. A point-count modal analyais was made on each thin section to determine the mineral composition by percent and grain size (13) of each of the rocks represented. The number of counts per section ras held constant (500), but spacing of the counter ras varied with grain size in an attempt to obtain a representative statistical arerage (2).

A summary of the results of the petrographic examination of representative sample from each of the 10 groups of core is given below. Detailed result are given in sppendix 1.

(a) Tonalite (Vermilion granite formation, Minnesota). Brownishgray, medium- to coarse-grained. Sections were masaive and 
unweathered. Biotite ras broken and altered to chlorite. Microcline was unaltered and unbroken. Very few microfracturen were detected.

(b) Granite (Lucerne Pluton, Maine). Black and white. Coaraegrained porphyritic texture. Biotite ras unaltered. Plagioclase was alightly altered to sericite. Specimens were unweathered and contained very fer microfractures.

(c) Granite (Granite Nountains Uplift, Wyoming). Unweathered, brownin-gray, coarse-grained. Microcline was unaltered. Plagioclase was altered to sericite. Biotite was sightly altered to chlorite. dicrofractures rere somerhat common.

(d) Tonalite (Sierra Nevada Batholith, California). Fine-grained, dark colored rock. Sections were fresh and contained no macrofracturea. Contains principally plagioclase feldspar and biotite mica with amaller amounts of quartz and hornblende.

(e) Tonalite (Sierra Nevada Batholith, California). Medium- to coarae-grained igmeous rock. Section were fresh and intact. Similar in composition to fine-grained rock discussed above.

(f) Tonalite (Sierra Nevada Batholith, California). Mediumgrained igneous rock; much finer grained than medium- to coarsograined tonalite (e). Similar in mineral composition to the tro tonalites discussed immediately before (d and e) except olightly more biotite and slightly lese hornblende. Also contains very small amounts of magnetite.

(g) Granite (Northwest of Lone Grove Fluton and Fnchanted Rock Batholith, Texas). Medium-grained, red granite. Sections rere 
Intact and anwoathered. Slight alteration of microcline and plagioclase. Yore muscovite mica present than biotite alca.
(b) Granite (Sherman Granite Facles of Southern Laranie Range, Woming). Coarae-grained, light-graj granite. No precrieting fracture nurfeces could be detectod. Largely componed of quartz, potanaium feldapar, plagioclase feldapar, and biotite, with lesser amounta of hornblende.

(i) Granite (Laramie Range, Wyoming). Medium- to coarne-grained, pink granite. Porphyritic texture. Sectiona rere macroscopically free of fractures and rere unreathered. Predominately componed of quartz, plagioclase feldepar, potaneium feldapar with lener amount. of hornblende biotite and chlorite.

(j) Tonelite (Coder City Tonalite, Utab). Medium-grained, gray tonalite. Conoisted primarily of plagioclase foldupar, quartz, and hornblende with lener amounte of potaneium feldepar, biotite, and magnetite. Biotite was alightly altered to chlorite.

\section{Specimen Proparation}

Test apecimens were prepared an auggented in the ASTM proposed "Standard Mothod of Tont for Onconfined Compreneive Strength of Rock Core Specimone" and Corps of Engineors Standard Method of Tent for Triaxial Strength of Undrained Rock Core Specimens (12), CRD-C 147. When proparod according to the above apecifications, opecimen tolorances were well within the 1 imite required by the $18 T$ proposed "Standard Method of Teat for Laboratory Determination of Ultranonic Pulao Velocitios and Elastic Constants of Rock. 
All mamples wore cut to lengths of approximately 4.32 inches with a Corington (Figure 1) alab saw (16-inch diameter diamond blade). Thin opecimen length ran melected in order to meet the apecified length to diameter ratio requiremente $(2.0 \leq \mathrm{L} / \mathrm{D} \leq 2.5)$. Since specimen diameter ranged from 2.06 to 2.16 inchen, probably due to variation in rock type, bit rear, and drilling technique, the actual length to diameter ratios also varied slightly, but rere in all casen greater than 2.0 and lese than 2.5 .

During the cutting process, specimens rere secured in a vise (Figure 2) which aided in alignment and provided for cutting aurfaces nearly perpendicular to the axis of the core. A molution of rater and soluble oil ras used as blade lubricant and coolant. All mpecimens were thoroughly washed immediately absequent to cutting to remove any solution which might adhere to the specimen aurface. Feed rate was adjusted such that one cut acrose a diameter required approximately 15 minutes.

After cutting, the ond of all specimens were ground amooth, parallel to each other, and perpendicular to the axis of the core with a Norton hydraulic surface grinder (Figure 3). This surface finishing ras puraued in auch a manner that apecimen ondo were flat to within 0.001 inches and did not depart from perpendicularity to the axis of the core by more than the allorable 0.01 inch in 2 inches ( 0.25 degrees). Subsequent to grinding, the opecimens rere again thoroughly washed to remore any of the oil-rater grinding wheel coolant solution from the core surfaces. 


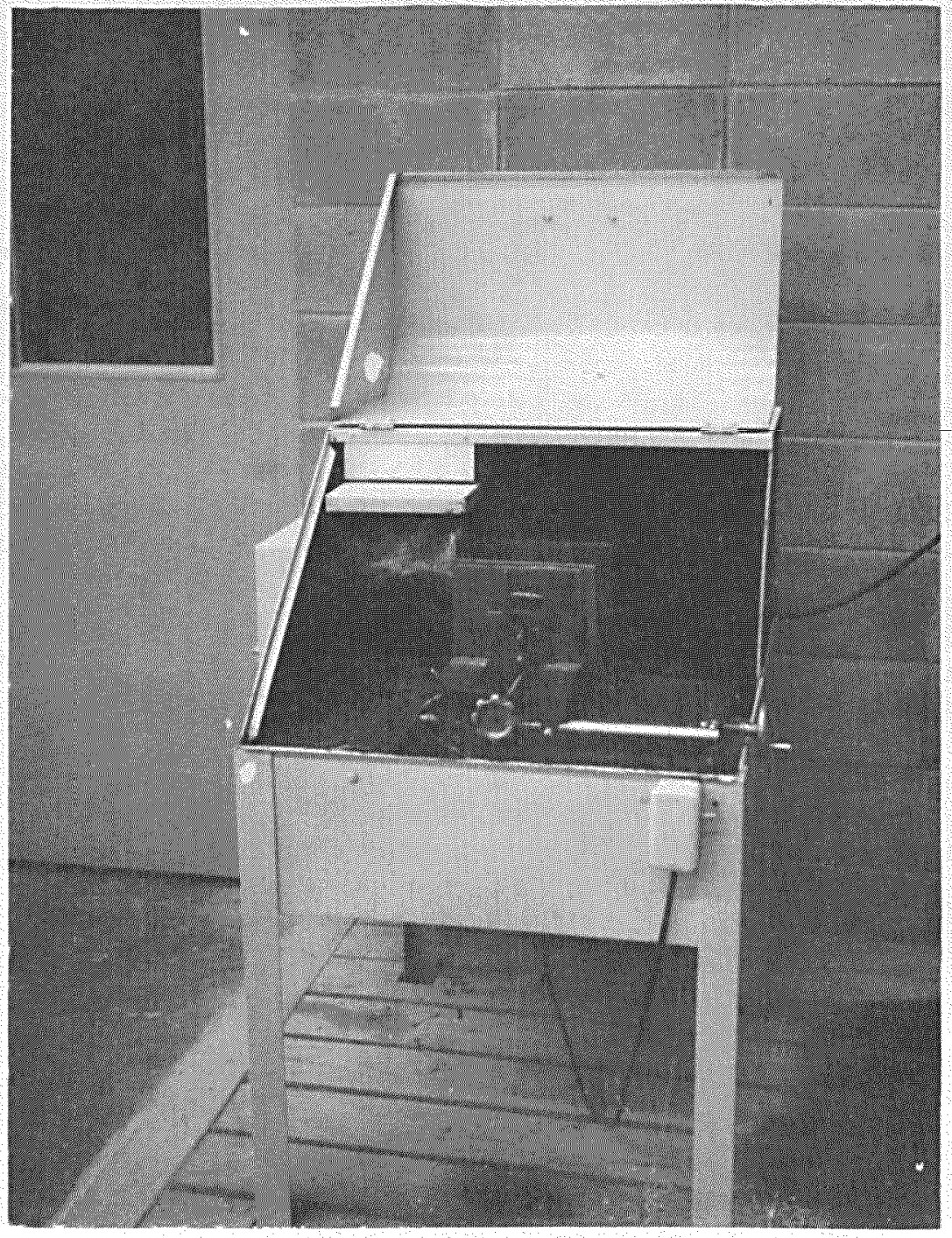

Figure 1. Diamond Blado Slab Saw. 


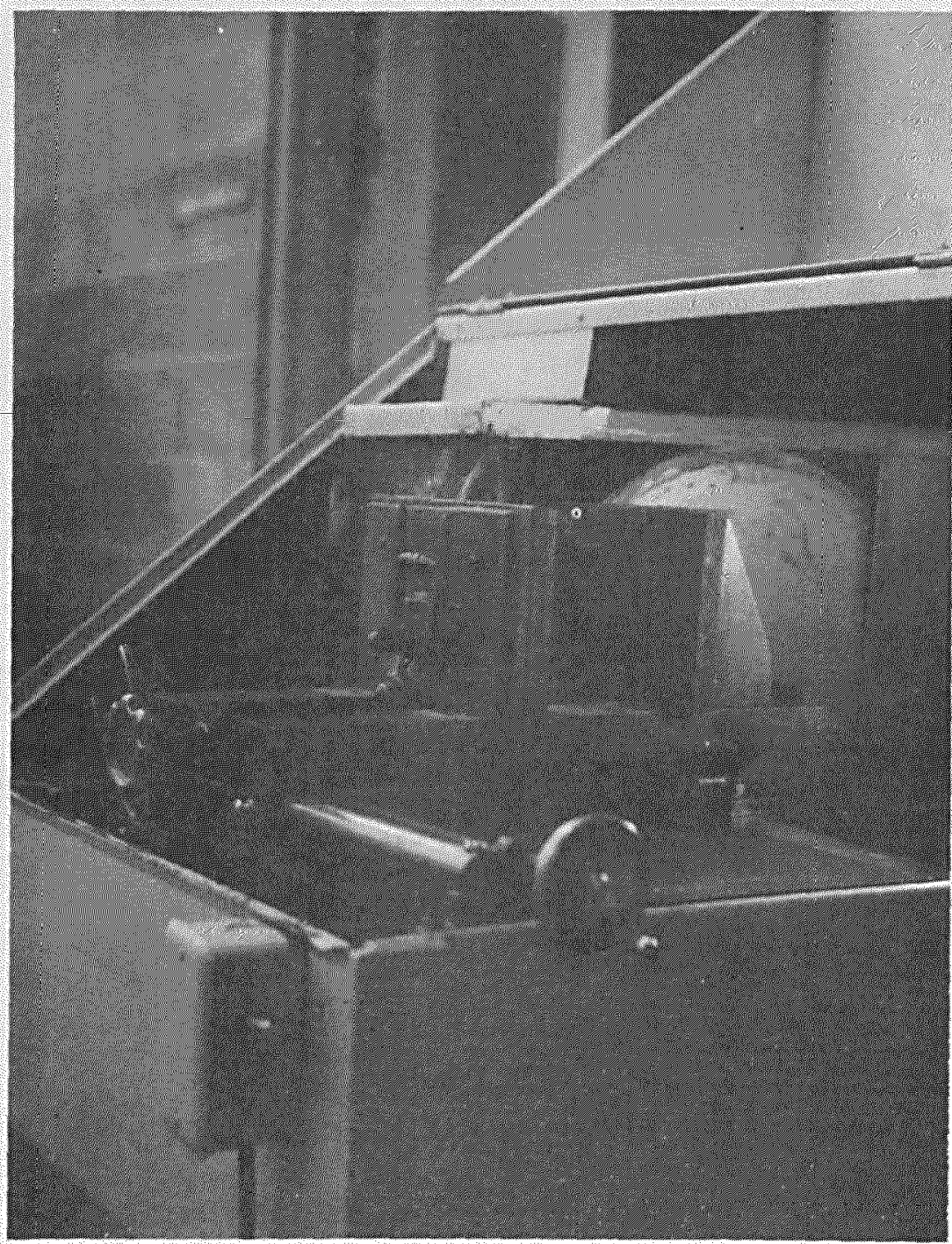

Figure 2. Vime-Type Spocieen Carriage For Diamond Blade Slab Sav. 


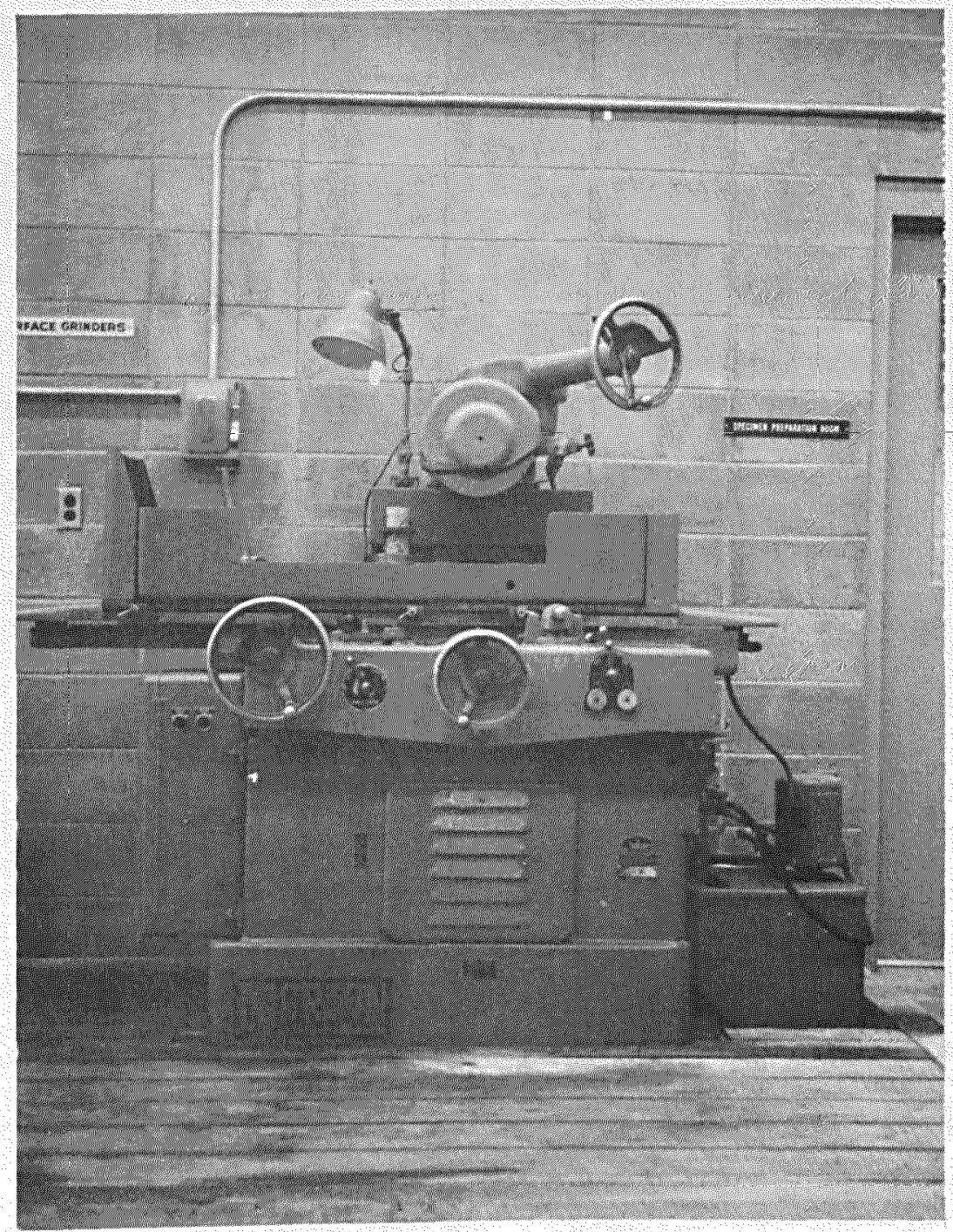

Figure 3. Hydraulic Surface Grinder. 


\section{Bulk Density}

Bulk densities rere determined according to U. S. Army Ingineer Waterway Experiment Station, Concrote Diviaion "T-2 Mothod of Deteraining Bulk Density of Rock Cores." The test procedure coninted of:

(a) wawh the core to remove dunt and other costings from the apecimen

(b) air dry the upecimen to constant woight, and reigh air-dried spectmen to nearest 0.1 gram

(c) determine volume of epecimen by liquid dimplecement in a pycnometer chamber (rigure 4) conteining distilled rater

(d) colculate the density of the core in the air-dried condition from the following formula:

$$
G_{0}=\frac{W_{0}}{V_{0}}
$$

where

$G_{0}=$ density of the air-dried core

$W_{0}=$ reight of the air-dried core in gram

$V_{0}=$ volume of the core in cubic centimeters.

Temperature of the dietilled water in the pycnometer chamber was taken into account when the rolumes of the specimena rere determined.

In this inveotigation, denatiea were computed from air-dried apecimens rather than oren-dried apecimens to aroid posaible changea in phyaical properties due to oven-drying as have been observod in several previous studies. Obert (9), noted that oven-drying often produced pronounced and omotimen drastic changes in elastic conotents, and that these changes rere frequently permanent. 


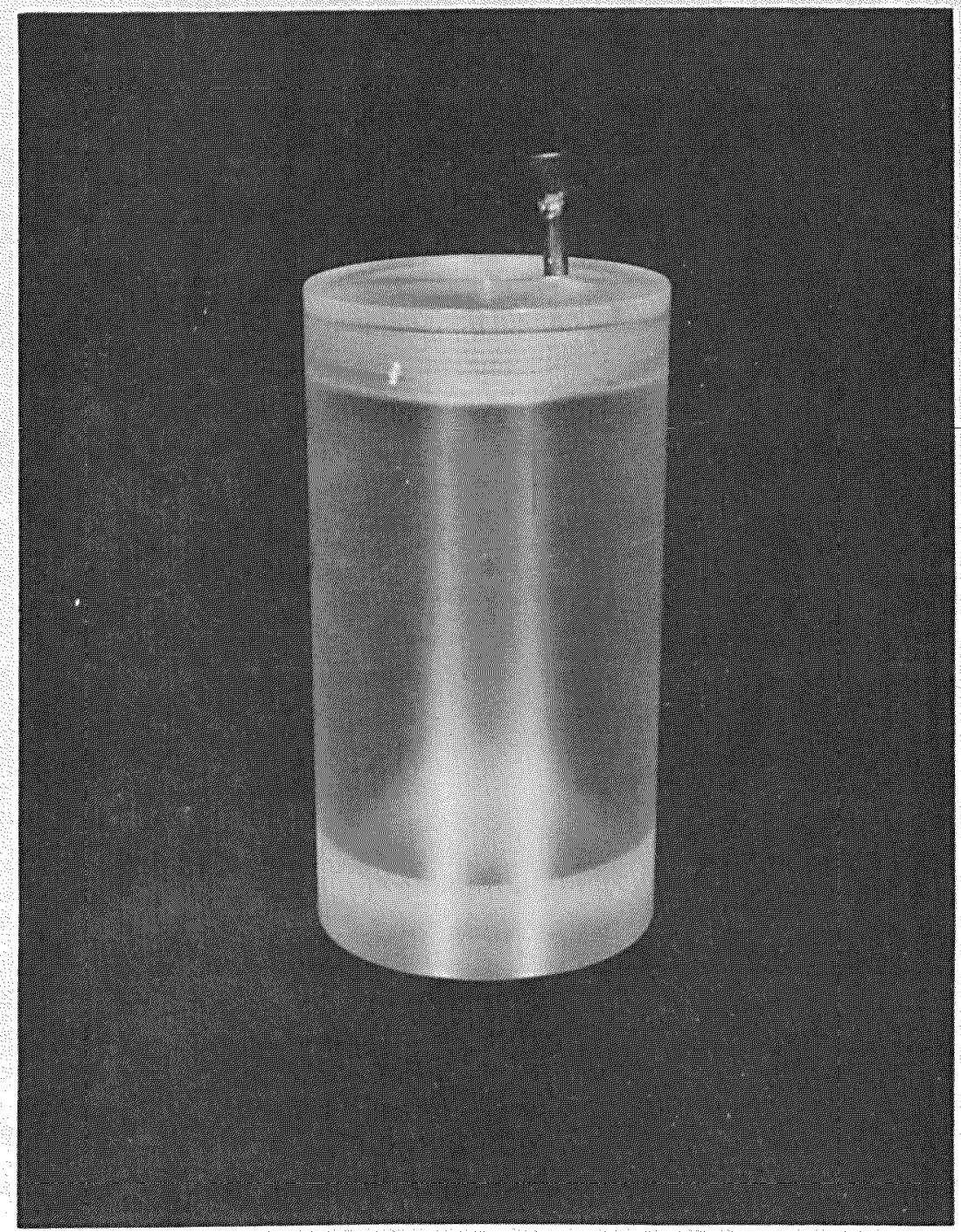

Flgure 4. Pycnometer Chamber. 


\section{Ultrasonic Pulse Velocitiea}

Ultrasonic pulwe velocities rere determined according to the ASTM proposed "Standard Method of Test for Laboratory Determination of Ultrasonic Pulse Velocities and Elastic Constant of Rock." This method is valid for determination of compressional and shear wave velocities in both iaotropic and anisotropic media.

Barium titanate cryotals and PZT-5A high capacitance leadzirconate-titanate cryatals were used to produce compressional and shear pulses, respectively. These pulses rere produced by applying short duration, high voltage pulses to the appropriate cryotals, resulting in compressional or shear pulses, whichever the case may be, being generated in the opecimen. The high voltage pulwes, when applied to the $X$-cut barium titanate cryatal, caused the crystal to expand and contract yielding compressional stress pulses, whicb were transmitted to one end of the specinen. When epplied to the Y-cut lead-zirconate-titanate crystal, the pulses caused the shear crjstal to vibrate in a direction perpendicular to the axis of the core creating shear pulses which rere transmitted to one end of the specimen. The arrival of the pulses at the other end of the specimen were noted by a companion crystal affixed to that end, which acted an a mechanical-olectrical transducer and generated equivalent electrical pulses. Pureline white petroleum jelly and phenyl salicylate were used respectively, between the compressional transducers and the rock specimens, and betreen the whear transducers and the rock specimens.

These electrical aignals were recorded on an oscilloncope (Figure 5) as stationary wave forms, which alloved rather accurate 


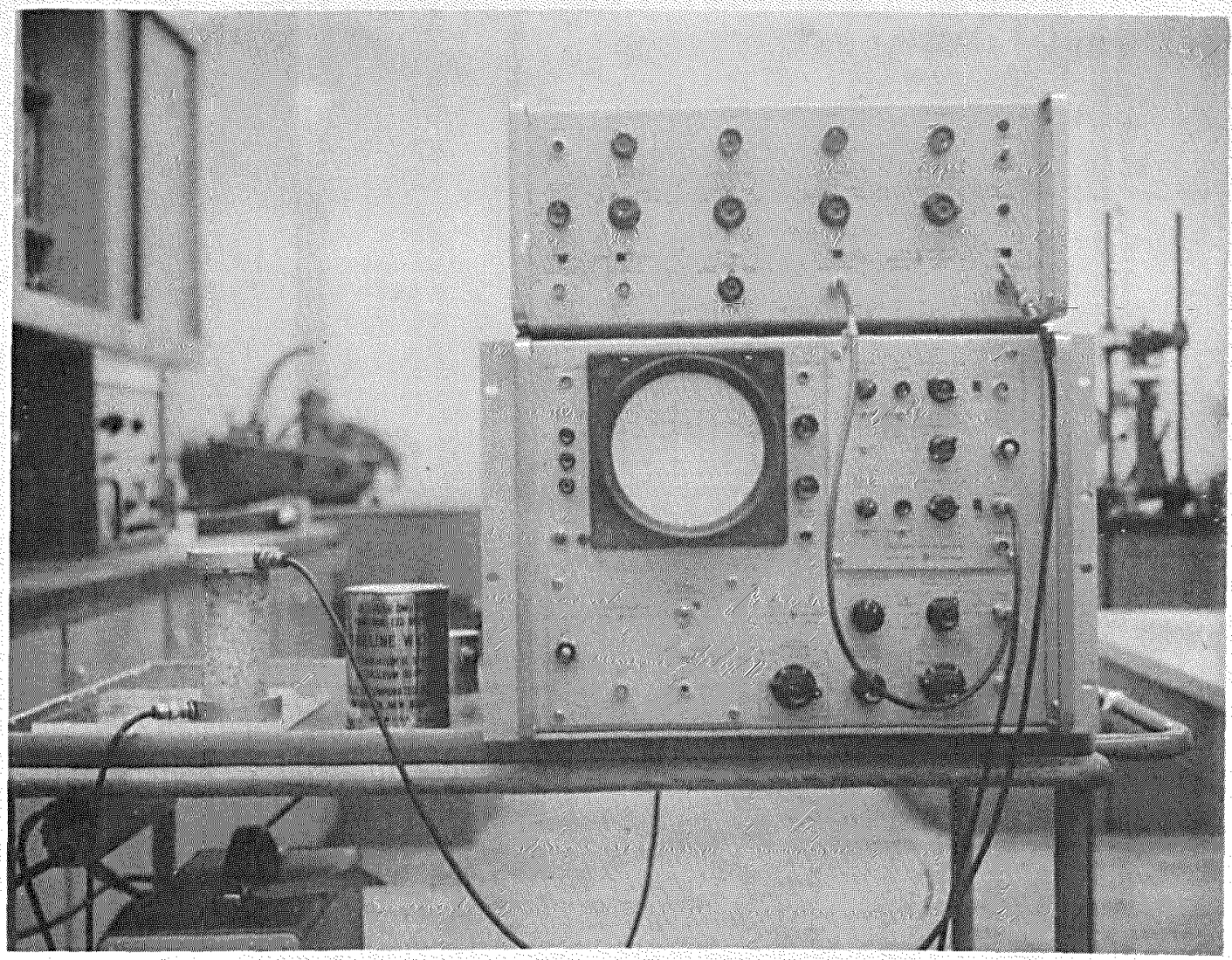

Figure B. Equipment For Hessuring U1trasonic Pulse Velocities. 
measurement of the time of travel of the puldes through the individual apecimena. Stationary rave forma, as diaplajod on a Perlett-Packard model 1780-A oscilloncope, rere photographed (Figure 6) and pulse trevel times read directly from the time marked photograph. These times were corrected to eliminate error due to pulse travel time through the tranaducer leade, tranaducere, and tranaducer-apecimen connection material. (petroleum jelly or phengl salicylate), thus, jielding pulse travel times through the rock core specimens above. Compresaional and shear volocitien rere then determined from

$$
v_{p}=\frac{t}{t_{p}} \text { and } v_{b}=\frac{I}{t_{B}}
$$

where

$V_{p}=$ compresaional pulse velocity

$V_{8}=$ abeer pulse relocity

$t_{p}=$ travel time of the compressional pulse through the specimen alone

$t_{\text {s }}=$ travel time of the shear pulse through the specimen alone

$I$ = length of the apecimen.

All comprosicional and shear pulso velocitien determined in this inventigetion rere measured with zero load on the opecimen.

\section{Static Axial Strece-Strain Measurements}

To determine axial tatic otreas-atrain rolations, BaldwinLima-Hamilton SR-4, Type A3-S-6, electrical reaistance strain gagea were affixed rertically to opposite idea of each apecimen. The gagea rere located in a manner such that the midpoint of the 


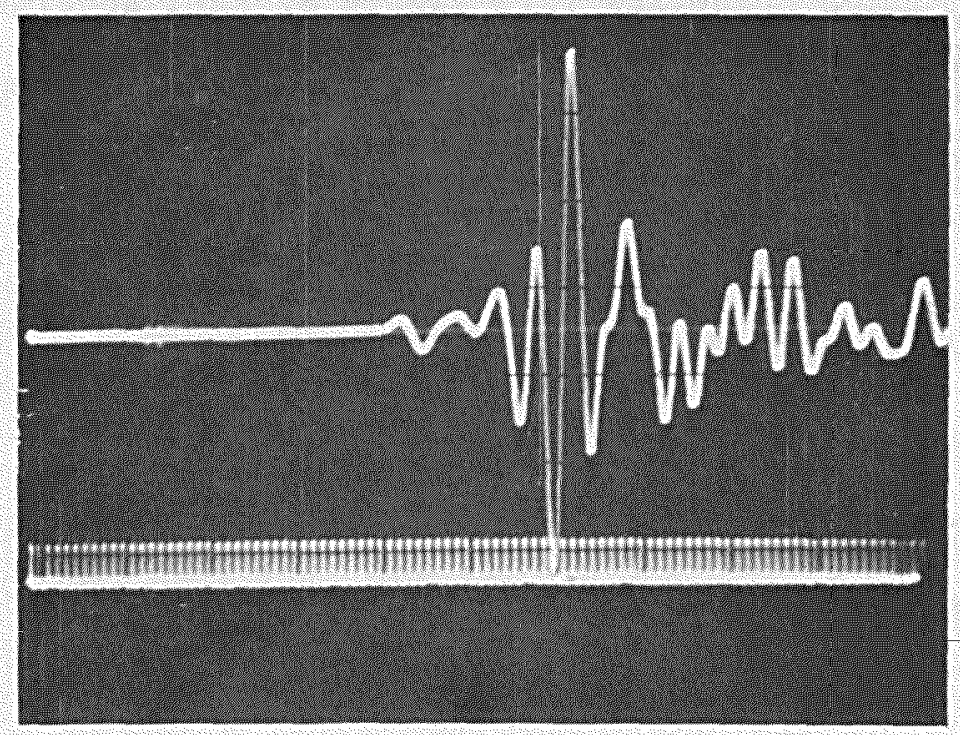

Shear Pulso

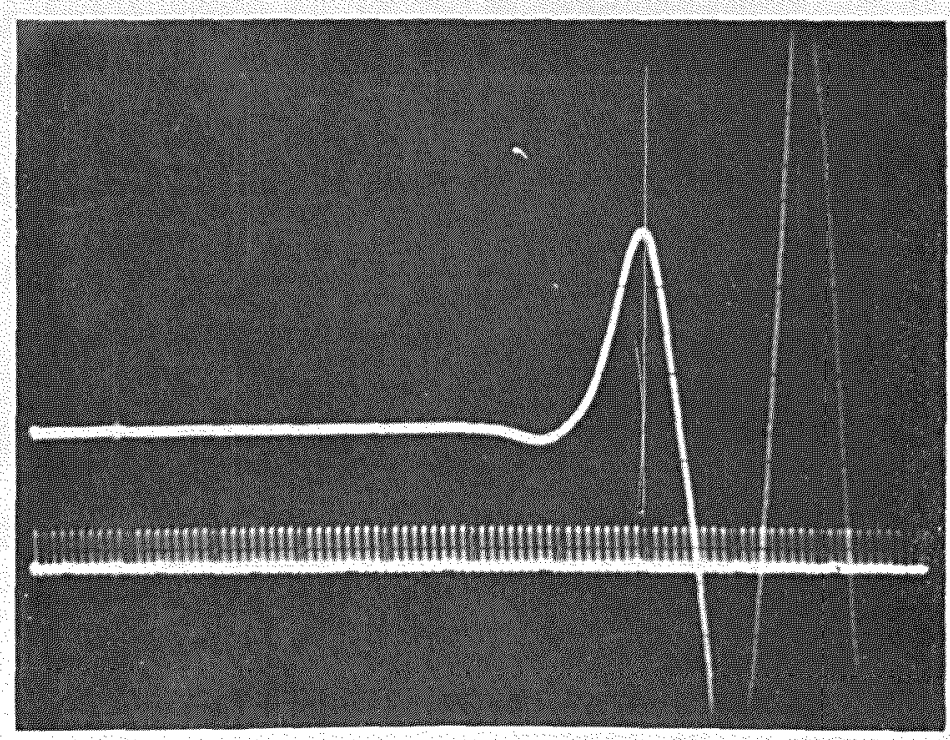

Comprestional Pulse

Figure 6. Typical Photograph of U1 tranonic Wave-Form As Diaplayed on Hewlett-Packard Oacilloscope. 
resistance wegment was at midheight of each mpecimen. The gage length was $13 / 16$ inches, such that no portion rould be effected bJ the nonuniform stross distributions noted by Fairhurst (5) to exist over the upper and lower $1 / 12$ length of each epecimen, $1.0 .$, the uppermost and lowermost $1 / 3$ to $1 / 2$ inches for all opecimens used in this sudy.

All gages rere bonded directly to the rock opecimen by using SR-4 cement, a fast drying nitro-cellulose cement manufactured by Baldrin-Lima-Hamilton for the expreas purpose of application of SR-4 bonded atrain gages. Prior to application of the cement, apecimen surfaces -rere cleaned to remore substances such os oil or dust which might impede derelopment of a secure bond between the apecimen and gage. A thin coat of cement was then applied both to the apecimen and to the gage, after which the gage was mounted under moderate presure and allowed to dry for 24 hours.

To determine otrens-strain relationa, the tro gages were wired In series resulting in an output of the average otrain regiotered by the two gages. Stress and strain were continuounly plotted during the uniaxial compreasive tent by uaing a Moseley Autograf $x-y$ recorder. A photograph of the recording equipment is given in Figure 7 .

\section{Uniexiel Compreasive Tent}

All opecimene rere subjected to static compresaive loading to determine axial ctresn-metrain relations, as previounly mentioned, and to determine ultimate uniaxial compresaive etrengthe. 


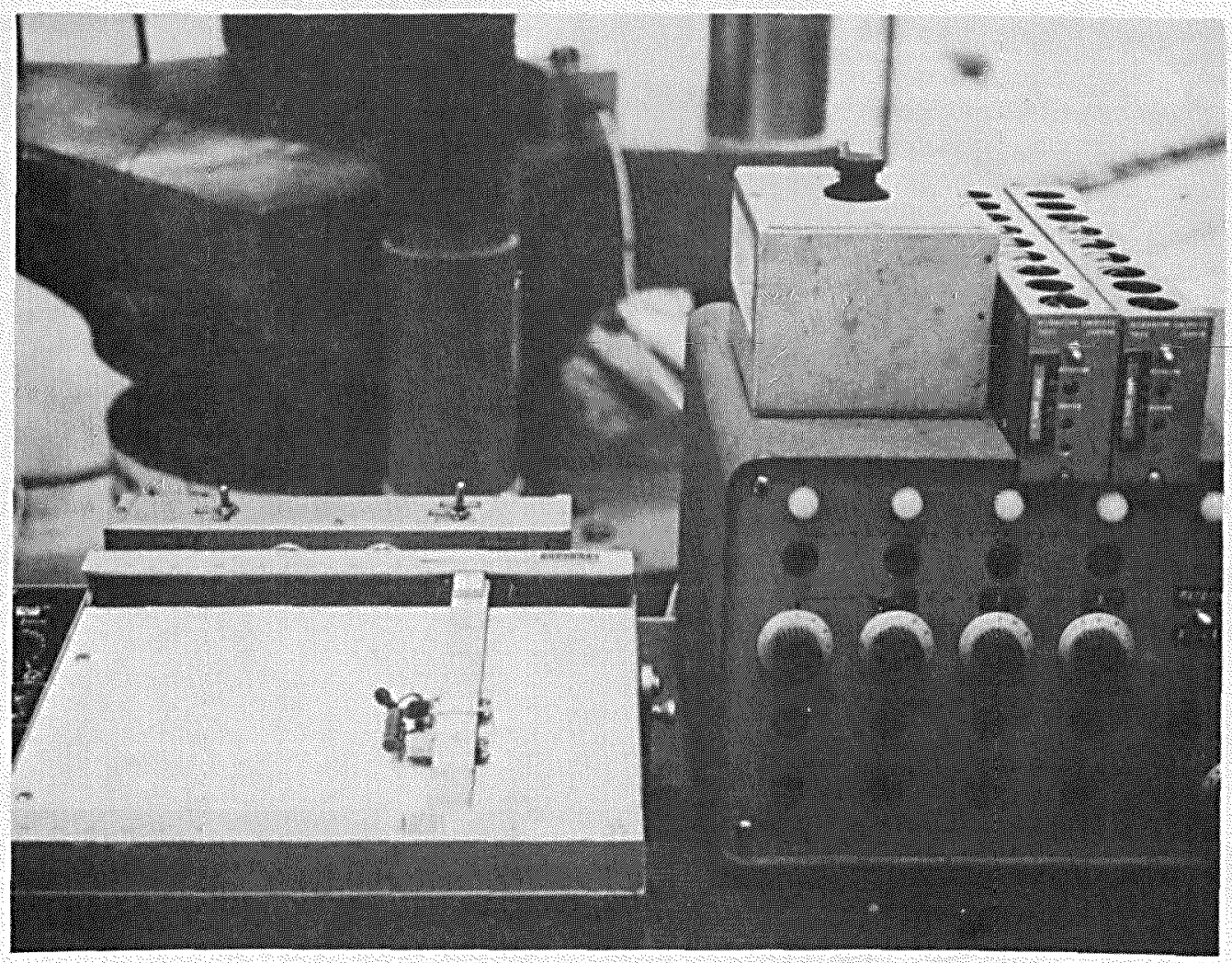

Figure 7. Moseley Autograf, $x-y$ Recorder and Other Strese-Strain Recording Equipment 
1 440,000-pound univeraal, Beldrin hydraulic testing machine was used for loading the pecimens. A photograph of this machine is given as Figure 8.

This tent was conducted according to the $1 S T M$ proposed Standard Method of Teat for Unconfined Compreneive Strength of Rock Core Specimen. All mecimen. were carefully aligned so that the axis of each core teated wes coincident with the center of thrust of the ophorically meated bearing block. An initial seating load of approximately 100-200 pounds was applied very alowly while the apherical seated bearing block ran adjusted. All tents rore conducted at a loeding rate of $35 \pm 15$ pai per second fconstant for particular apecimen) wo that catestrophic failure occurred within 5 to 15 minutes of comencement of loading. As noted by the proposed standard, wach a rate of load mould provide valuen of ultimate uniaxial comprentive trength which are relatively free from the effect of rapid loading.

Ultimate uniaxial compreasive strengthe rere calculated by dividing the maximum load carried by the apocimen during the teat by the average initial crom-nectional area of the apecimen determined as aggented in the ASTM proposed standard. 111 strength were expressed to the noarest $10 \mathrm{pmi}$. 


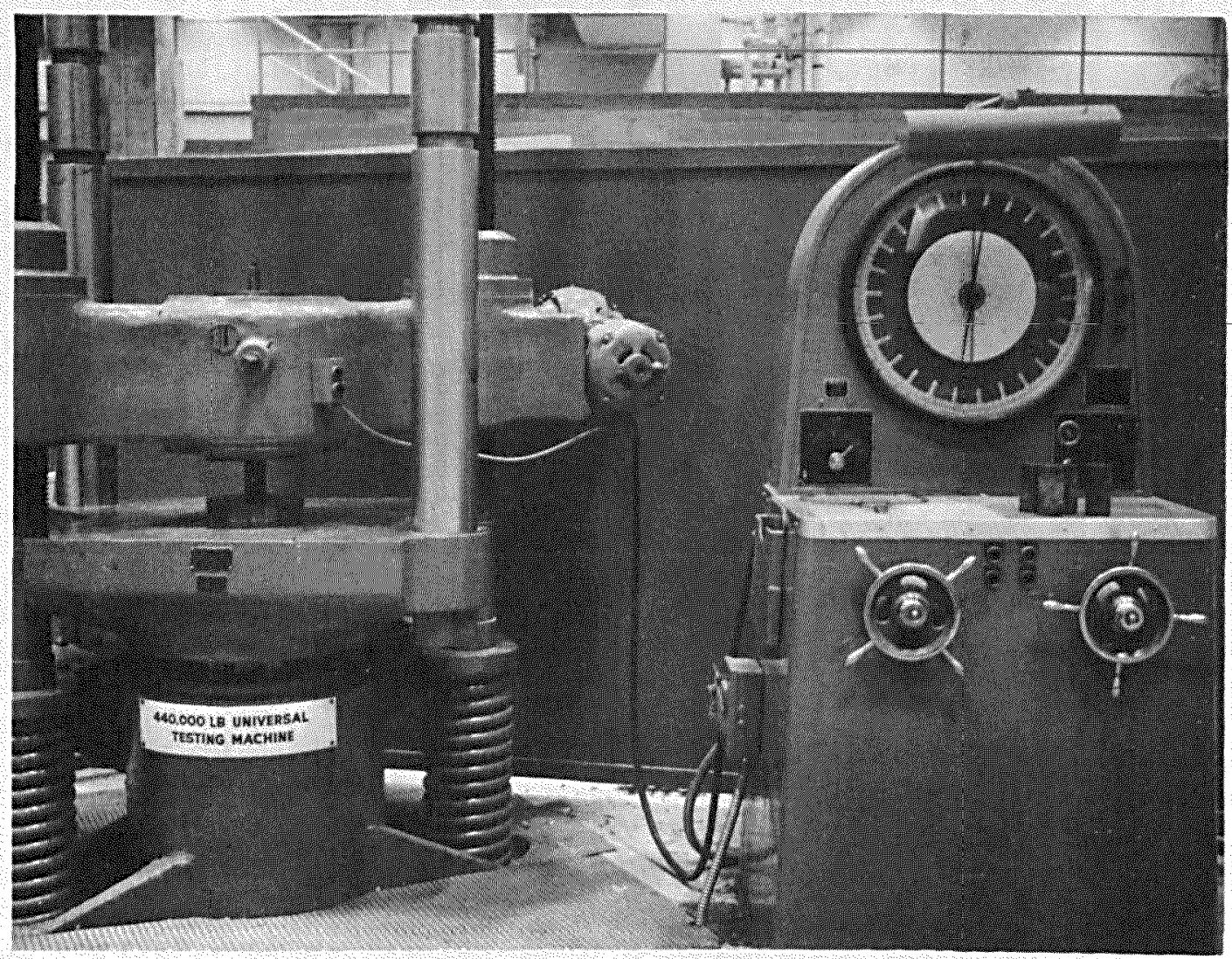

Figure 8. Baldwin 440,000-pound Universal Testing Machine 
CHAPTER 3

\section{PRESENTA'TION AND DISCUSSION OF RESULTS}

\section{General}

Phyoical properties of the various granite and tonalite apecimens tented wore determined according to the procedurea discused in Chapter 2 and are preaented in tabular form in Tables 1 and 2 .

The tetic ralues of Young' moduli are tangent moduli of elasticity and were computed at 50 percent of ultimate uniaxial compressive etrength. Static Young' moduli rere determined for a minimum of aix mecimen from each drill site represented (ten sites), thus excesding the optimum number of four specimens and minimum number of three recommended by the Bureau of Mines (1) for adequate evaluation of this particular property within a representative group of apecimens.

Ultraonic elastic constants rere computed from individual ralues of density, ultranonic compressional pulse velocity, and ultranonic whear pulae velocity which were determined for each apecimen by procedures as diacussed in Chapter 2. The equations used in the computation of ultrasonic elastic constanta are as follows:
(1) $E_{d y n}=\frac{o v_{p}^{2}\left(3 v_{p}^{2}-4 v_{a}^{2}\right)}{v_{p}^{2}-v_{a}^{2}}$
(2) $G_{d y z}=o v_{a}^{2}$ 


\section{TABLE 1}

Phyaical Property Test Renults

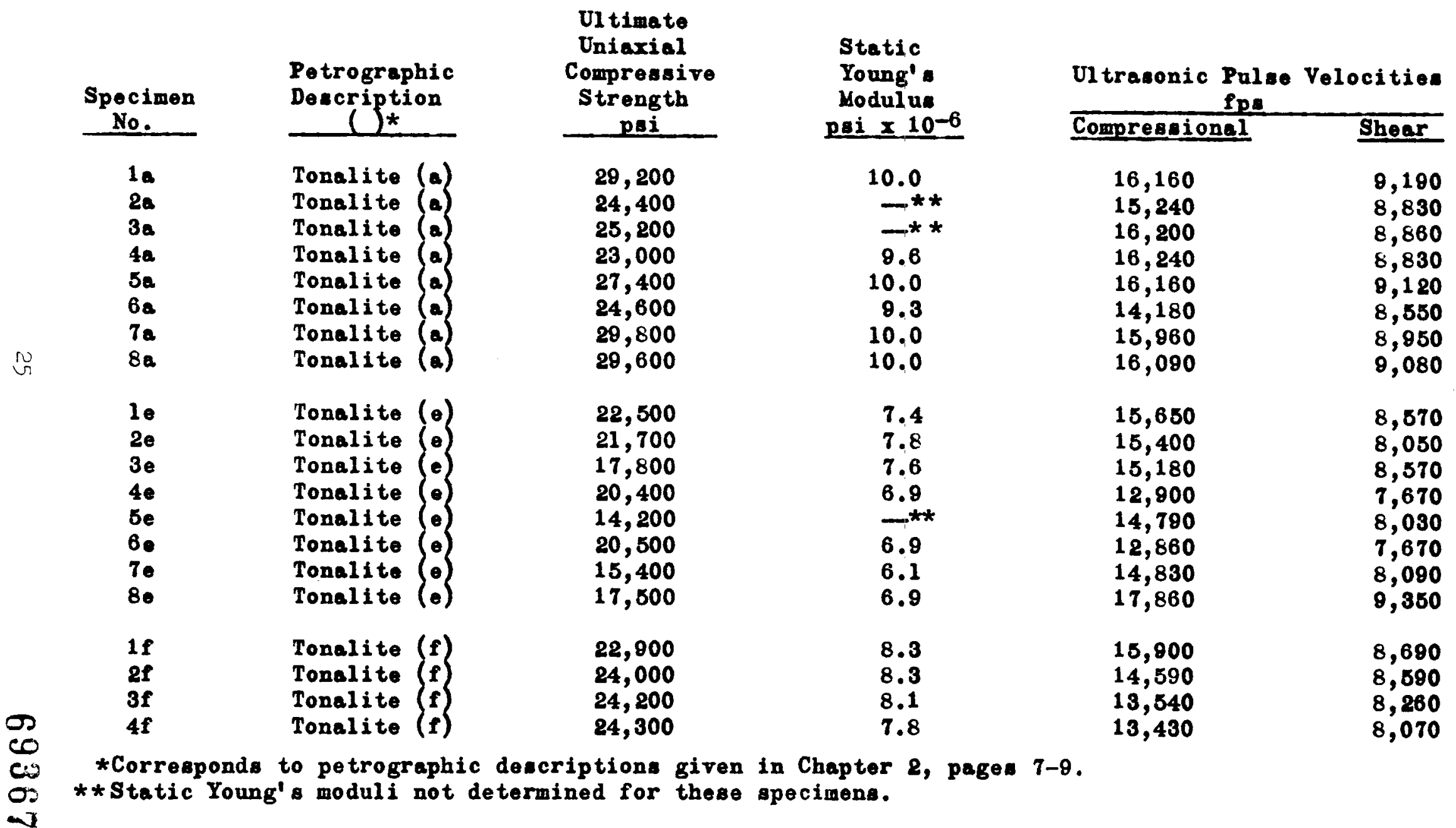


TABLE 1 (Cont'd)

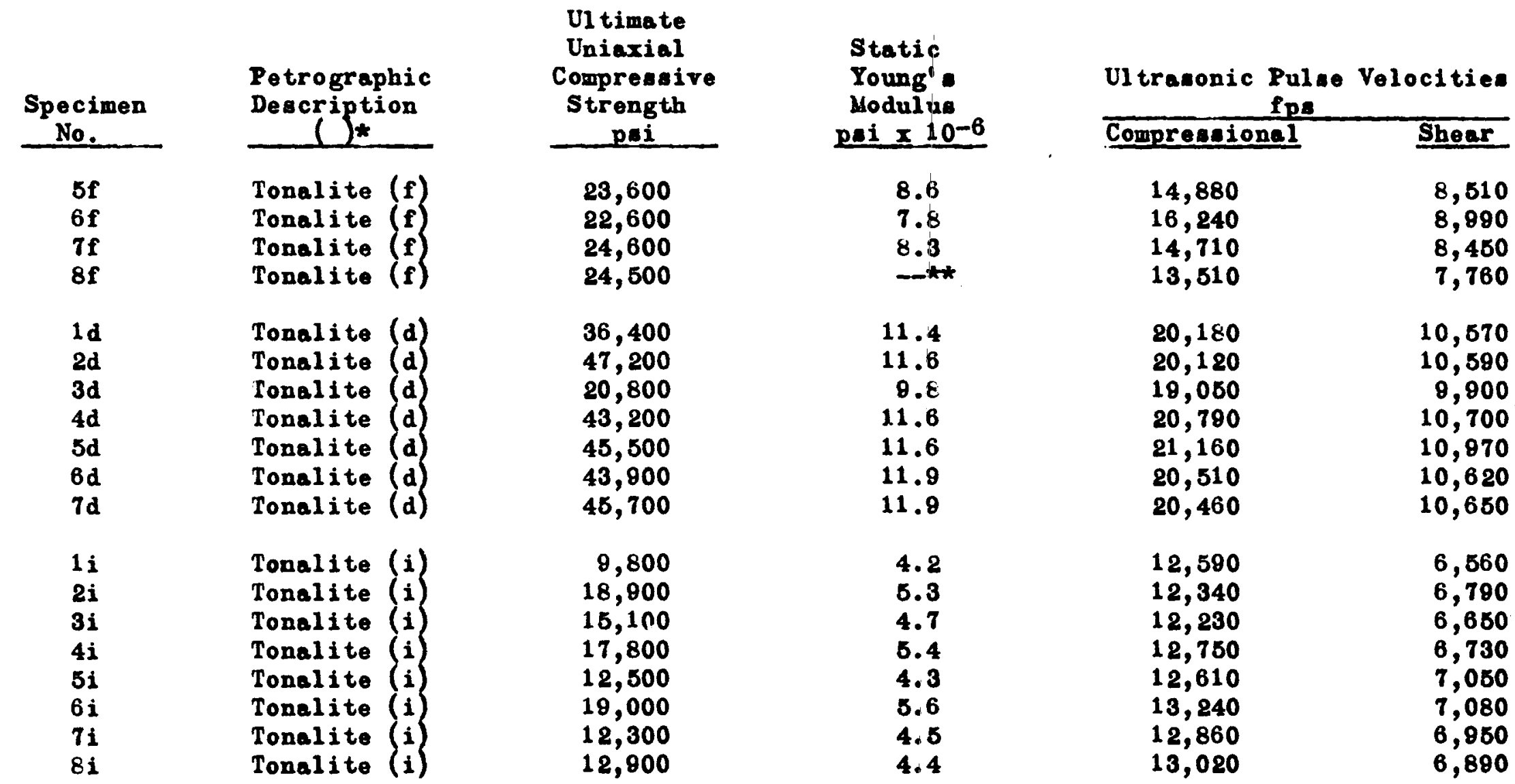

*Correaponds to petrographic descriptions given in Chapter 2, pagen 7-9. **Static Young' moduli not determined for these opecimens. 
TABLE 1 (Cont'd)

\begin{tabular}{|c|c|c|c|c|c|}
\hline \multirow{2}{*}{$\begin{array}{c}\text { Specimen } \\
\text { No. } \\
\end{array}$} & \multirow{2}{*}{$\begin{array}{l}\text { Petrographic } \\
\text { Dencription } \\
()_{*} \\
\end{array}$} & \multirow{2}{*}{$\begin{array}{c}\text { Ul timate } \\
\text { Uniaxial } \\
\text { Compreasive } \\
\text { Strength } \\
\text { pei } \\
\end{array}$} & \multirow{2}{*}{$\begin{array}{l}\text { Stetic } \\
\text { Young' } \\
\text { Modulua } \\
\text { pei } \times 10^{-6} \\
\end{array}$} & \multicolumn{2}{|c|}{$\begin{array}{c}\text { Ultramonic Pul } \\
\text { fpe Velocition } \\
\end{array}$} \\
\hline & & & & Compreneionel & Shear \\
\hline $\begin{array}{l}1 c \\
2 c \\
3 c \\
4 c \\
5 c \\
6 c \\
7 c \\
8 c\end{array}$ & $\begin{array}{l}\text { Granite } \\
\text { Granite }\end{array}$ c) & $\begin{array}{l}34,000 \\
31,100 \\
34,600 \\
32,800 \\
33,900 \\
32,300 \\
33,900 \\
25,600\end{array}$ & $\begin{array}{r}9.4 \\
8.6 \\
9.3 \\
9.4 \\
9.6 \\
9.8 \\
9.6 \\
10.0\end{array}$ & $\begin{array}{l}17,430 \\
16,360 \\
18,830 \\
18,130 \\
19,340 \\
18,100 \\
17,430 \\
18,120\end{array}$ & $\begin{array}{l}9,890 \\
8,750 \\
9,340 \\
9,560 \\
9,860 \\
9,530 \\
9,200 \\
9,400\end{array}$ \\
\hline $\begin{array}{l}1 \mathbf{g} \\
2 \mathbf{g} \\
3 \mathbf{g} \\
4 \mathbf{g} \\
5 \mathbf{g} \\
6 \mathbf{g} \\
\mathbf{7 g} \\
\mathbf{8} \mathbf{g}\end{array}$ & $\begin{array}{ll}\text { Granite } & (\mathrm{g} \\
\text { Granite } & (\mathrm{g} \\
\text { Granite } & (\mathrm{g} \\
\text { Granite } & \mathrm{g} \\
\text { Granite } & \mathrm{g} \\
\text { Granite } & \mathrm{g} \\
\text { Granite } & \mathrm{g} \\
\text { Granite } & (\mathrm{g})\end{array}$ & $\begin{array}{l}23,600 \\
21,100 \\
17,100 \\
25,800 \\
23,000 \\
19,000 \\
26,500 \\
20,800\end{array}$ & $\begin{array}{c}9.6 \\
9.6 \\
-\star \star \\
10.2 \\
10.0 \\
10.3 \\
9.6 \\
-\ldots \star\end{array}$ & $\begin{array}{l}17,900 \\
18,620 \\
18,040 \\
17,860 \\
18,350 \\
17,800 \\
18,870 \\
18,510\end{array}$ & $\begin{array}{l}9,530 \\
9,810 \\
9,690 \\
9,450 \\
9,630 \\
9,720 \\
9,580 \\
9,820\end{array}$ \\
\hline $\begin{array}{l}1 \mathrm{~h} \\
2 \mathrm{~h} \\
3 \mathrm{~h} \\
4 \mathrm{~h}\end{array}$ & 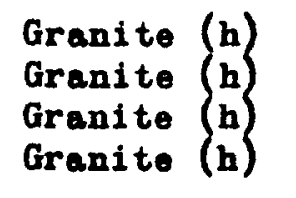 & $\begin{array}{l}18,400 \\
21,900 \\
23,100 \\
22,200\end{array}$ & $\begin{array}{l}-1 * \\
9.3 \\
9.4 \\
8.3\end{array}$ & $\begin{array}{l}17,870 \\
17,790 \\
18,070 \\
18,370\end{array}$ & $\begin{array}{l}9,220 \\
9,110 \\
9,640 \\
9,540\end{array}$ \\
\hline
\end{tabular}

*Correaponds to petrographic descriptions given in Chapter 2, pages 7-9. * Static Young's moduli not determined for these mpecimena. 


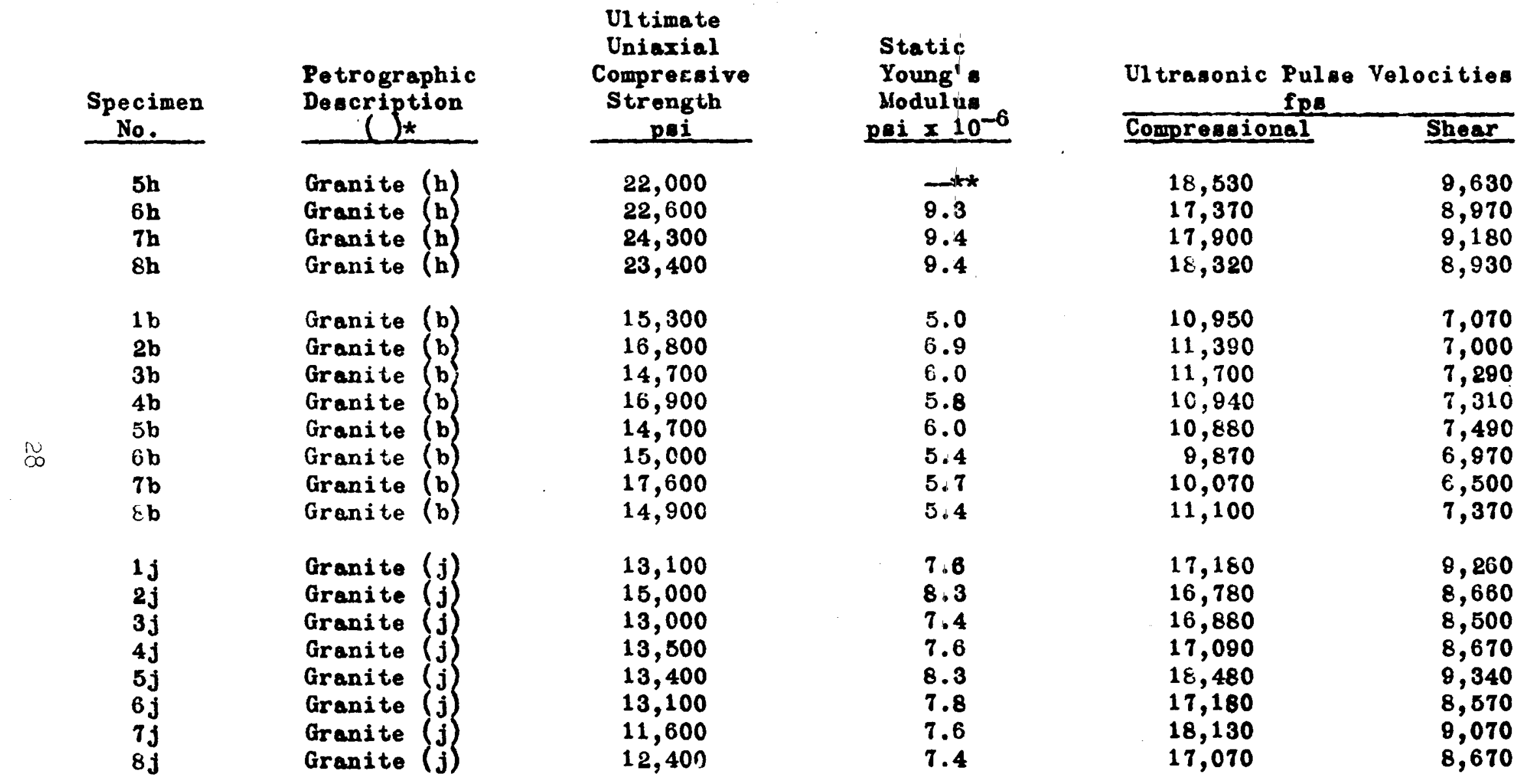

*Corresponds to petrographic descriptions given in Chapter 2, pages 7-9. * Static Young' woduli not determined for these specimens. 
TABLE 2

Computed UItrasonic Properties

\begin{tabular}{|c|c|c|c|c|}
\hline \multirow{2}{*}{$\begin{array}{l}\text { Specimen } \\
\text { No. }\end{array}$} & \multicolumn{3}{|c|}{ Ultrasonic Moduli, psi $\times 10^{-6}$} & \multirow{2}{*}{$\begin{array}{l}\text { Ultrasonic } \\
\text { Poisaon' } \\
\text { Ratto } \\
\end{array}$} \\
\hline & Young's & Bulk & Shear & \\
\hline $\begin{array}{l}1 a \\
2 a \\
3 a \\
4 a \\
5 a \\
6 a \\
7 a \\
8 a\end{array}$ & $\begin{array}{l}7.6 \\
6.8 \\
7.2 \\
7.2 \\
7.5 \\
6.3 \\
7.3 \\
7.4\end{array}$ & $\begin{array}{l}5.3 \\
4.6 \\
5.6 \\
5.7 \\
5.4 \\
3.7 \\
5.3 \\
5.3\end{array}$ & $\begin{array}{l}3.0 \\
2.8 \\
2.8 \\
2.8 \\
3.0 \\
2.6 \\
2.8 \\
2.8\end{array}$ & $\begin{array}{l}0.26 \\
0.25 \\
0.29 \\
0.28 \\
0.27 \\
0.21 \\
0.27 \\
0.27\end{array}$ \\
\hline $\begin{array}{l}1 e \\
2 e \\
3 e \\
4 e \\
5 e \\
6 e \\
7 e \\
8 e\end{array}$ & $\begin{array}{l}7.1 \\
6.4 \\
7.0 \\
5.4 \\
6.2 \\
5.4 \\
6.3 \\
8.6\end{array}$ & $\begin{array}{l}5.6 \\
5.6 \\
5.0 \\
3.3 \\
4.8 \\
3.2 \\
4.0 \\
7.6\end{array}$ & $\begin{array}{l}2.8 \\
2.4 \\
2.8 \\
2.2 \\
2.4 \\
2.2 \\
2.4 \\
3.3\end{array}$ & $\begin{array}{l}0.29 \\
0.31 \\
0.27 \\
0.23 \\
0.29 \\
0.22 \\
0.29 \\
0.31\end{array}$ \\
\hline $\begin{array}{l}1 f \\
2 f \\
3 f \\
4 f \\
5 f \\
6 f \\
7 f \\
8 f\end{array}$ & $\begin{array}{l}7.1 \\
6.8 \\
6.0 \\
5.8 \\
6.7 \\
7.6 \\
6.6 \\
5.5\end{array}$ & $\begin{array}{l}5.6 \\
4.2 \\
3.4 \\
3.4 \\
4.6 \\
5.8 \\
4.4 \\
3.7\end{array}$ & $\begin{array}{l}2.8 \\
2.7 \\
2.5 \\
2.4 \\
2.6 \\
3.0 \\
2.6 \\
2.2\end{array}$ & $\begin{array}{l}0.29 \\
0.23 \\
0.20 \\
0.22 \\
0.26 \\
0.28 \\
0.25 \\
0.25\end{array}$ \\
\hline
\end{tabular}


TABLE 2 (Cont'd)

\begin{tabular}{|c|c|c|c|c|}
\hline \multirow{2}{*}{$\begin{array}{c}\text { Specimen } \\
\text { No. } \\
\end{array}$} & \multicolumn{3}{|c|}{ Ul tramonic Moduli, pai $\times 10^{-6}$} & \multirow{2}{*}{$\begin{array}{l}\text { Altasonic } \\
\text { Poiason's } \\
\text { Ratio } \\
\end{array}$} \\
\hline & Young's & Bulk & Shear & \\
\hline $\begin{array}{l}1 d \\
2 d \\
3 d \\
4 d \\
5 d \\
6 d \\
7 d\end{array}$ & $\begin{array}{r}11.2 \\
11.2 \\
9.9 \\
11.7 \\
12.1 \\
11.4 \\
11.6\end{array}$ & $\begin{array}{r}9.9 \\
9.8 \\
9.0 \\
10.8 \\
11.0 \\
11.4 \\
10.4\end{array}$ & $\begin{array}{l}4.3 \\
4.3 \\
3.8 \\
4.5 \\
4.6 \\
4.4 \\
4.4\end{array}$ & $\begin{array}{l}0.31 \\
0.31 \\
0.32 \\
0.32 \\
0.32 \\
0.32 \\
0.31\end{array}$ \\
\hline $\begin{array}{l}1 \mathbf{i} \\
2 \mathbf{i} \\
3 \mathbf{i} \\
4 \mathbf{i} \\
5 \mathbf{i} \\
6 \mathbf{i} \\
7 \mathbf{i} \\
8 \mathbf{i}\end{array}$ & $\begin{array}{l}4.0 \\
4.2 \\
4.0 \\
4.2 \\
4.5 \\
4.6 \\
4.4 \\
4.4\end{array}$ & $\begin{array}{l}3.6 \\
3.2 \\
3.2 \\
3.6 \\
3.3 \\
3.9 \\
3.6 \\
3.8\end{array}$ & $\begin{array}{l}1.5 \\
1.6 \\
1.6 \\
1.6 \\
1.8 \\
1.8 \\
1.7 \\
1.7\end{array}$ & $\begin{array}{l}0.31 \\
0.28 \\
0.29 \\
0.31 \\
0.27 \\
0.30 \\
0.29 \\
0.31\end{array}$ \\
\hline $\begin{array}{l}1 c \\
2 c \\
3 c \\
4 c \\
5 c \\
6 c \\
7 c \\
8 c\end{array}$ & $\begin{array}{l}8.0 \\
7.1 \\
9.5 \\
8.5 \\
9.2 \\
8.4 \\
7.8 \\
8.2\end{array}$ & $\begin{array}{l}6.7 \\
5.9 \\
8.0 \\
7.3 \\
8.7 \\
7.3 \\
6.8 \\
7.4\end{array}$ & $\begin{array}{l}3.1 \\
2.7 \\
3.4 \\
3.2 \\
3.5 \\
3.2 \\
3.0 \\
3.1\end{array}$ & $\begin{array}{l}0.30 \\
0.30 \\
0.31 \\
0.31 \\
0.32 \\
0.31 \\
0.31 \\
0.32\end{array}$ \\
\hline $\begin{array}{l}1 \mathrm{~g} \\
\mathbf{2 g} \\
\mathbf{3} \mathbf{g} \\
\mathbf{4} \mathbf{g}\end{array}$ & $\begin{array}{l}8.3 \\
7.8 \\
8.6 \\
8.2\end{array}$ & $\begin{array}{l}7.0 \\
8.2 \\
7.0 \\
7.0\end{array}$ & $\begin{array}{l}3.2 \\
3.0 \\
3.3 \\
3.1\end{array}$ & $\begin{array}{l}0.30 \\
0.34 \\
0.30 \\
0.31\end{array}$ \\
\hline
\end{tabular}


TABLE 2 (Cont'd)

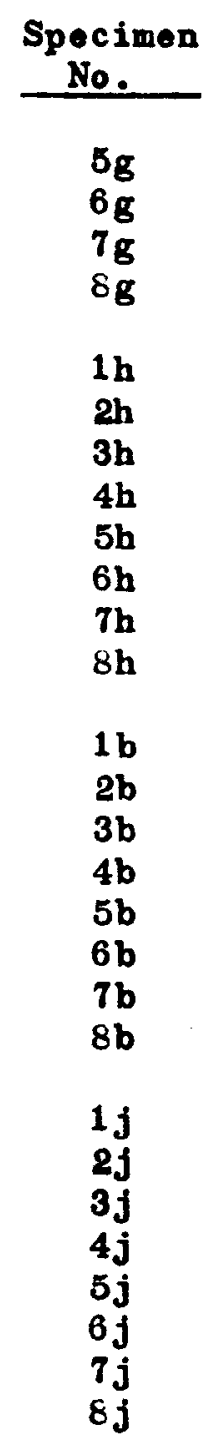

\begin{tabular}{|c|c|c|}
\hline \multicolumn{3}{|c|}{ Ul tranonic Moduli, pal $\times 10^{-6}$} \\
\hline Young'a & Bulk & Shear \\
\hline $\begin{array}{l}8.5 \\
8.6 \\
8.4 \\
8.8\end{array}$ & $\begin{array}{l}7.5 \\
6.7 \\
7.4 \\
7.5\end{array}$ & $\begin{array}{l}3.3 \\
3.3 \\
3.2 \\
3.4\end{array}$ \\
\hline 8.2 & 7.6 & 3.1 \\
\hline 8.0 & 7.6 & 3.0 \\
\hline 8.0 & 8.8 & 3.4 \\
\hline 8.7 & 7.8 & 3.3 \\
\hline 8.9 & 8.0 & 3.4 \\
\hline 7.7 & 7.1 & 2.9 \\
\hline 8.1 & 7.6 & 3.1 \\
\hline 7.8 & 8.4 & 2.9 \\
\hline 4.1 & 1.8 & 1.8 \\
\hline 4.2 & 2.3 & 1.8 \\
\hline 4.5 & 2.4 & 1.8 \\
\hline 4.2 & 1.7 & 1.9 \\
\hline 4.2 & 1.6 & 2.0 \\
\hline 3.5 & 1.2 & 1.7 \\
\hline 3.5 & 1.6 & 1.5 \\
\hline 4.3 & 1.8 & 1.8 \\
\hline 8.1 & 6.6 & 3.1 \\
\hline 7.1 & 6.6 & 2.7 \\
\hline 6.9 & 6.8 & 2.6 \\
\hline 7.1 & 6.9 & 2.7 \\
\hline 8.4 & 8.2 & 3.2 \\
\hline 7.1 & 7.2 & 2.7 \\
\hline 8.0 & 8.0 & 3.0 \\
\hline 7.3 & 7.0 & 2.7 \\
\hline
\end{tabular}

Ul tranonic

Poimon'

Ratio

0.31

0.29

0.31

0.30

0.32

0.32

0.33

0.32

0.32

0.32

0.32

0.34

0.14

0.20

0.18

0.10

0.05

0.01

0.14

0.11

0.30

0.32

0.38

0.33

0.33

0.33

0.33

0.33 

(3) $\mathrm{K}_{\mathrm{dyz}}=\frac{0\left(3 \mathrm{v}_{\mathrm{p}}^{2}-4 \mathrm{~V}_{\mathrm{a}}^{2}\right)}{3}$
(4) $v_{\text {dyn }}=\frac{v_{p}^{2}-2 v_{p}^{2}}{2\left(v_{p}^{2}-v_{p}^{2}\right)}$

where

$$
\begin{aligned}
& E_{\text {dyn }}=\text { ultrasonic Young' o modulue of eleoticity in pai }
\end{aligned}
$$

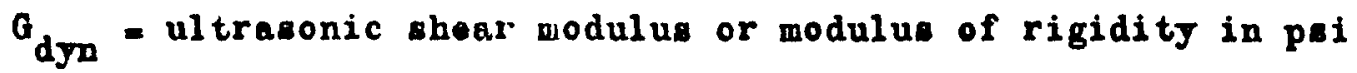

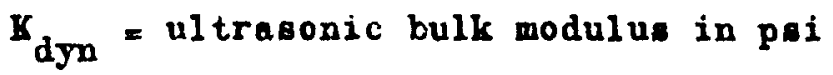

$$
\begin{aligned}
& \nu_{\text {dyn }}=\text { ultranonic Poisaon's ratio } \\
& 0 \text { = denoity in pound-aecond }{ }^{2} \text { per inch }{ }^{4} \\
& v_{p}=\text { ultrasonic compresaional pulse velocity in inchen per } \\
& \text { second } \\
& V_{\text {a }}=\text { ultranonic hear pulse velocity in inches per second. }
\end{aligned}
$$

The number of pecimens for which these constant rere determined in all cases exceeded both the minimum and optimum number of tents per group ( 3 and 6 , respectively) recommended by the Bureau of Mines (1). Typical modes of failure exhibitod by the eventy-nine rock core apecimens teoted in uniaxial compression are illustrated in the photograph in Figure 9. Explosive type failures yielding the fragments illuetrated in Figure $9(a)$ were typical of failures in the tronger tonalites, i.e., those yielding ultimeto uniaxial compresnive trengthe greater than 35,000 pai. The conical type fallure surfaces illustrated in Figure $9(b)$ were typical of the neture of failure exhibited by the remainder of the specimens tented.

In order to evaluate the linear degree of ansociation botreen the various pairs of physical properties of interest in this investigation, correlation coefficients rere computed for each of the 


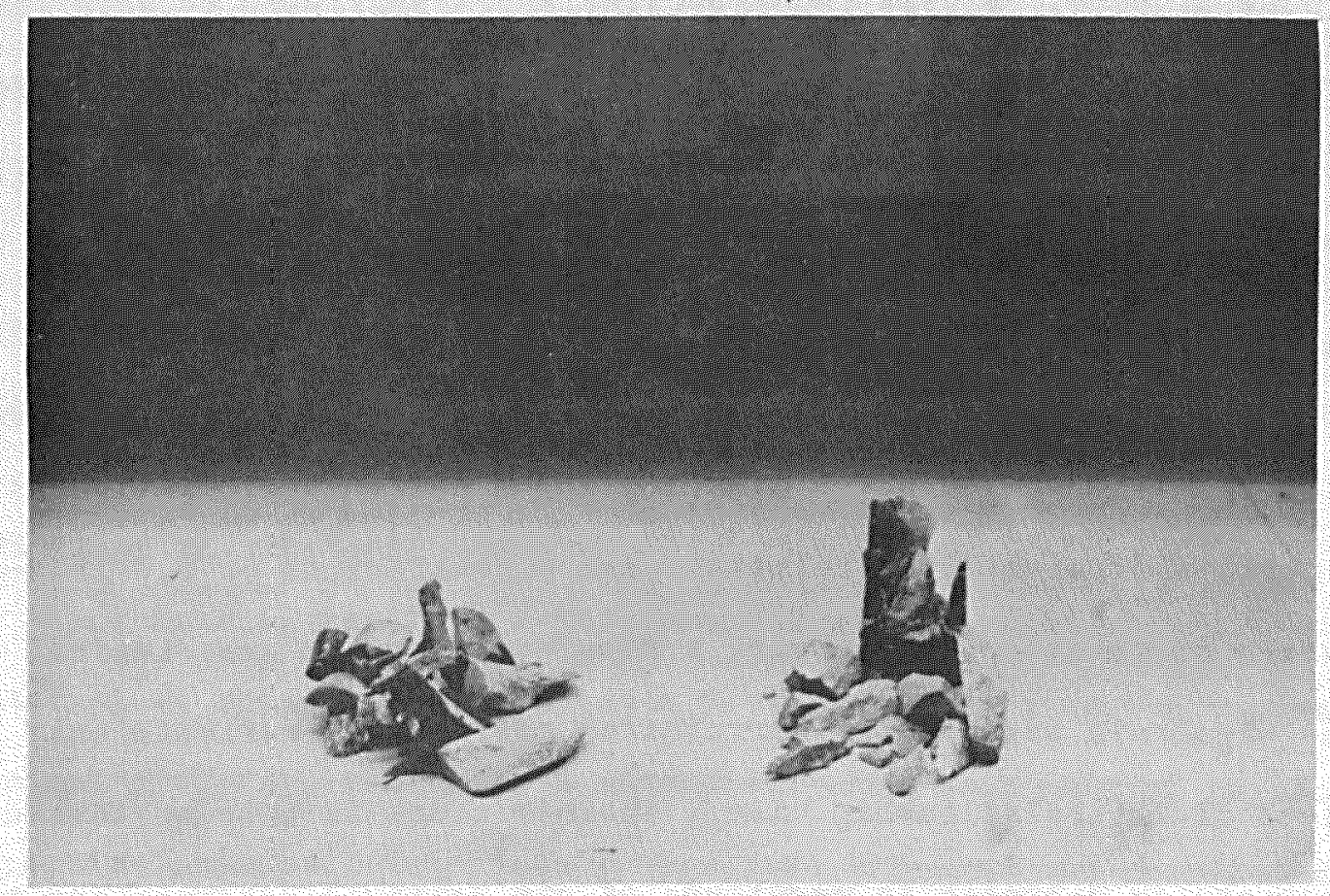

a. Troical Lrolosive Troe Failure Surfacea

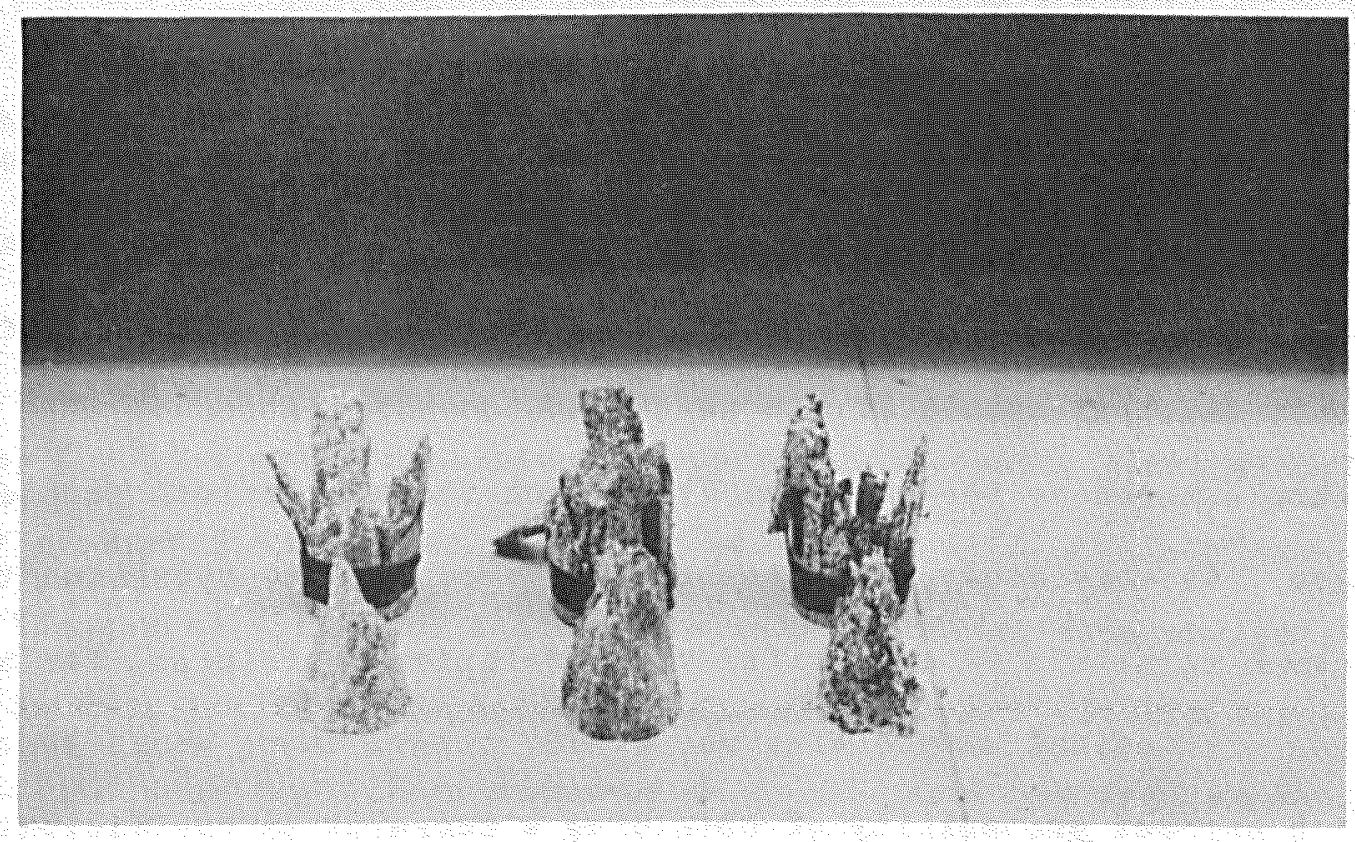

b. Typical Conical Type Fallure Surfaces

Figure 9. Typical Failures of Rock Cores in Uniaxial Compression 
groupe of data. A least-oquaren line was also fitted to each data group, the intention being to give a visual representation of the degree of linear correlation betreen the particular phyaical properties of interest.

The correlation coefficient $(r)$ is a meanre of the degree of interdependence betreen the particular variables under etudy, with a coefficient of 1.0 or -1.0 indicating a perfect association, i.e., a perfect straight 1 ine relation, and a coefficient of 0.0 indicating no rolation watsoever, a completely random association. The algebraic aign of the correlation coefficient reflects only the slope of the relationobip, i.e., whether there is a trend torard increase or decrease in magnitude of one variable accompanying an increase in the magnitude of other variables.

Once the correlation coefficients for the various groups of data rere determined, it remained to evaluate the aignificance of these correlations, i.e., determine the probability of getting a correlation coefficient as large as the one actually obtained from the statistical ample if, in actuality, no correlation of this nature existed in the universe from which the etatistical mample was taken. In thi sudy, the probability level used to determine the minimum magnitude of a significant correlation coefficient for a given statistical mample aize was 0.995 . Thus, there rould be only a 0.3 percent probability of obtaining a correlation coefficient of a magnitude greater than or equal to the predetermined value from a atatiotical ample taken from universe in which no correlation of this nature actually exinted. A table of critical values for 
correlation coefficiente correnponding to thi chosen probability level and the various atatiotical comple sizes uned in this atudy in prenented as Appendix II.

The actual mathematical determination of the individual correlation coeficionts and equations for least-aquares lines ras, for each deta group, performed on a General Electric 400 computer.

\section{Diacuanion of Correlationa}

The remaining portion of this chapter will consist of the presentation of mcatter diagram (data plots) reprenenting the various phyaical property correlations attempted. For each pair of phyaical properties examined, four date group rere arranged and correlated. These groups rere comprined an followas

Group 1: All tonalite apecimens teated from the Sierra Nevada Batholith, California.

Group 2: All tonalite specimen tested.

Group 38 All granite apecimen tested.

Group 4: All spocimens tested.

Thus, for each pair of physical properties diacunaed, there will be four acatter diagrams, one for each group.

The correlations and scatter diagram reaulting from analyaia of the data jielded by opecimen compriaing Group 1 (Sierra Narada Batholith tonalites) were compared to those reaulting from analyis of the data yielded by the apecimen compriaing Group 2 (all tonalitea). The objective of thin comparicon ras to ovaluate the degreo of acatter which might be attributed to variation in grain aize alone 
within the particular rock type. Variation in percentage mineral composition and geologic history rere kept to practical minimum for the Group 1 data (all apecimens come from throe holes within very close proximity of each other) and, for the Group 2 data, were allowed to vary within the confines imposed by restriction to the one particular rock type (tonalite). Therefore, close mimilarity between the correlation coefficients and acetter diagrams jielded for the two groups of data would suggest, for the particular pair of variables under conalderation, that variation in grain aize was of primary importance in the determination of degree of acatter typical of the association between those tro phyaical propertien for that rock type. On the other hand, aignificant disaimilarity in nature of the physical property correlation and correlation coefficienta (i.e., a larger amount of scatter and lemser degree of linear ansociation for the Group 2 data than for the Group 1 data) rould indicate, for the particular pair of physical propertiea being examined, that variation in grain size, as opposed to variation in percentage mineral composition and geologic history as confined to the limits imposed by the particular rock type, was of leaser aigaificance in the determination of the degree of acatter characteristic of the particular rock property correlation in question.

The correlations and acatter diagrame resulting from analyais of the date yielded by acimens comprising Groups 2 and 3 rere compared to those resulting from analyois of the data yielded by apecimens comprising Group 4 (all specimens in Groups 2 and 3 combined), the objective being to evaluate the effects of minimal variation in rock type on the nature of physical property correlations 
obtained for tatiatical data amplen involving more than one igneoun rock type. Lo data Groups 2 and 3 reprosented indiridual rock typen (tonalite and granite, renpectively) while data Group 4 represented both rock types, significant differences in the quality and orientation of the correlations determined for the three data groups bould indicate the effecto of alight variation in rock type on the nature of the resulting physical property correlations. Moreover, since the granites and tonalites involved in this investigation rere relatively homogeneous and isotropic intrusire igneous rocks, and ance the percentage mineral compositions of the tro rock types are not extremely removed from one anotber (11), the rock property correlatione determined for the data compriaing Group 4 should indicate a reasonable maximum degree of linear asociation and minimum degree of acatter to be expected for the particular paira of phyoical properties examined and for a statiatical data sanple which includes specimen representing more than one rock type. Co Veraus Ultramonic Pulse Velocitien $\left(v_{p}\right.$ and $\left.v_{g}\right)$. Scatter diagrams developed to illustrate the relationships botreen uniarial comprosaive trength and ultrasonic compressional pulse velocity are presented in Figuren 10 through 13. Figures 14 through 17 graphically illustrate the relationships found to exiat between ultimate uniarial compreasive trength and ultrasonic shear pulse relocity as determined in this invertigation.

The degrees of correlation characteristic of these two pairs of phyaical properties $\left(C_{0}\right.$ veraus $v_{p}$ and $C_{0}$ reraus $v_{s}$ ) rere noticeably higher for the data jielded by the tonalite apecimens alone than for the data jielded by the granite apecimens alone. In particular, the 


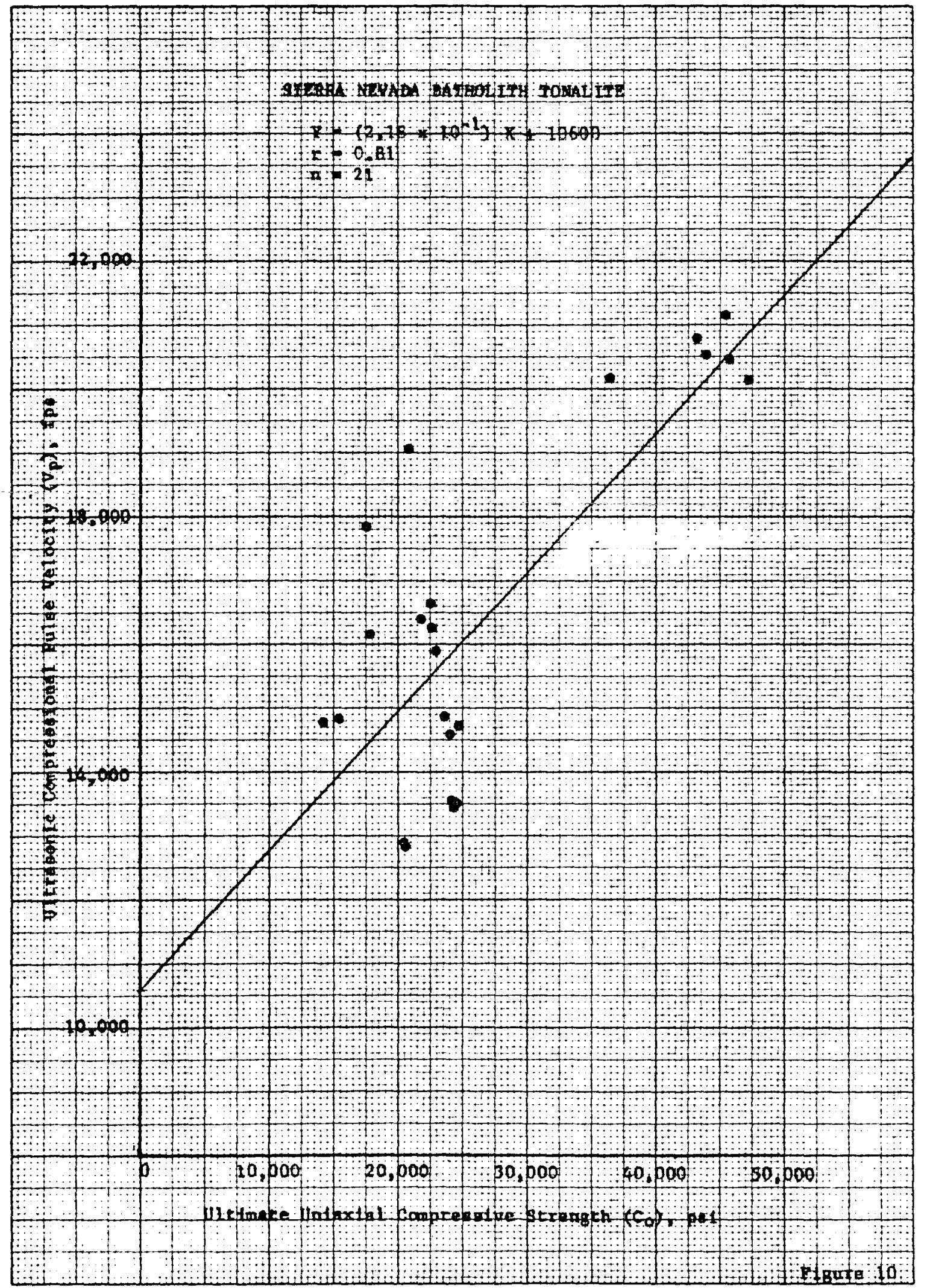




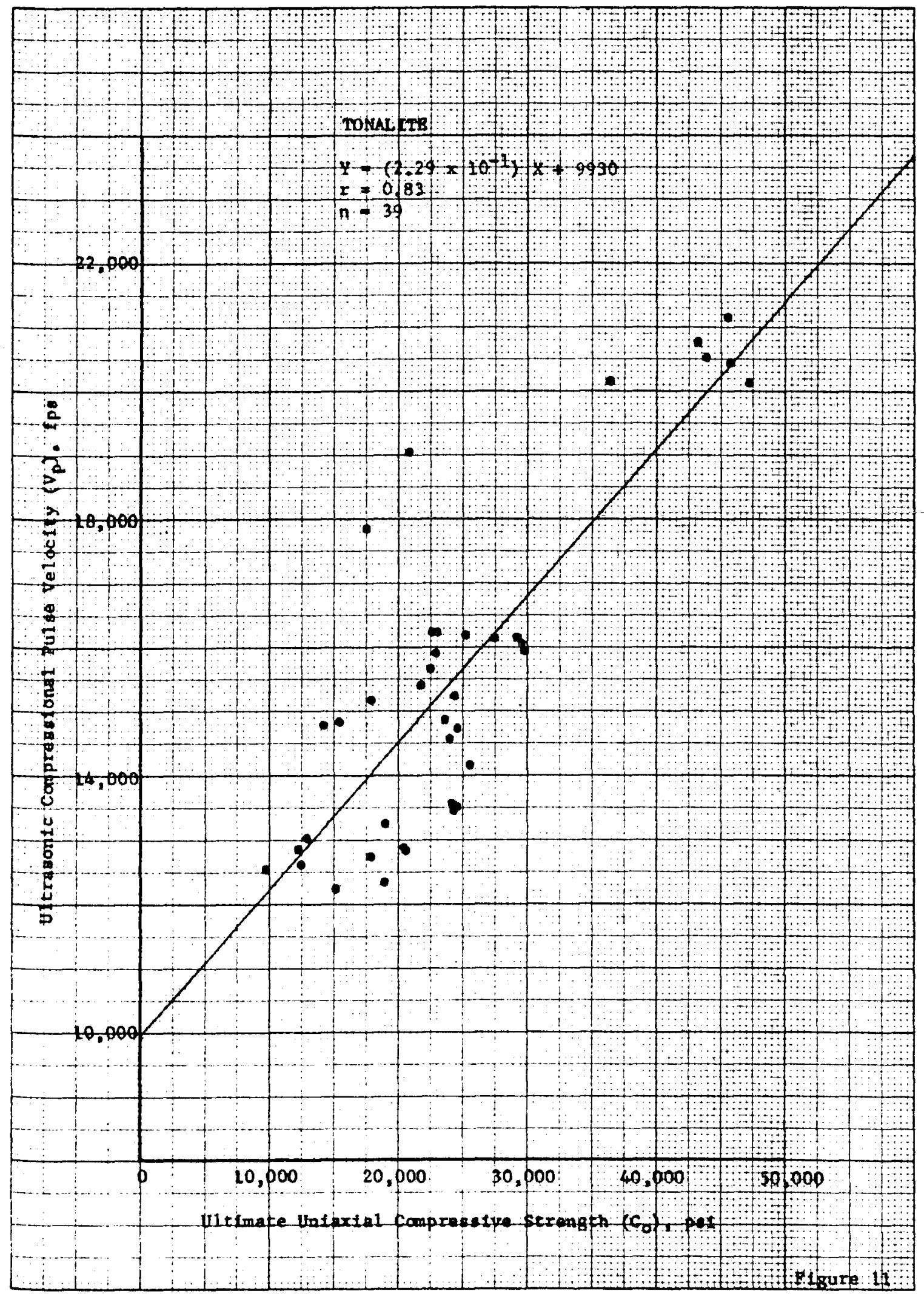




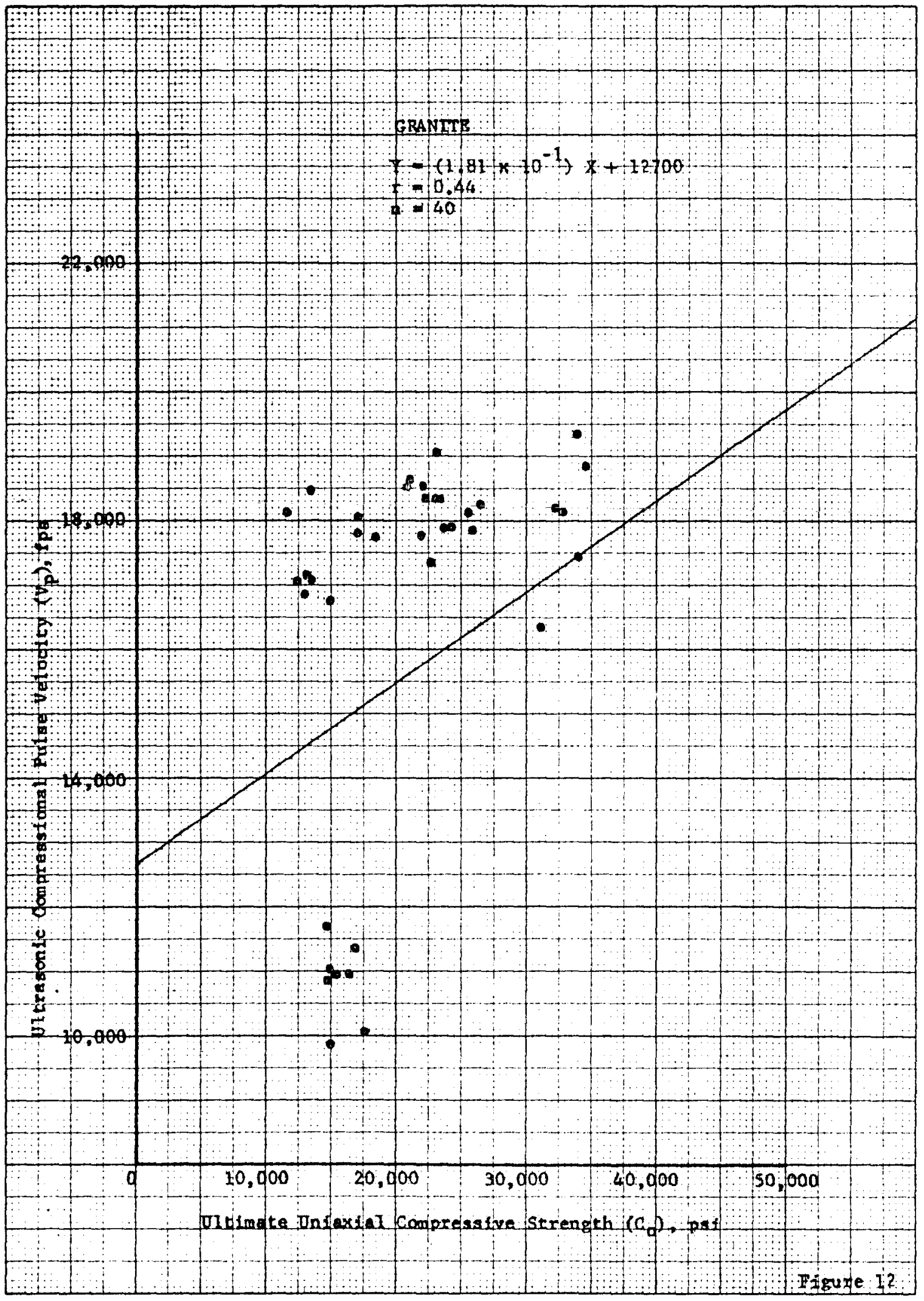




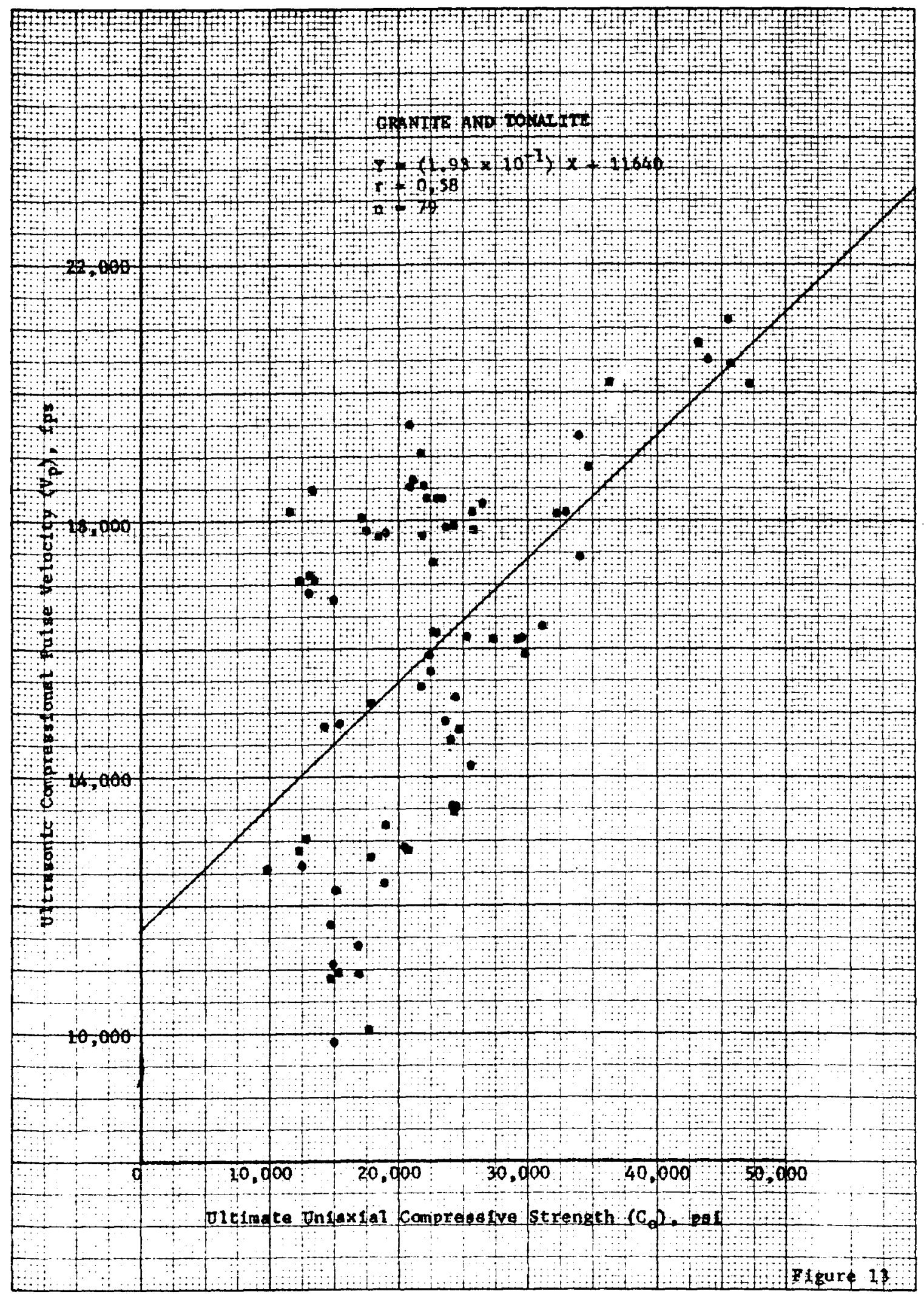




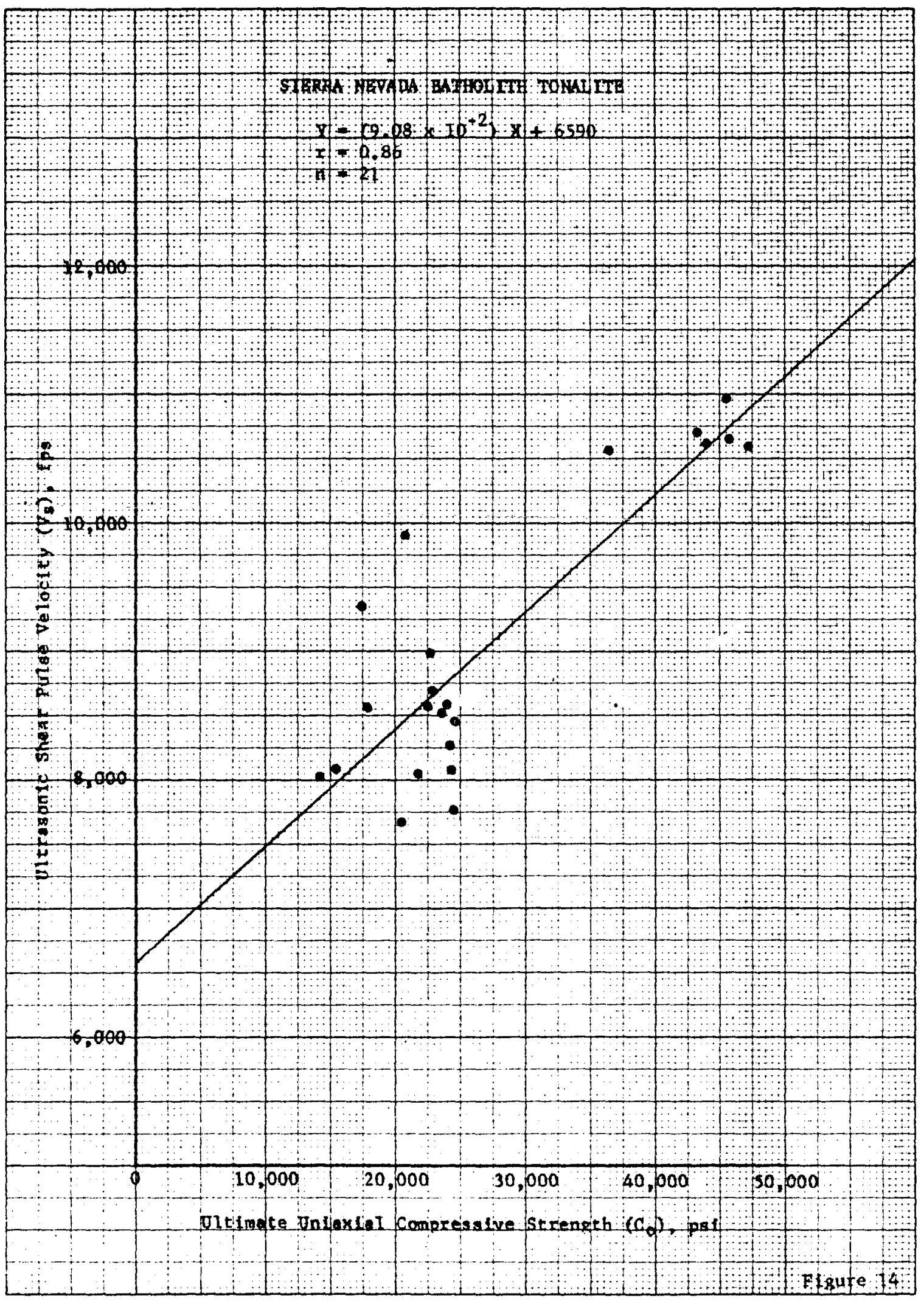




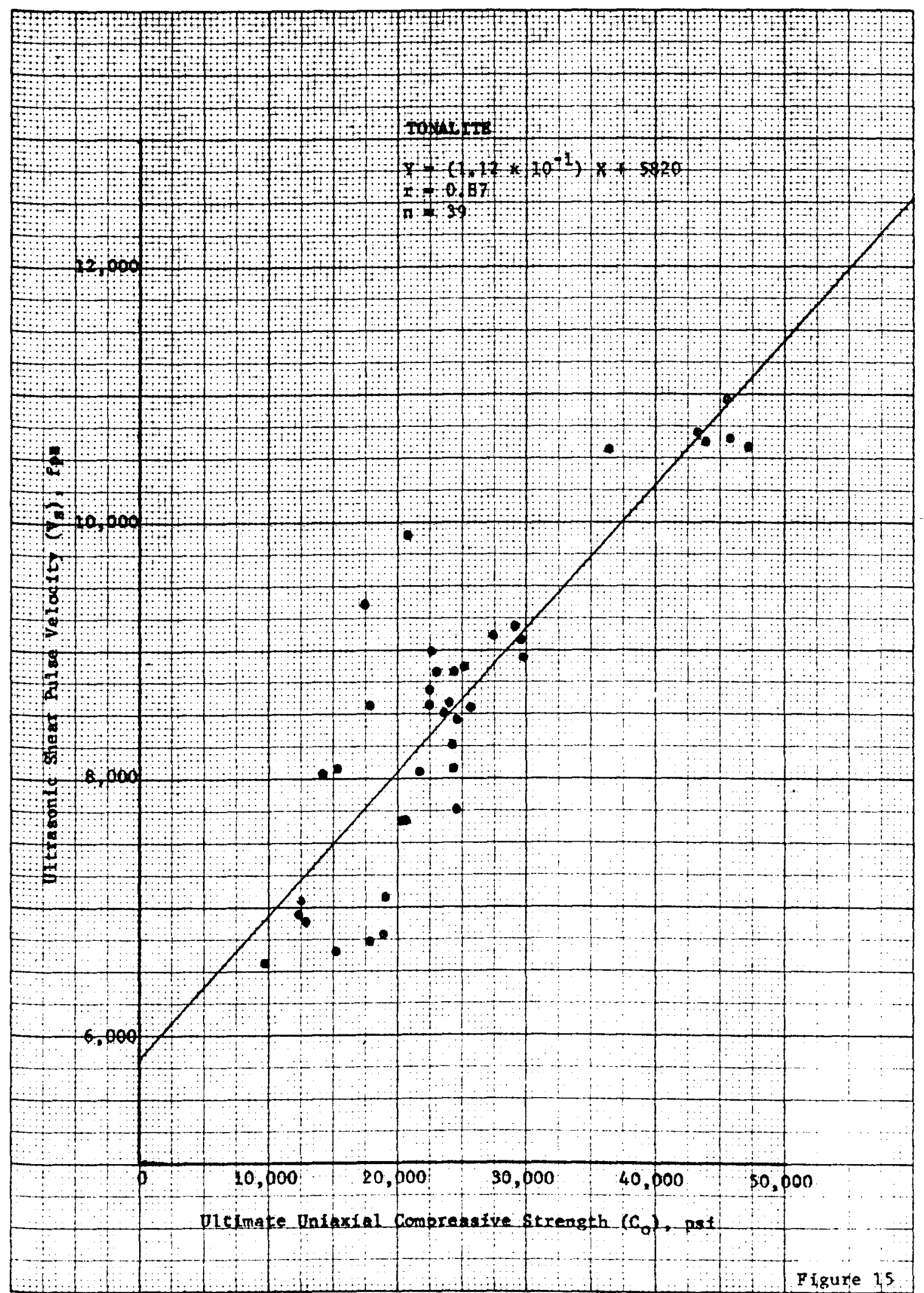




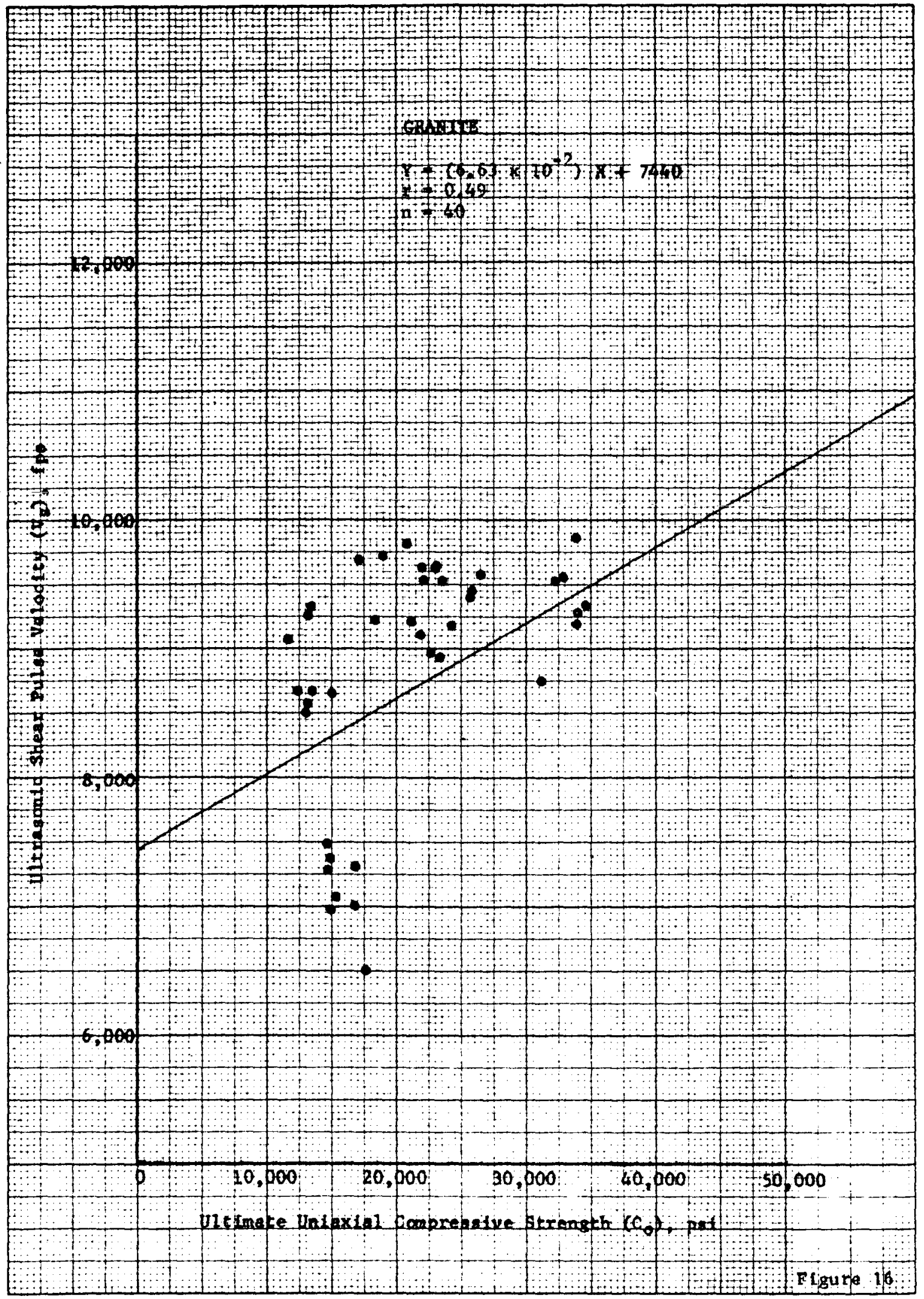




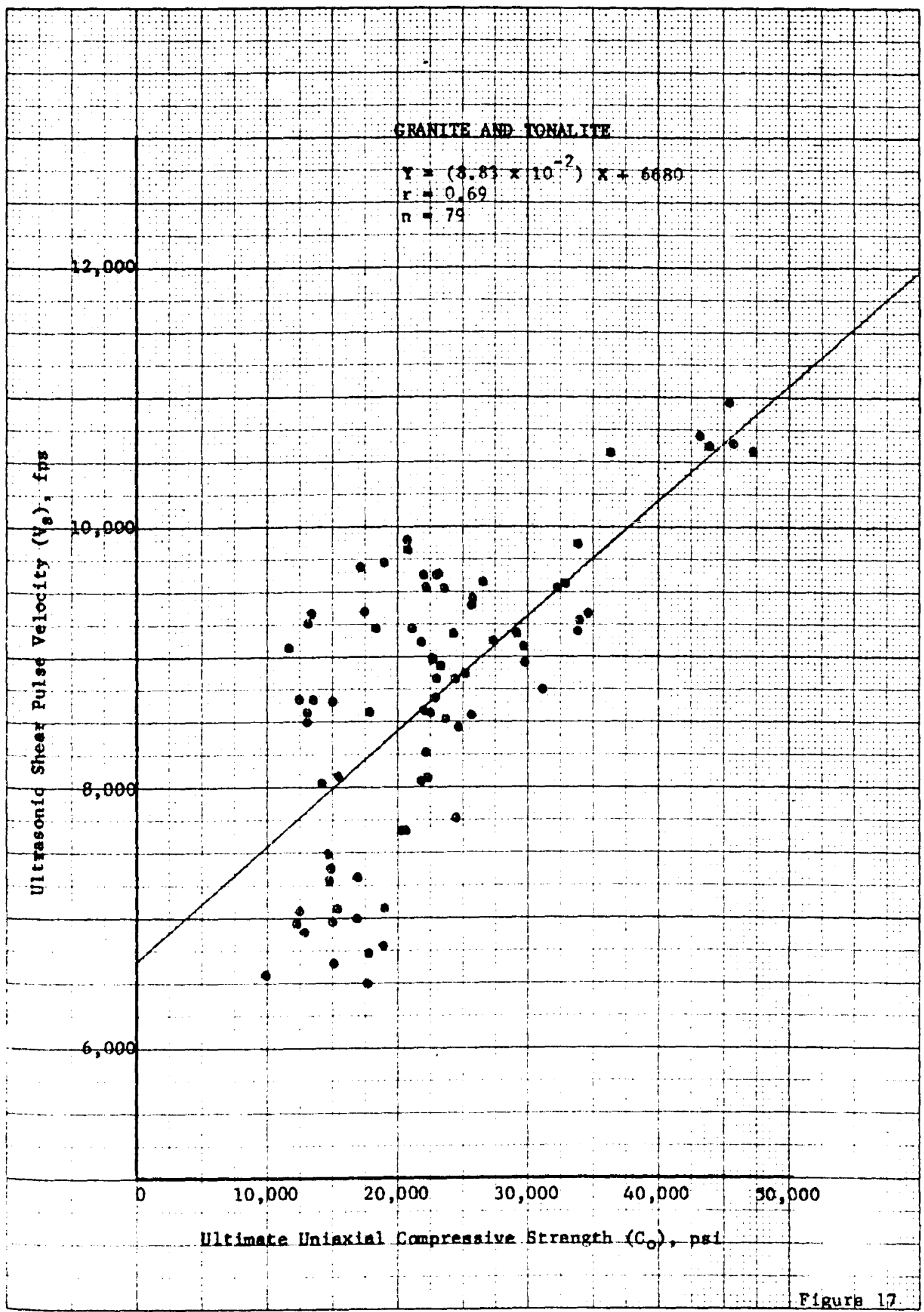


correlation coefficienta (Teble 3) (r) determined for the Group 2 tonalites were considerably larger than the correaponding critical ralue (given in Appendix II), while the correlation coefficients determined for the granitea alone rere only 0.44 and 0.49 for $C_{0}$ rersua $V_{p}$ and $C_{0}$ versus $V_{g}$, respectively, lor enough to be of questionable significance.

When the data jielded by the tonalites and granites rere combined (for the particular paira of physical propertiea) and examined as a single data sample, the result, in both instances, was a rather noticeable increase in scatter over and beyond the acatter typical of either the granite or tonalite data alone. Also, while the resulting correlation coefficiente (for the Group 4 data) rere slightly higher than thowe yielded for the granite data alone, they rere substantially lower than the values determined for the tonalite date sone. Thus the net effect, in these instances, appears to have been e considerable acrifice of quality of the better ocetter plote and phyaicel property correlations (Group 2 tonaliten) rosulting from the introduction of data exhibiting trends of a nomewhat different character and lesser quality (Group 3 granites).

4 comperison of the correlation coefficient. (Table 3) determined for the Groups 1 and 2 tonalites and examination of the acatter plote produced from date jielded by these tro groups of apecimens revealed no ignificant differences in magnitude of the correlation coefficients or quality of the scatter diagrams for either $c_{0}$ veraus $V_{p}$ or $C_{0}$ veraue $V_{w}$. Thus, for these particular correlatione, variation in grain eize, rather than abatantial variation in percentage 


\section{Correlation Coefficient Obtained For Varioun Paira of Phyaical Propertien}

Correlation Coefficient Obtained For,

Sierra

\section{Phyaical}

Propertien

Correleted

$\mathrm{C}_{\mathrm{o}} \operatorname{ra} \mathrm{V}_{\mathrm{p}}$

$c_{0} \nabla * V$

$C_{0} v: E_{\mathrm{d} J n}$

$c_{0} \nabla G_{\mathrm{djn}}$

$C_{0} \mathbf{r s} \mathrm{K}_{\mathrm{d} y \mathbf{n}}$

$C_{0}$ ve $v_{\text {djp }}$

$E_{\tan }$ va $v_{p}$

$E_{\tan }$ V* $V_{\text {s }}$

$E_{\tan }$ va $E_{\mathrm{d} y n}$

$E_{\tan } r G_{\mathrm{d} y n}$

$E_{\text {tan }} r a K_{\text {dyn }}$

$E_{\tan } v v_{\mathrm{d}} \mathrm{ym}$
Nevada

A11

Batholith

Tonalitea

(Goup 1)

0.81

0.86

0.86

0.87

0.81

0.49

0.88

0.92

0.98

0.93

0.88

0.58
Tonalitea

Teated

(Group 2)

0.83

0.87

0.87

0.88

0.89

0.20

0.86

0.92

0.90

0.91

0.79

0.11
A11

Graniten

Tested

(Group 3)

0.44

0.48

0.49

0.50

0.38

0.33

$0.8 \theta$

0.81

0.90

0.80

0.85

0.80

\section{A11}

Granite.

and

Tonaliten

Tented

(Oroup 4)

0.58

0.69

0.71

0.73

0.58

0.24

0.86

0.82

0.80

0.81

0.80

0.45 
mineral composition and geologic history as allowed rithin the confines of the apecific rock type, appeared to be the primary factor contributing to the degree of scatter in the tonalite data plots.

$C_{0}$ Versus Ultranonic Moduli ( $E_{d y n}, G_{d y n}$, and $K_{d j n}$ ). Scatter diagram illustrating the general relationships exiating between ultimate uniaxial comprearive atrength $\left(C_{0}\right)$ and ultrasonic Young's modulus $\left(\mathrm{E}_{\mathrm{djn}}\right)$, ultrasonic hear modulua $\left(\mathrm{G}_{\mathrm{dyn}}\right)$, and ultrasonic bulk modulus ( $\mathbf{K}_{\text {dyn }}$ ) are given in Figures 18 through 29. Correlations and data plots for comparable groups for each of the above three paire of variablea vere generally aimilar, probably a reflection upon the aimilar origin of the various values of the three different ultrasonic moduli (all were computed from values of ultrasonic shear and comprenional pulae relocitie and apecific gravitien determined for the individual specimens).

Of particular interest was the fact that no appreciable changes in magnitudes of coefficients of linear correlation (an opposed to the magnitudea of those value determined for $C_{0}$ veraus $V_{p}$ and $C_{0}$ versus $v_{a}$ ) were effected by the use of ultrasonic elastic moduli in correlations with ultimate atrength instead of the easier to determine pulse velocitied (previounly discuesed). While correlations of ultimate uniaxial compreasive atrength $\left(C_{0}\right)$ with ultranonic ahear modulus $\left(G_{d y n}\right)$ yielded the highest correlation coefficients of any of the correlations in which ultimate strength ras involved as a variable $(0.87,0.88,0.50$, and 0.73 for Groups $1,2,3$, and 4 , respectivelJ), thene coefficients rere not oufficiently greater than those yielded by correlations of ultimate atrength with ultrasonic 


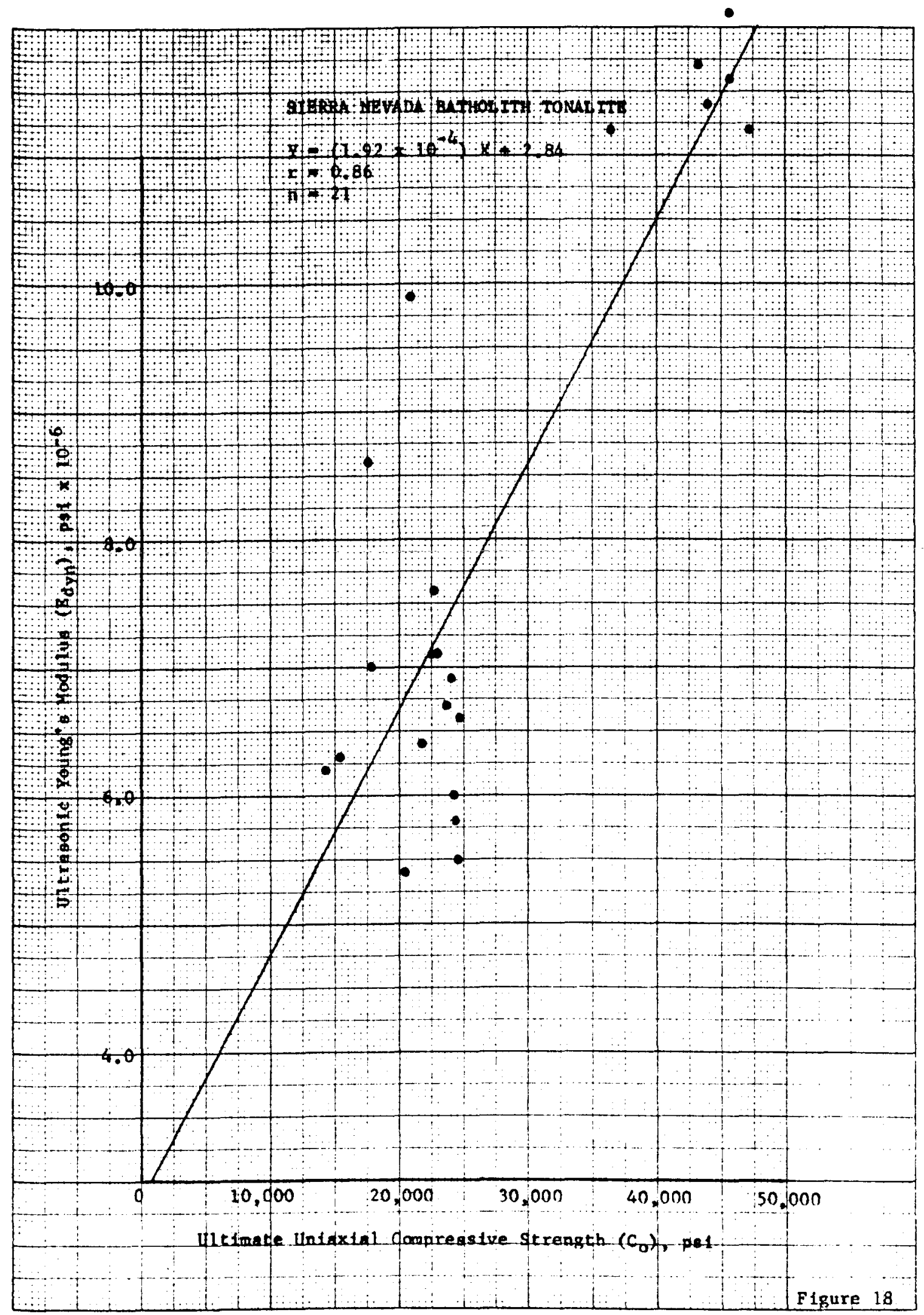




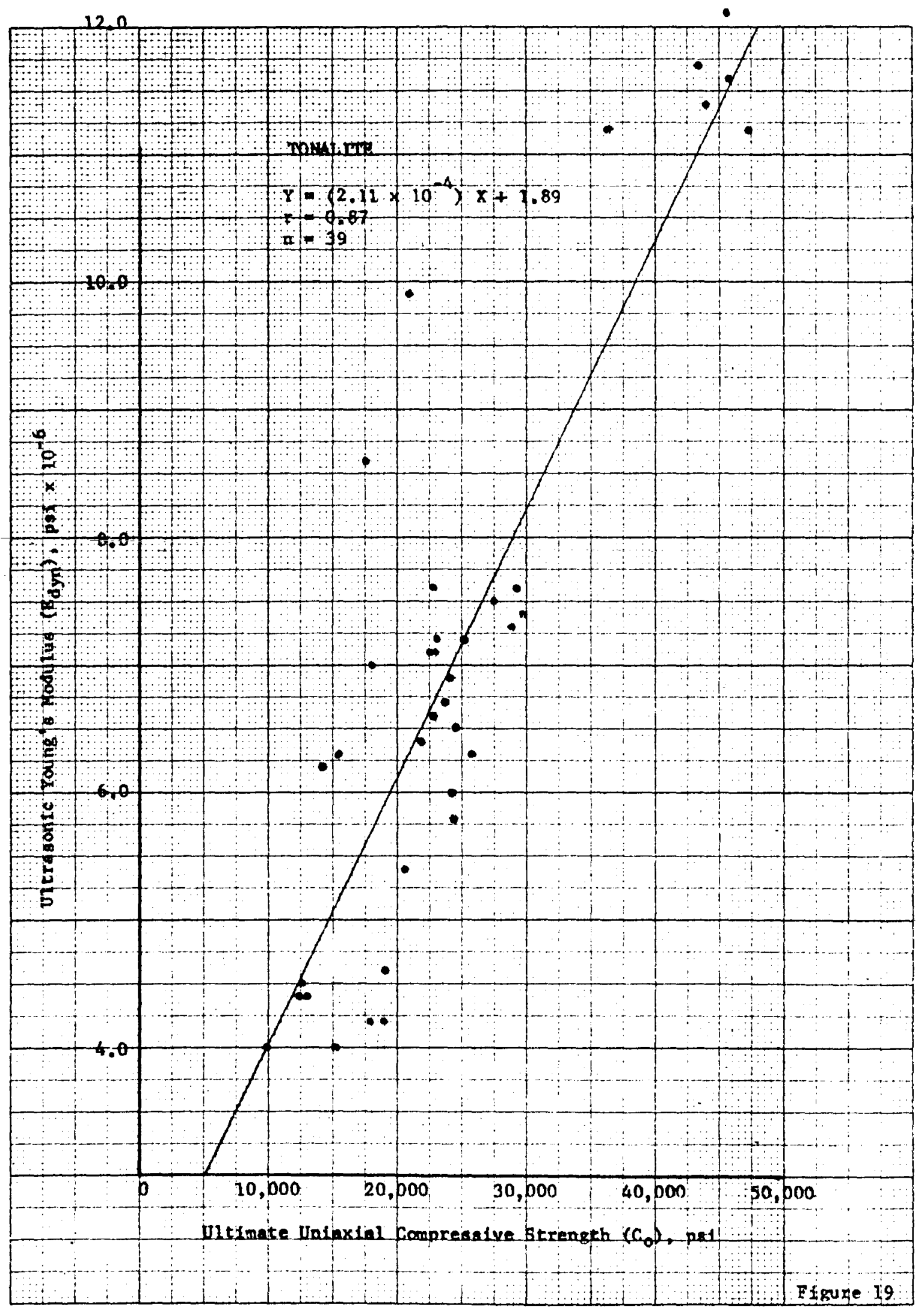




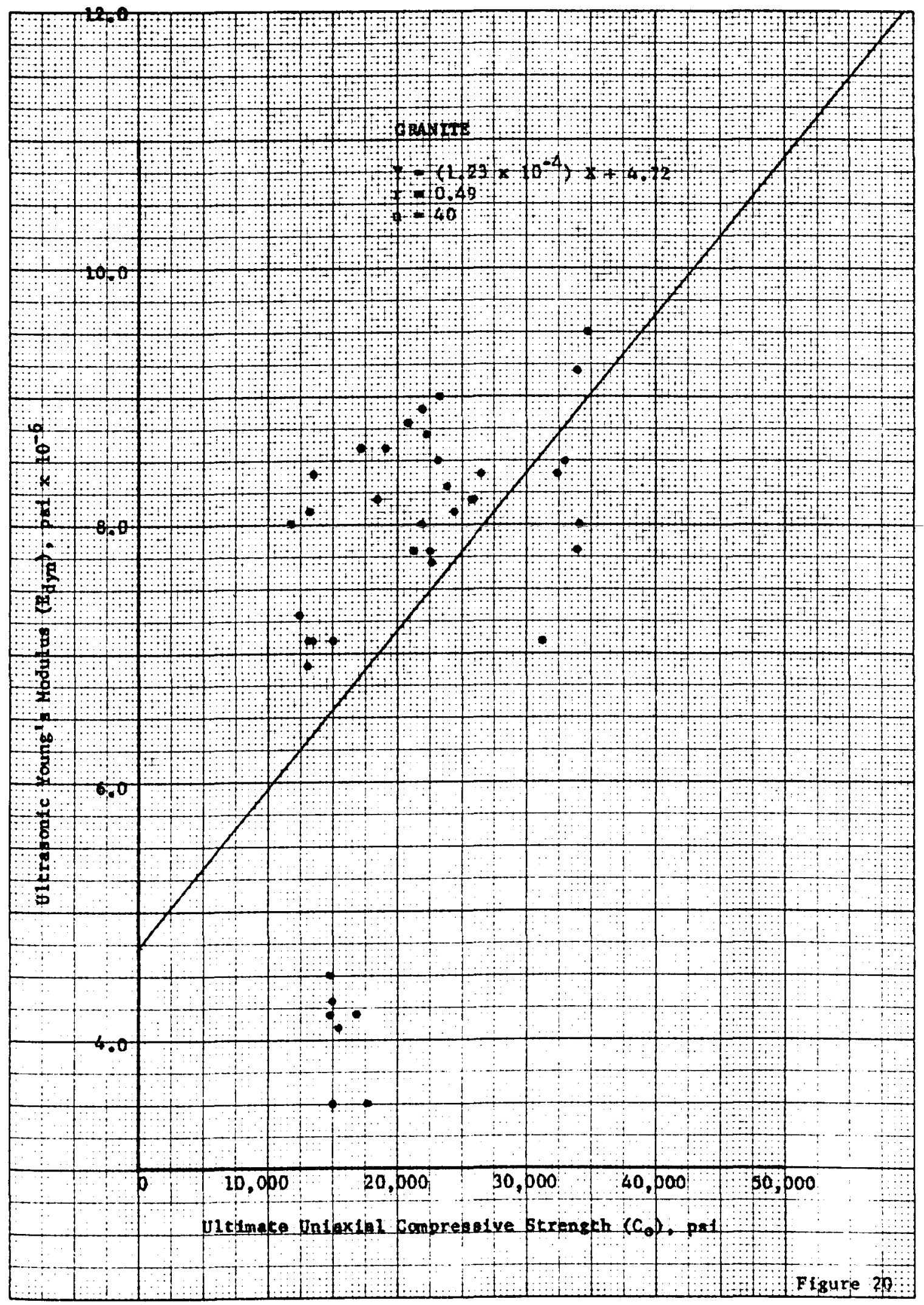




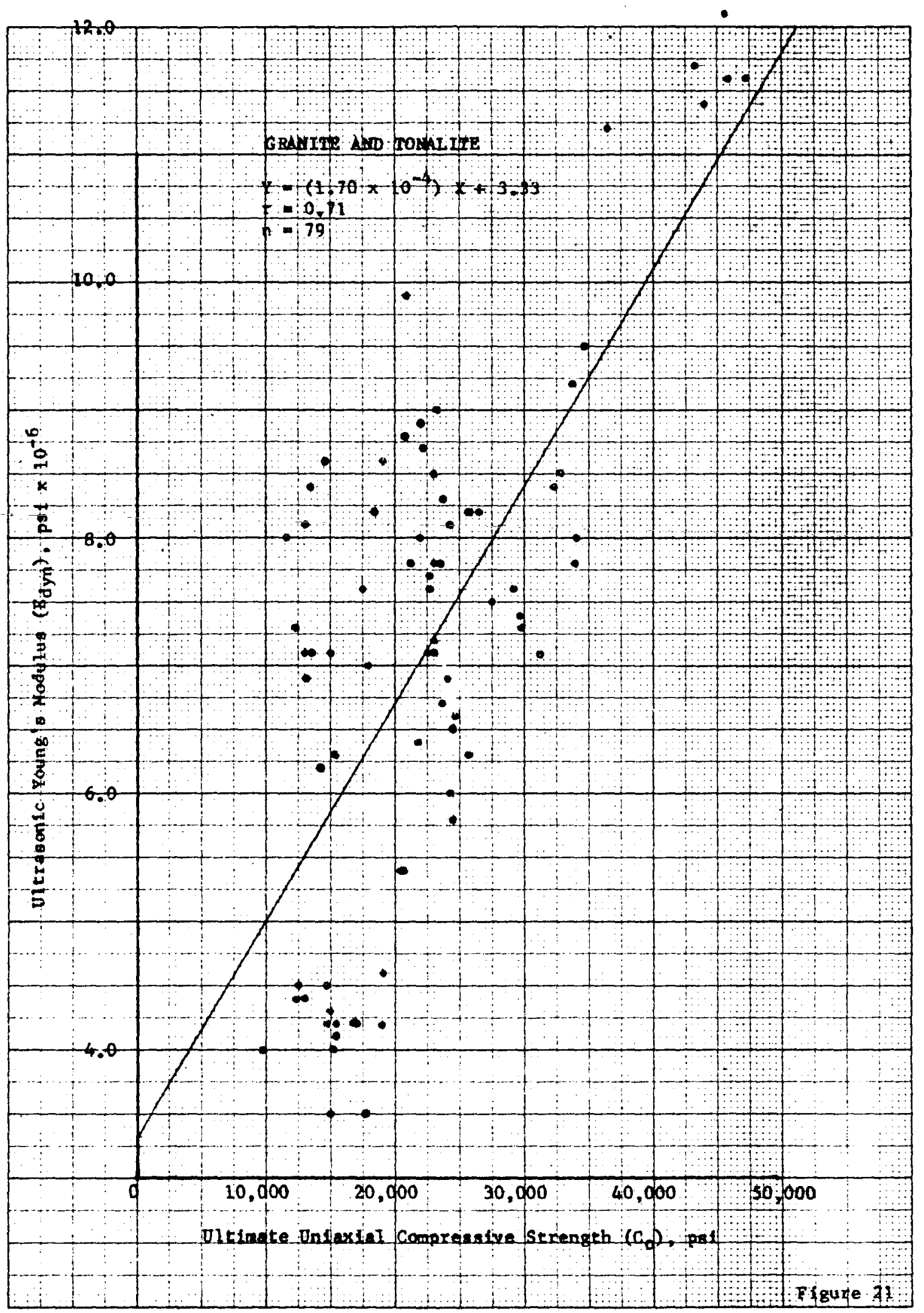




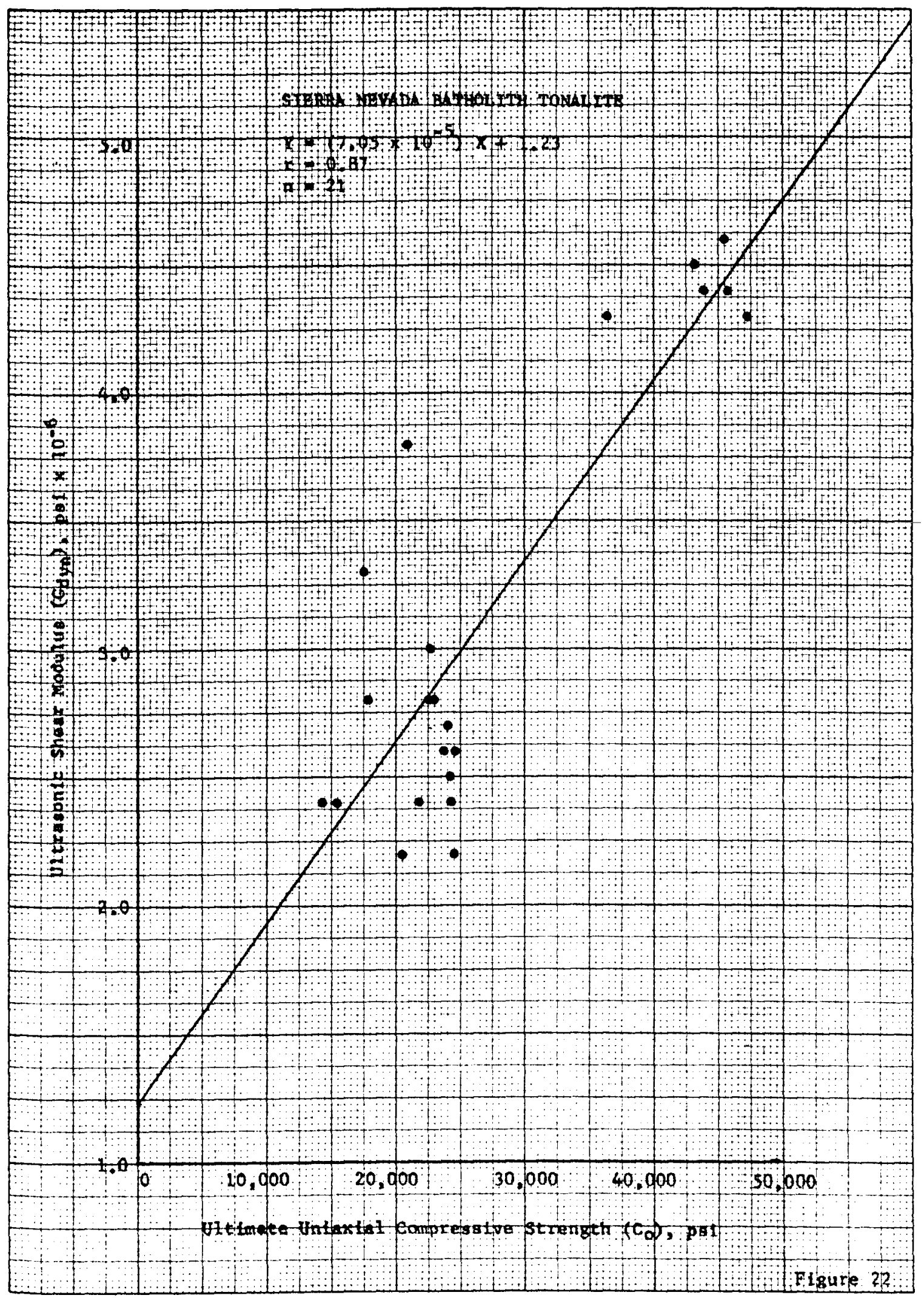




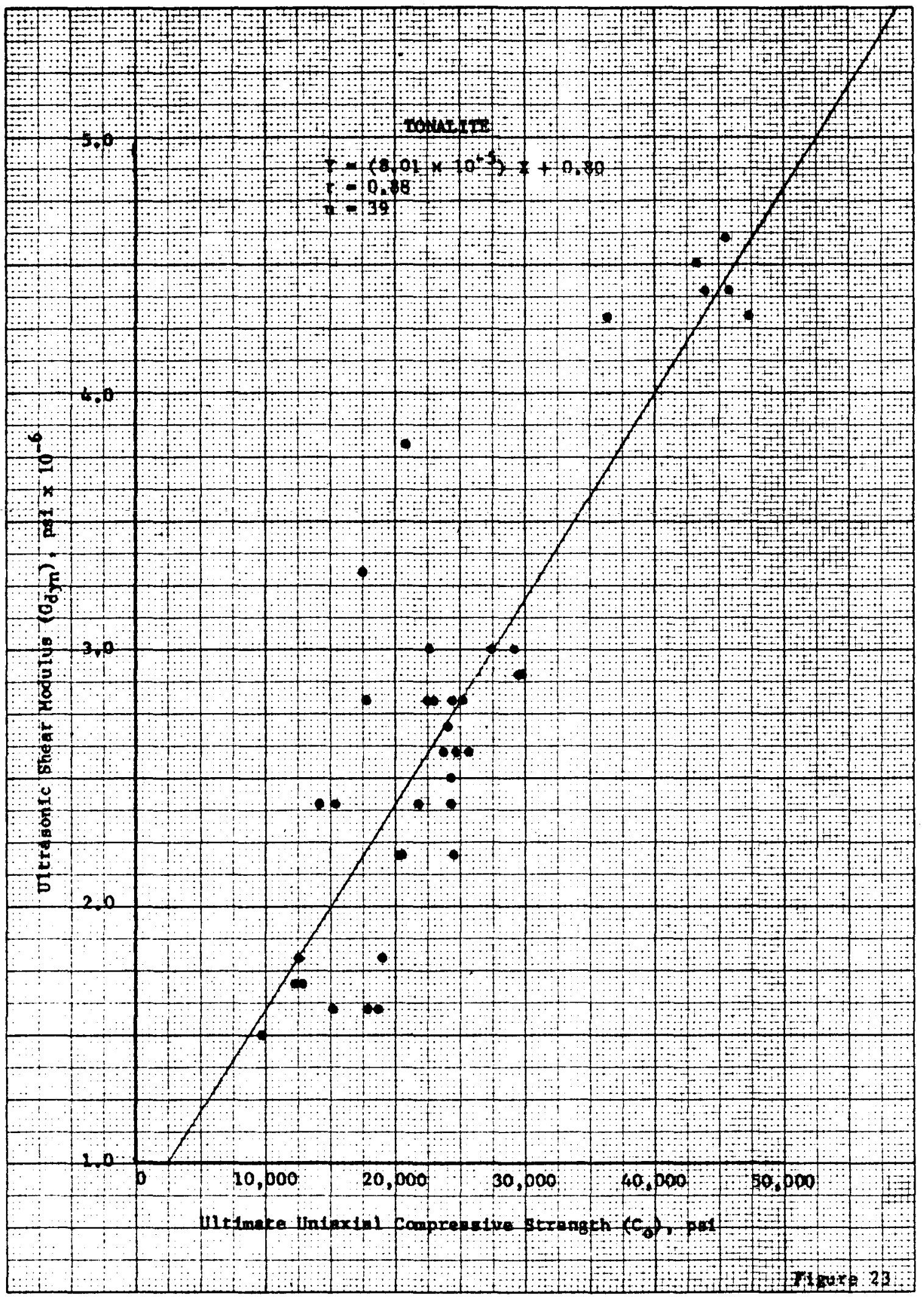




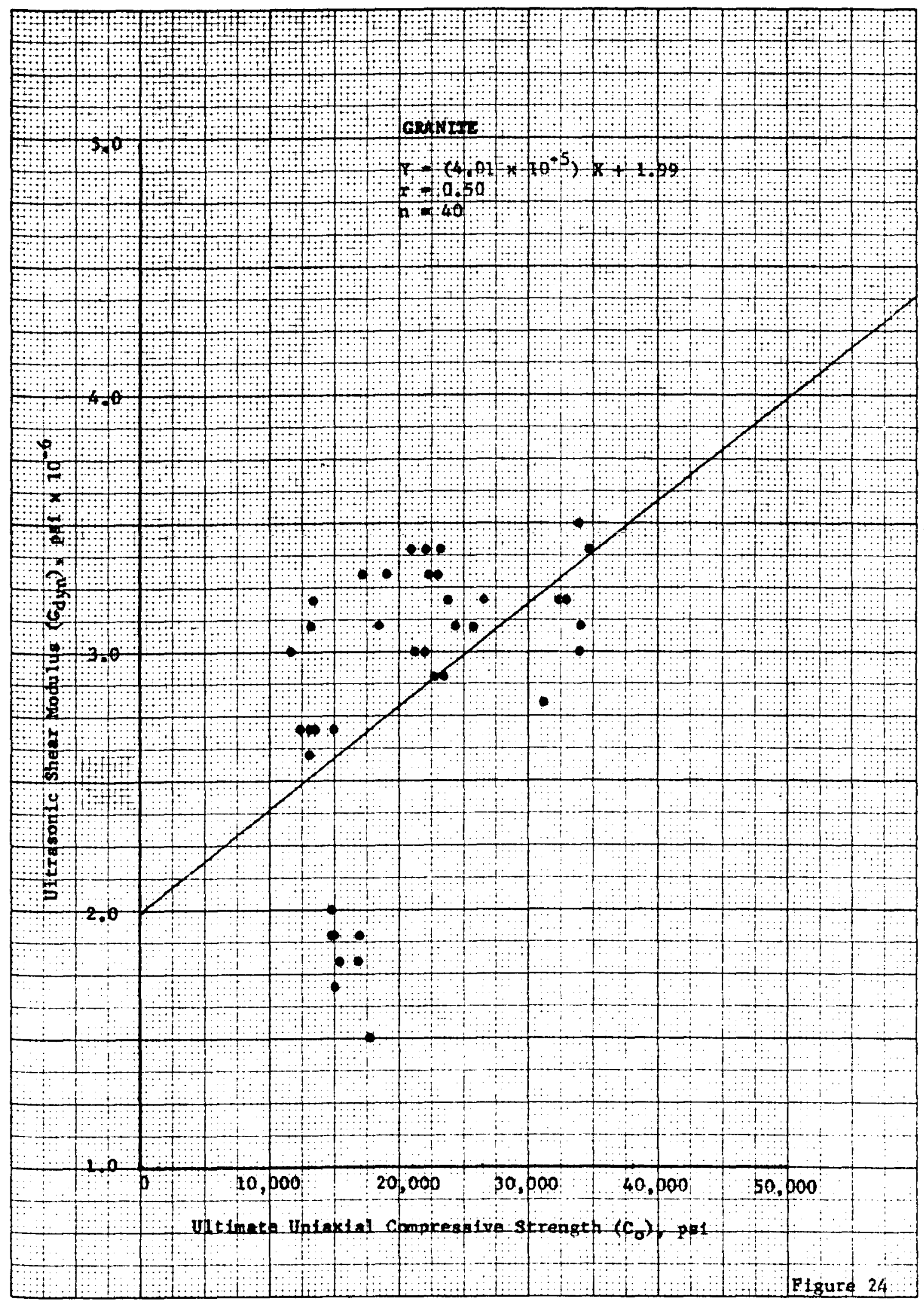









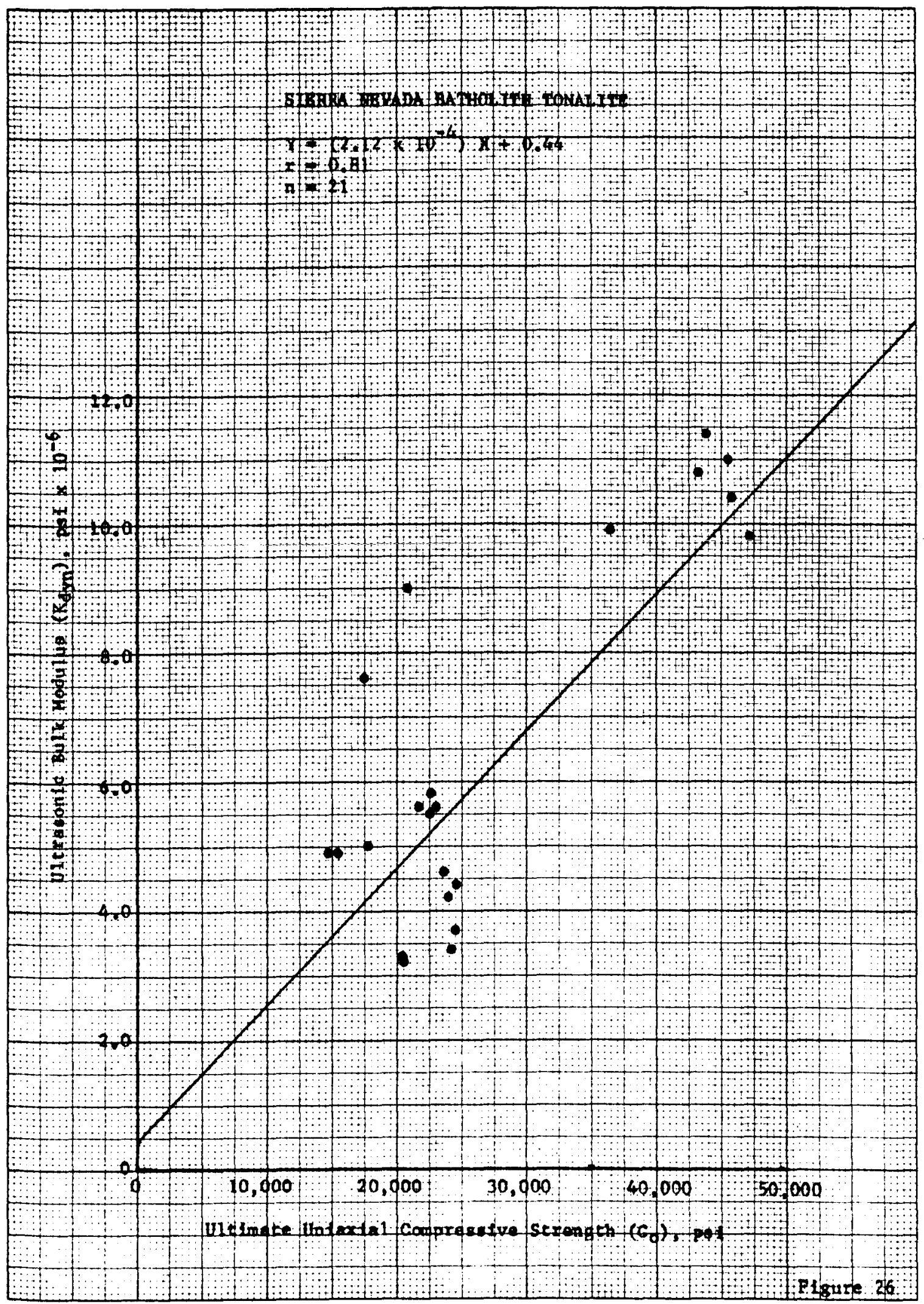




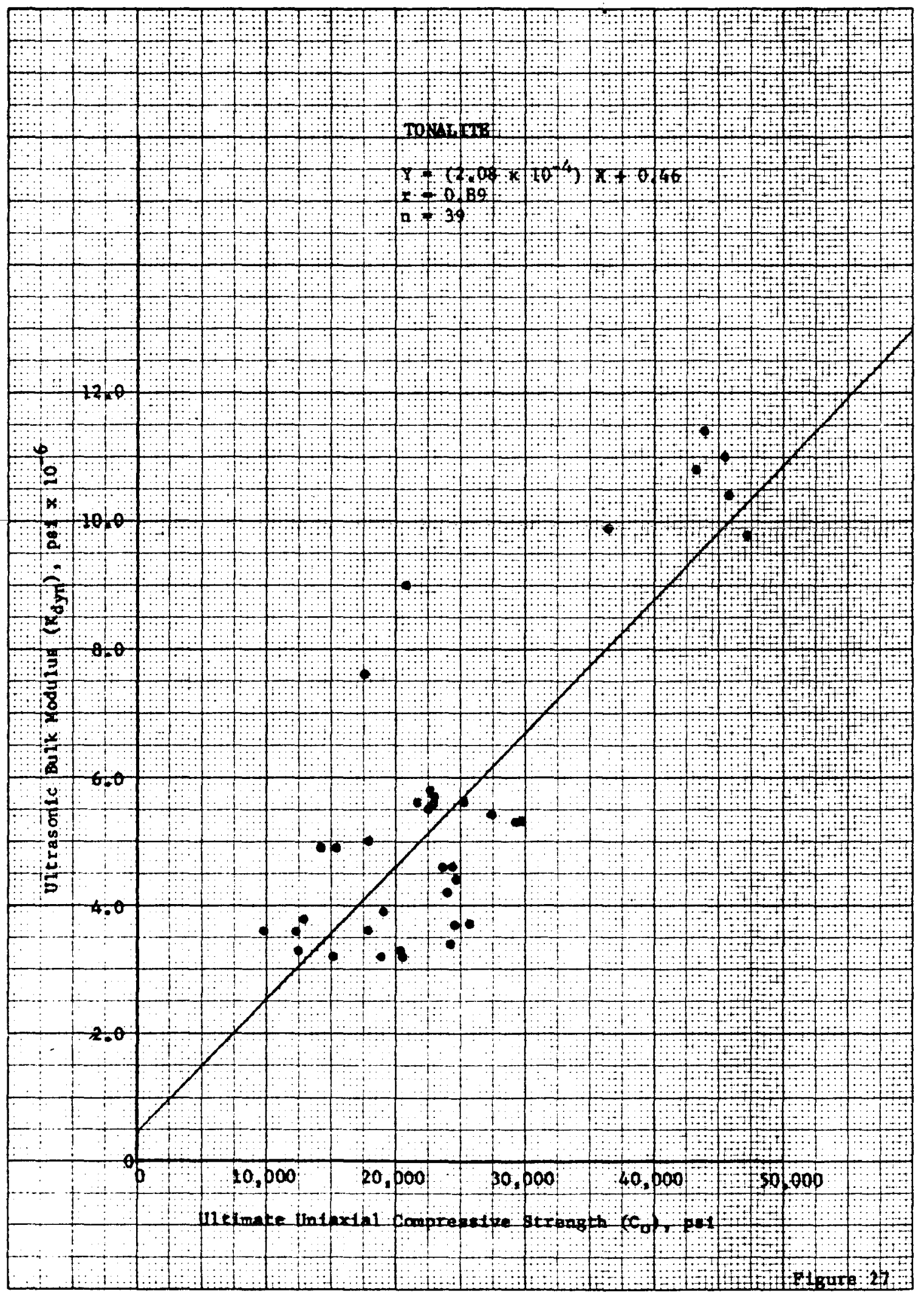




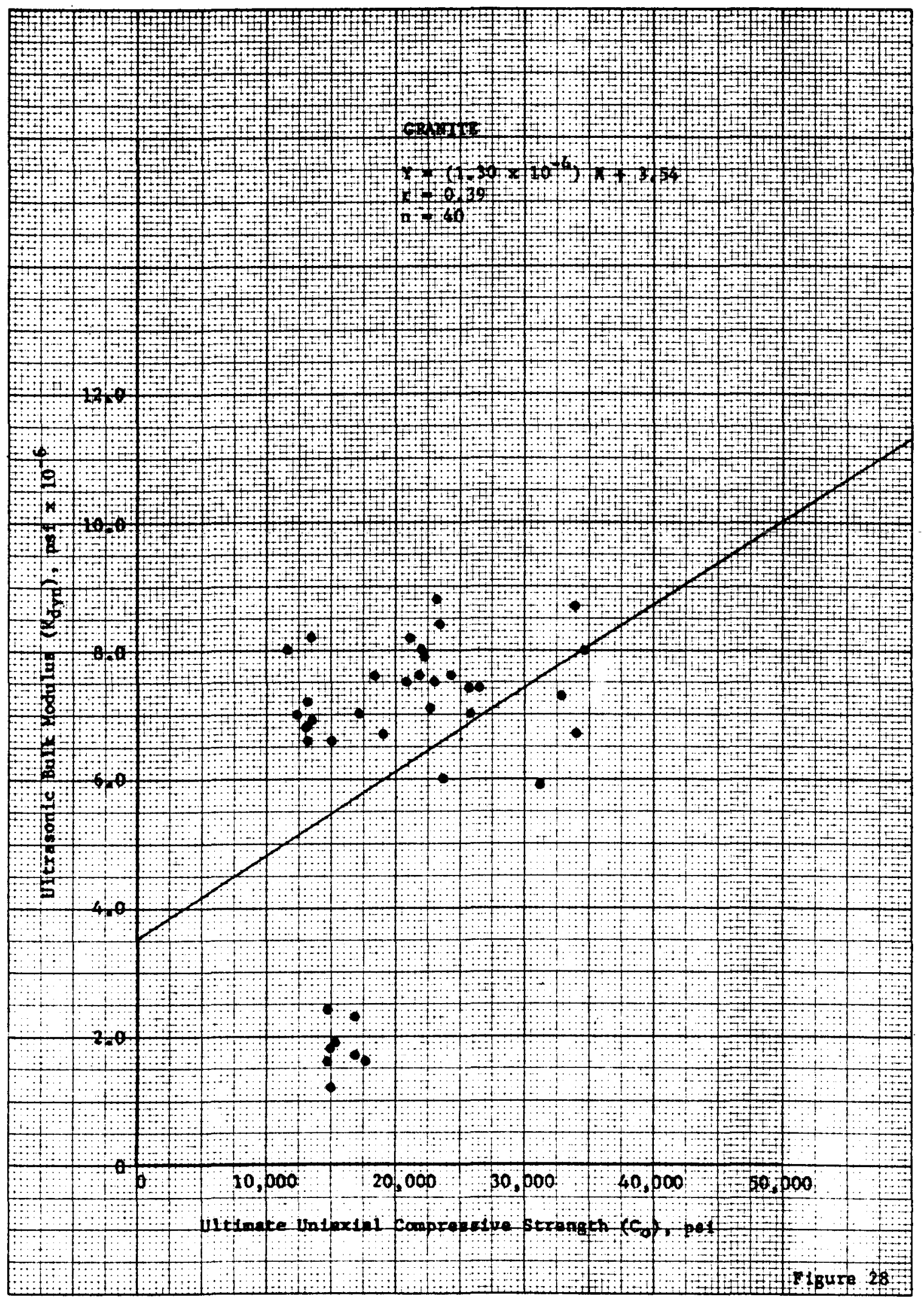




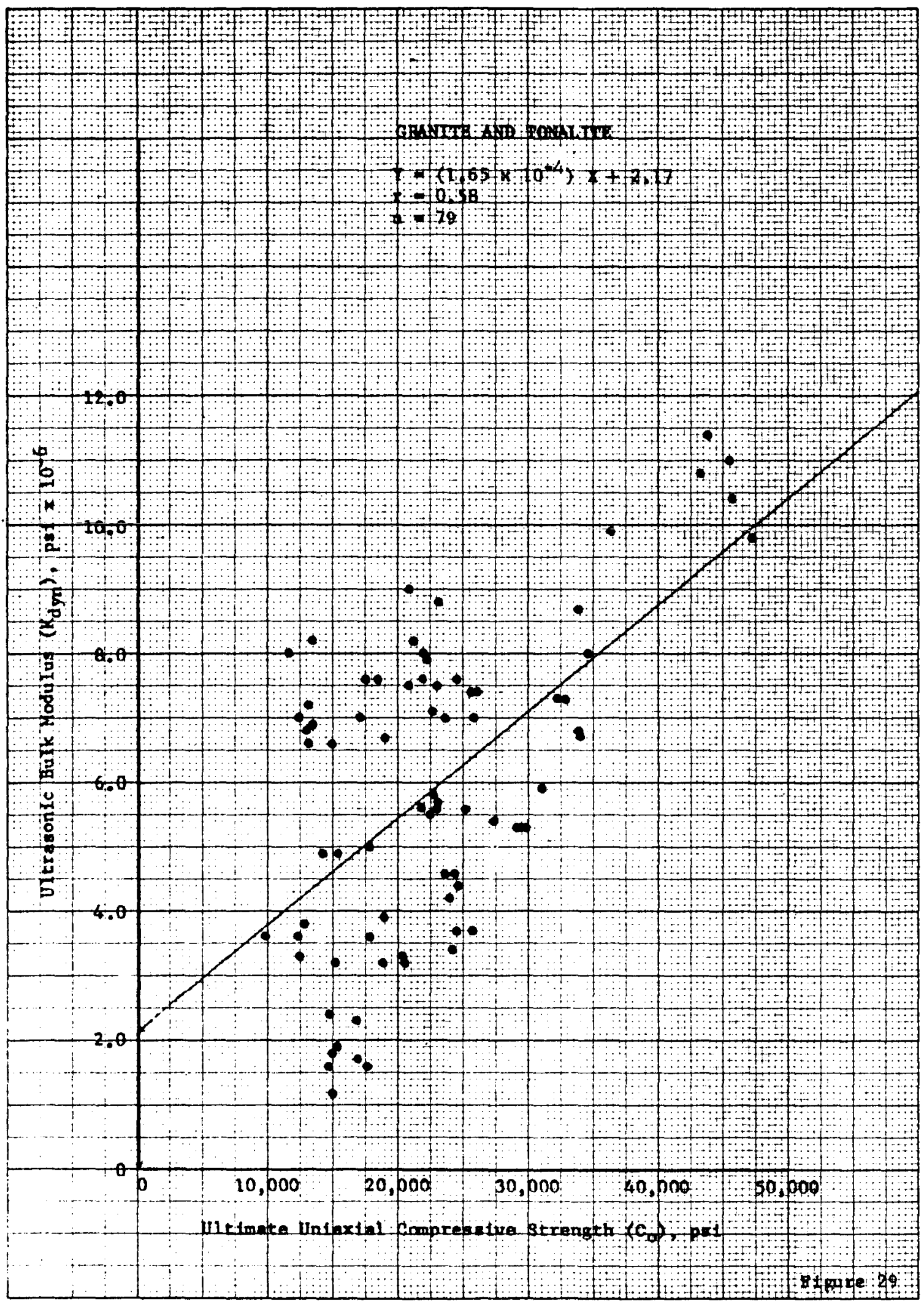


ahear pulse velocity $(0.86,0.87,0.49$, and 0.69 for Croup $1,2,3$, and 4 , reapectively) to alone justify the additional terting and computation necessary to the determination of ultrasonic ahear moduli. This is not to say, horever, that determination of ultraconic elastic moduli would be undesirable.

The same general trends prevalent in the correlation discussed previously $\left(C_{0}\right.$ versum $V_{p}, C_{0}$ versus $\left.V_{s}\right)$ were aldo common to correlations of ultimate strength veraue the various ultrasonic moduli. In particular, both groups of tonalite data yielded correlation coefficients of similar magnitude (Table 3) and scatter diagrams of a similar nature. This apparently reinforces the previous indication that variation in grain aize, rather than variation in mineraí composition and geologic bistory an allowed within the confines of a apecific rock type, appears to be of primary importance in the determination of the amount of scatter typical of correlations betreen various properties of this particular rock type.

Furthermore, examination of the correlation coefficients and ocatter diagrams determined for the number 2,3 , and 4 data groups indicated, for all three physical property comparisons involving ultimate trength and ultramonic elastic moduli, that the correlation of data for both rock types as aingle statiotical ample was undesirable from the point of view that such a procedure reaulted in an unnecensary sacrifice in quality of the scatter diagram and degree of correlation typical of the tonalite data alone rithout yielding an accompanying acceptable increase in quality of the scatter diagram and neture of correlation above those exhibited by the granite data alone. 
$C_{0}$ Veraus $v_{\text {dyn }}$. Scatter diagrams illustrating the relationahip observed to exint betreon ultimate uniaxial compresnite atrength and ultrasonic Poinson'a ratio for the four data groupe used in this inventigetion are given in Figures 30 through 33.

Corrolation coefficienta determined for these data group (Table 3), were in general, very 10r, and in all canes but one, were leas than the critical values (given in Lppendix II), indicating no significant degree of linear ansociation betreen the tro rariablea. The coefficient: wore $0.49,0.20,0.33$, and 0.24 for data groupa $1,2,3$, and 4 , reapectively.

Figures 30 through 33 further indicate the lack of linear ansociation betroen the two rariablea under exemination, and, in addition, reveal that the higher of the four correlation coefficients ore their larger magnituden solely to the prenence of a fer points (eight) of quentionable validity (unusually lor values of ultranonic Poisson'a ratio) without which these coefficients rould be even less oignificant.

$\mathbf{E}_{\text {tan }}$ Veroue Ultrasonic Pulne Velocities $\left(v_{p}\right.$ and $\left.v_{g}\right)$. Figures 34 through 37 phyoically illustrate the relationship existing betreen values of tangent Young' modulus of elasticity (atatic) and values of ultrenonic compreanional pulse velocity as determined in this study. Figuren 38 through 41 depict the relationship exinting betroon values of tangent Young' modulus and values of ultrasonic chear pul we velocity.

Intereatingly, the eight correlatione (four date groupa) determined for these tro particular pairs of variables rere all quite 


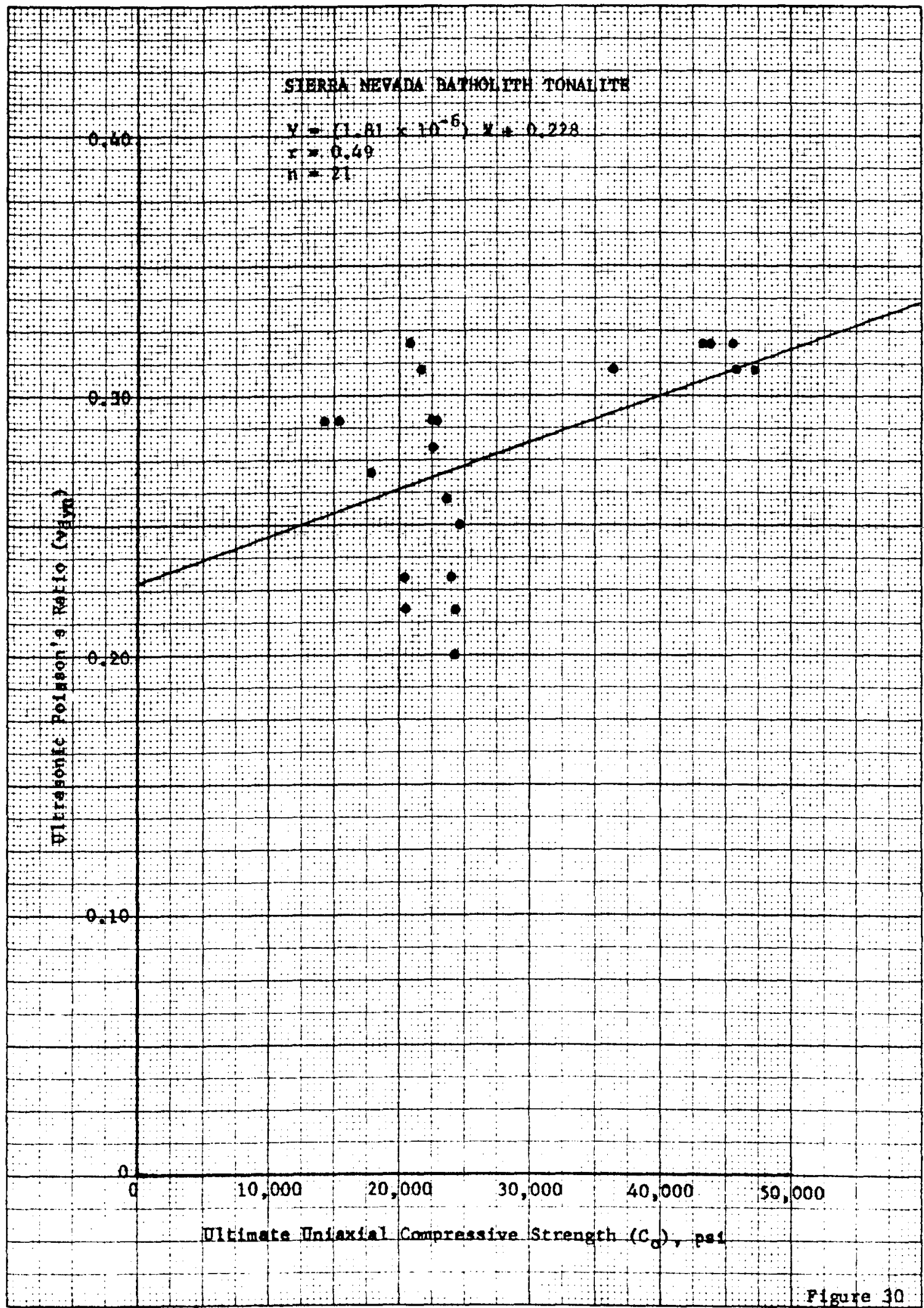




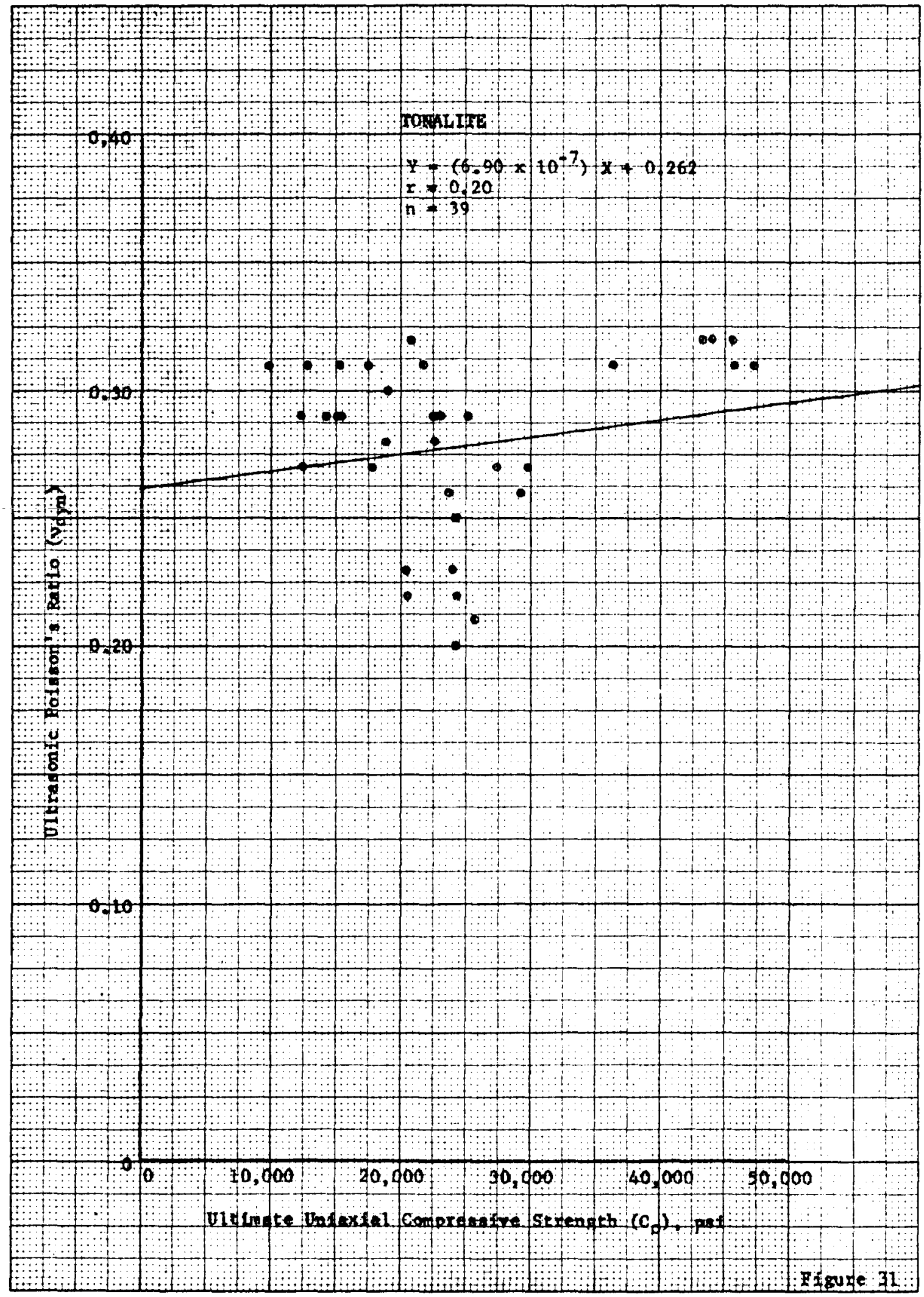




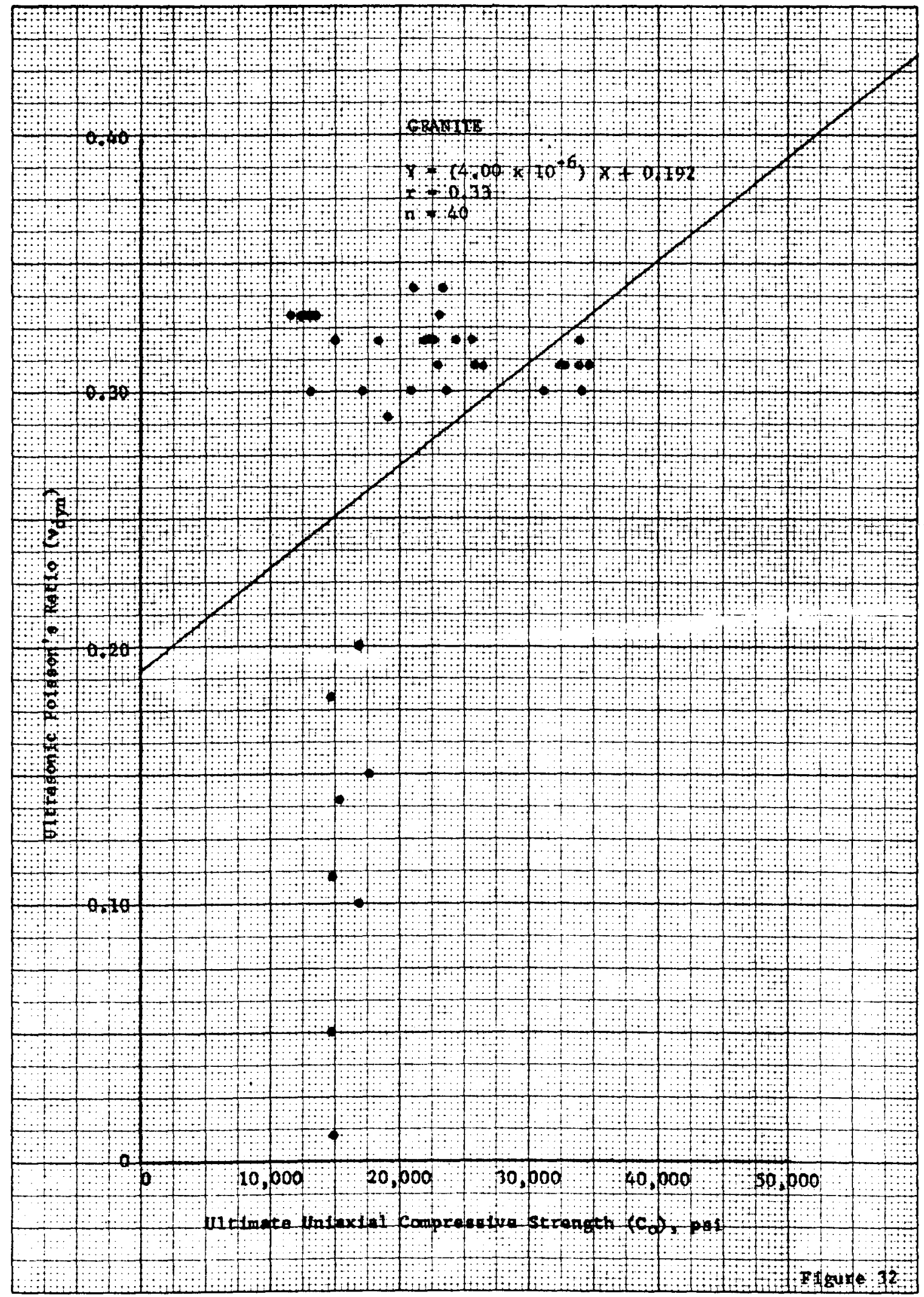




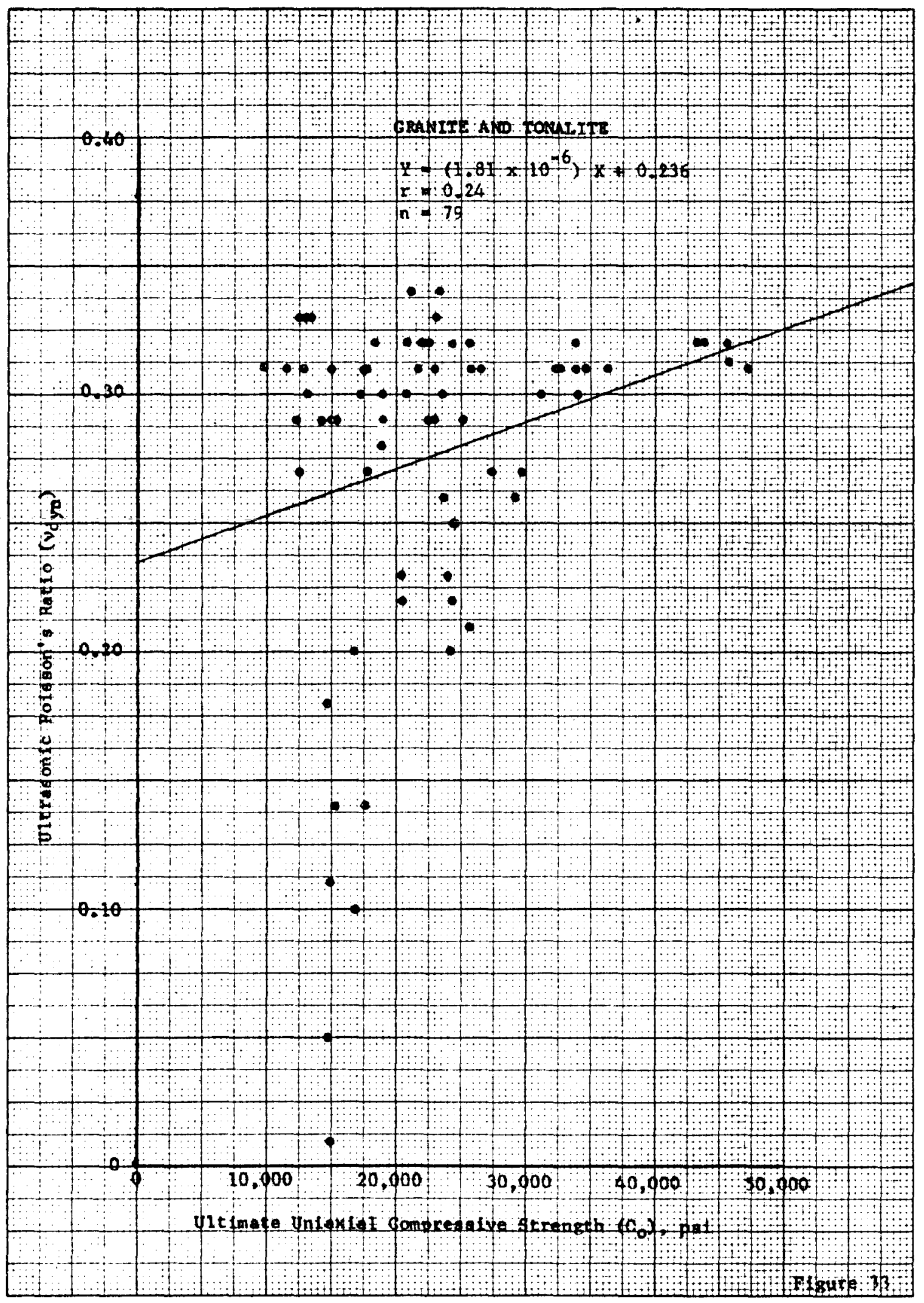




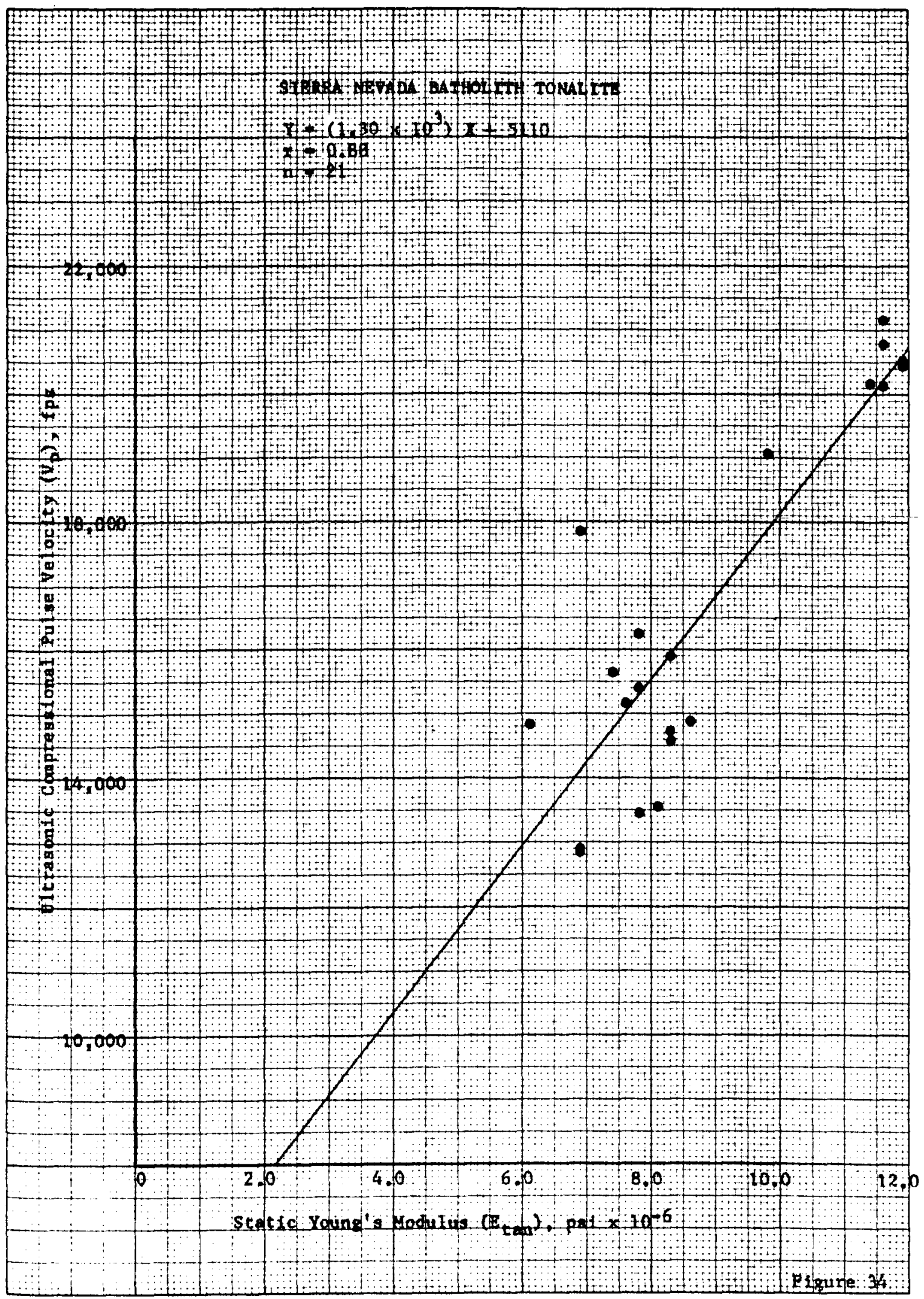




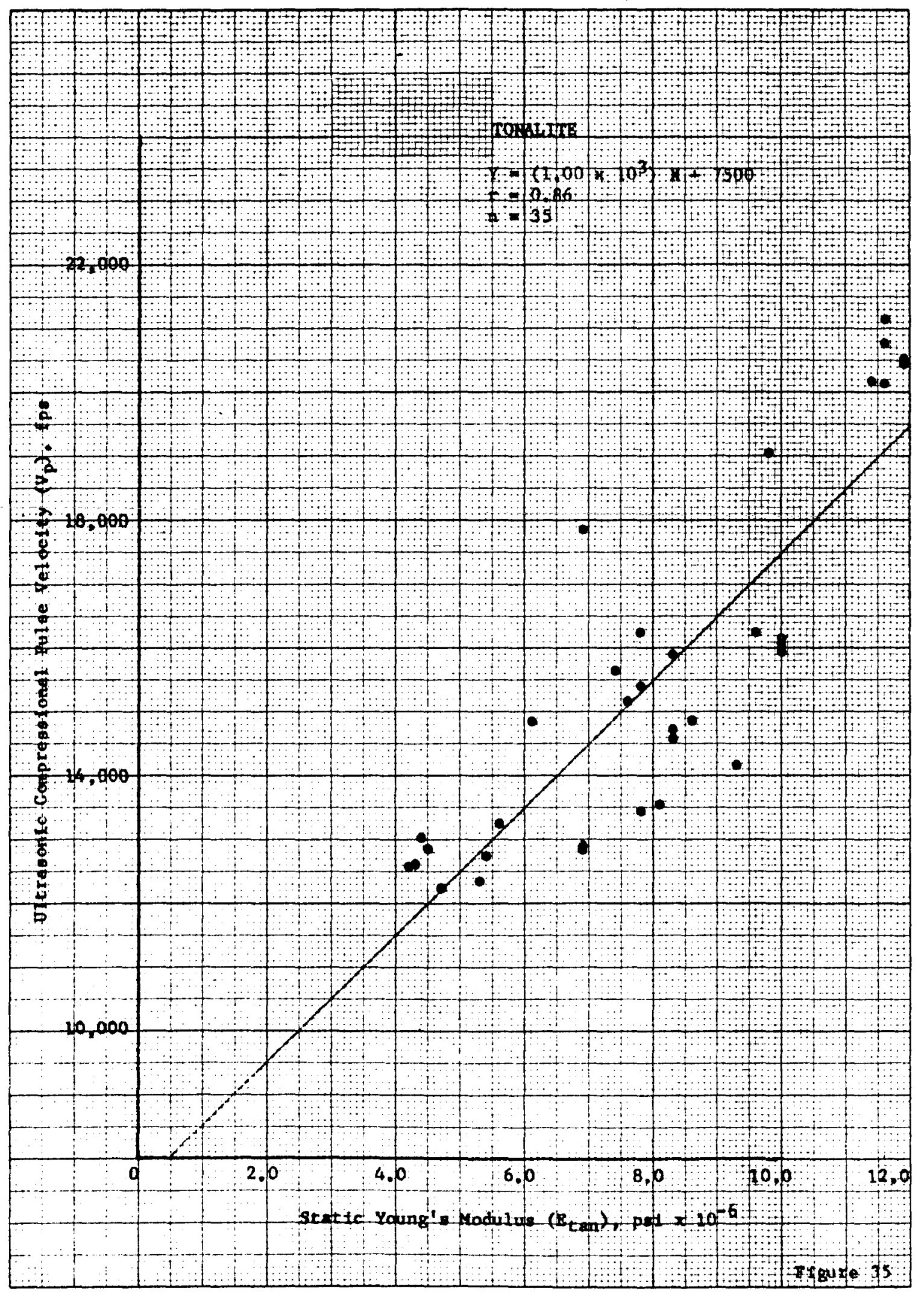




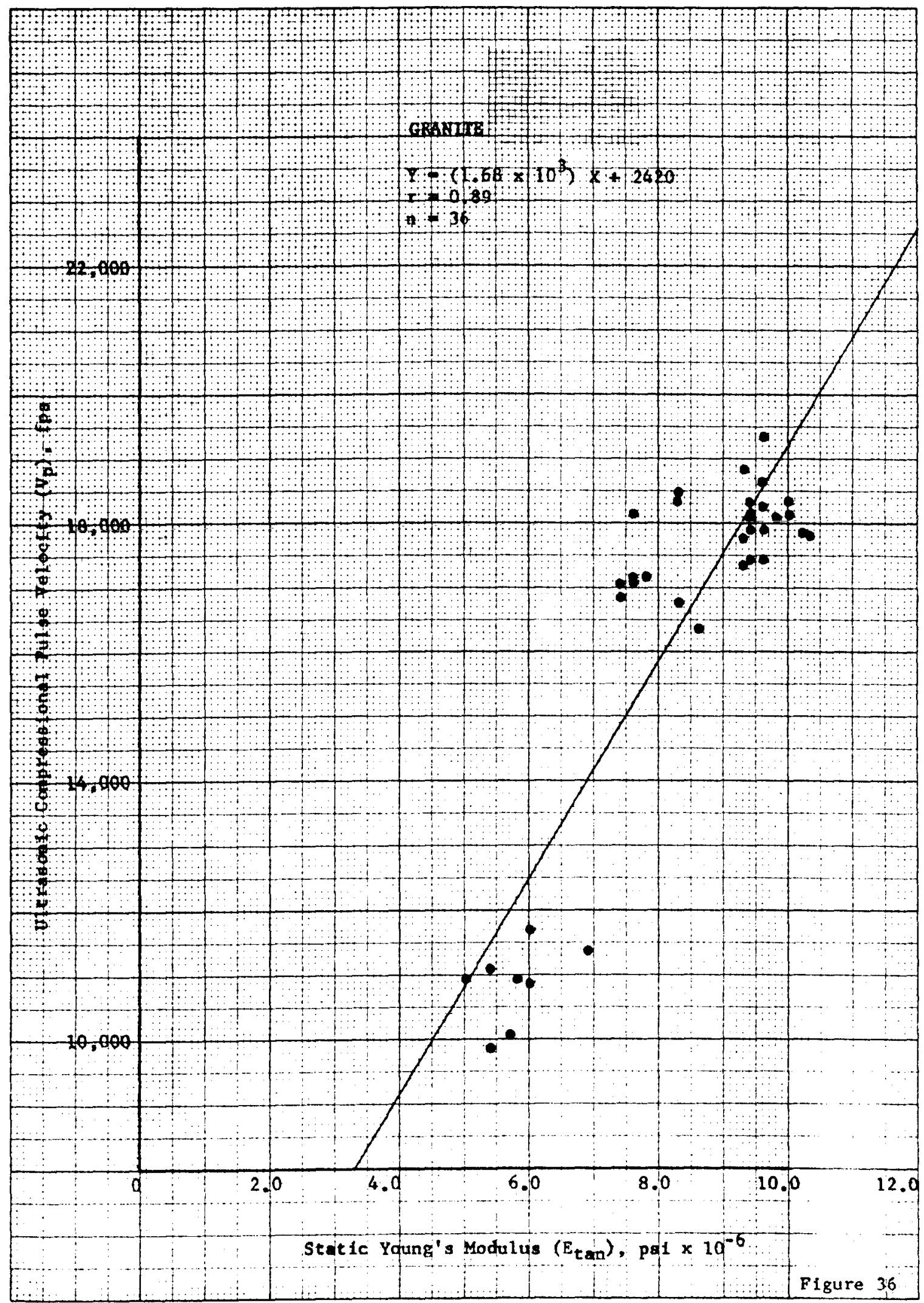




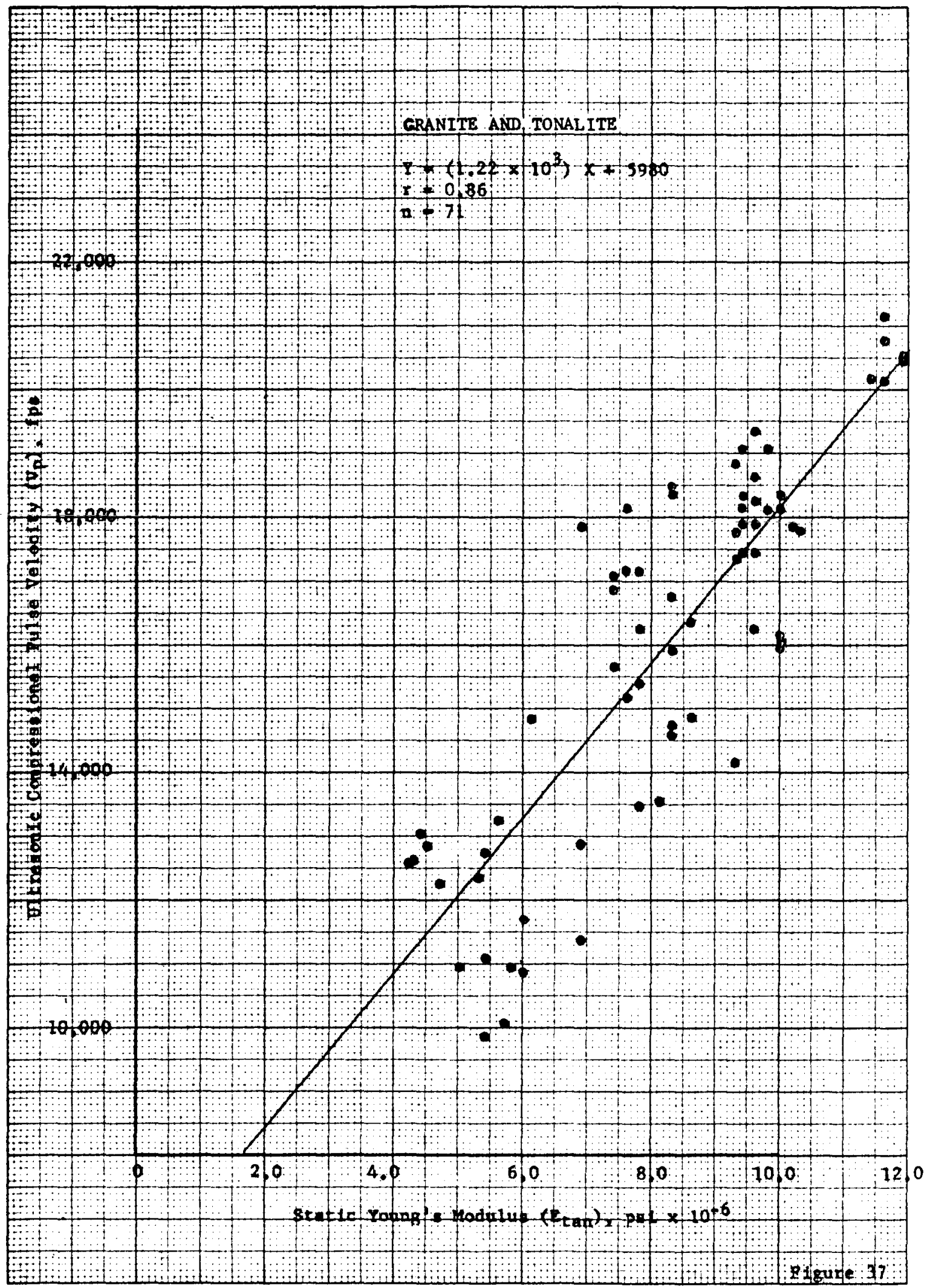




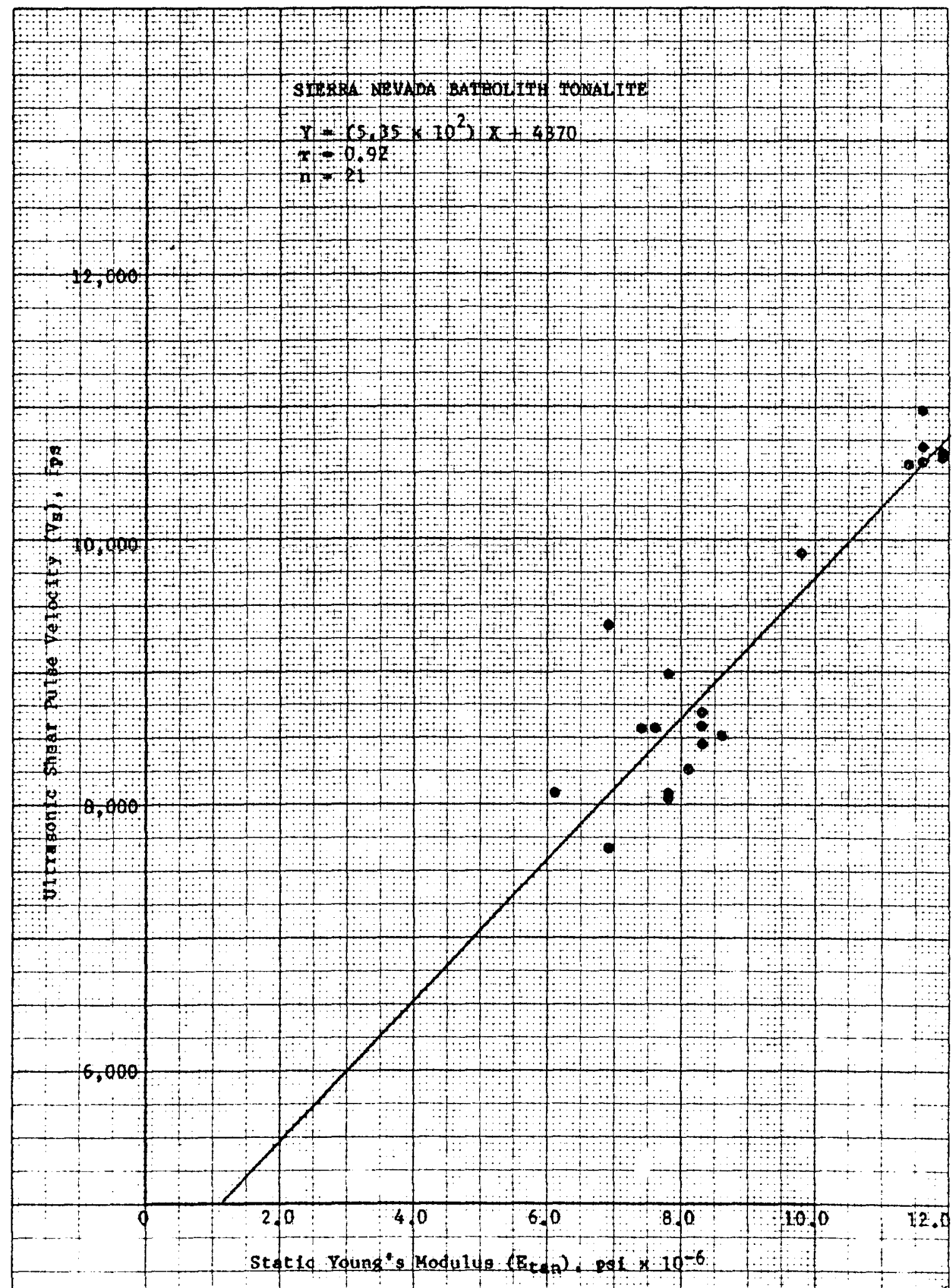

41 garte 38 


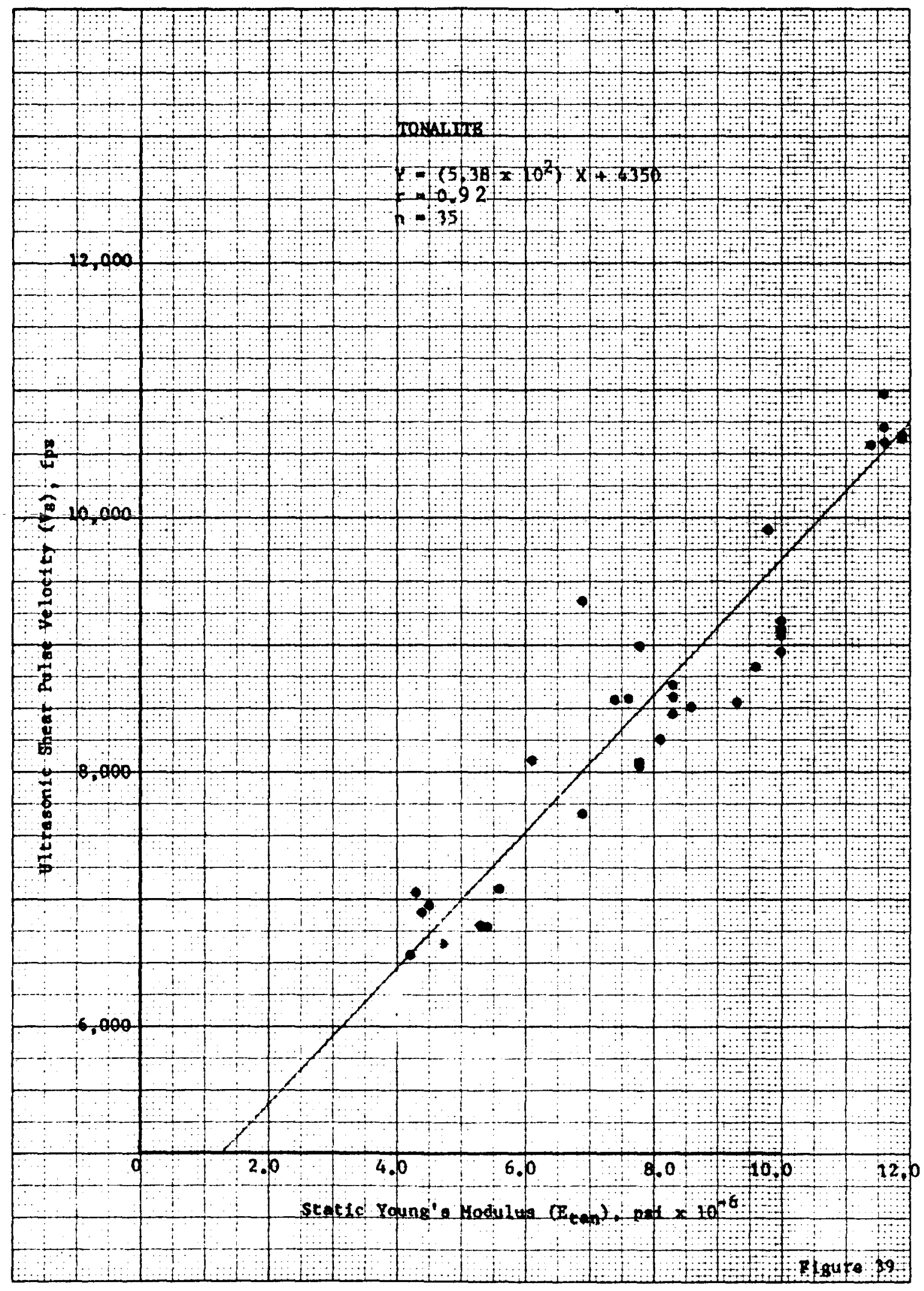






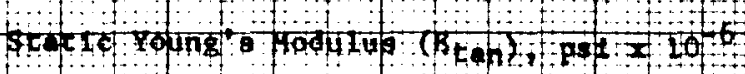

Figune ta 


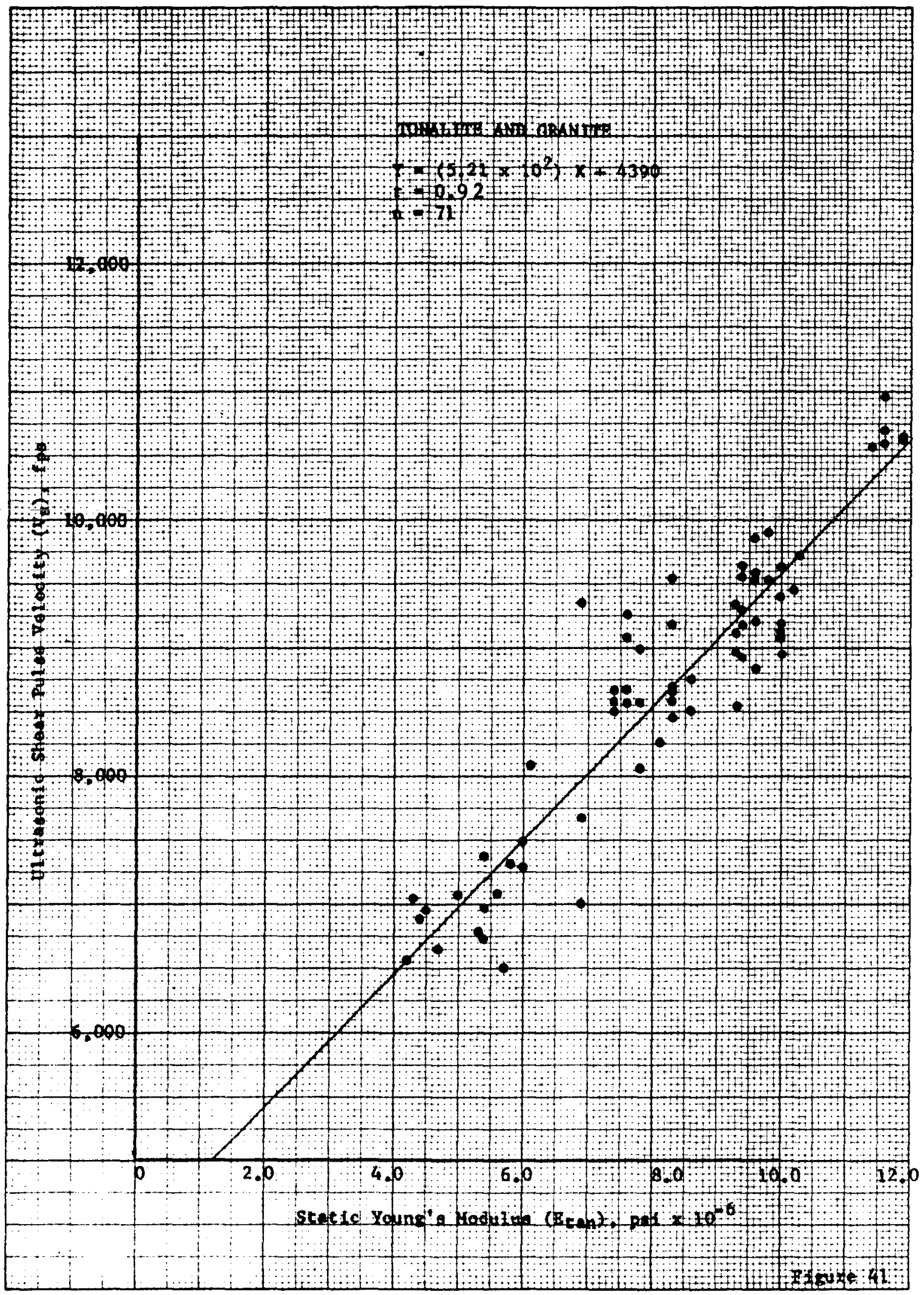


aignificant (correlation coeficients were much larger than the correaponding critical ralue as given in Appendix II) and rery aimilar in nature, the quality and orientation of the relationship determined for the granite data alone being very nearly the came an those determined for the tonalite data alone, for comparable pairs of properties. This trend of aimilarity, which incidentally will be obaerved to exist generally throughout the correlations of tangent Young's modulus with the other various ultresonic propertiea, was somewhat of a reveraal of the earlier trend noted for correlatione of ultimate unlaxial compressive strength with the various ultrasonic propertiea wherein the correlations for the granite relationshipa were frequently insignificant and noticeably inferior to those of the tonalite data. This "change" rould appear to be a aignificant indication that the factora which contribute to ultimate uniaxial compreasive strength characteriatics and to the nature of the ralues of tangent Young' modulua of elasticity typical of a particular rock type do not necessarily contribute to the same propertios of a similar rock type in the same manner.

$A$ comparison of the acatter diagrams and correlation coefficients (Table 3) determined for the four groups of data representing each pair of physical propertion reaulted in tro additional general observations (1) correlations determined for the Group 1 and Group 2 tonalite date rere similar both in orientation and degree of acatter, reinforcing the previous indication that variation in grain size within the particular rock type, rather than variation in mineral composition and geologic hintory as allored rithin the confines of the apecific rock type, was a primary influence upon the 
degree of acatter typical of the data plota for this rock type, and (2) amalgamation of the data for the tonalites and granites into a alngle group (Group 4) and correlation of this data as ach yielded a satter diagram and correlation coefficient which were of a nature and quality very similar to those determined for the paront data groups (Groupe 2 and 3). This would appear to indicate, for the particular variables being examined, that auch an analgamation of data for such geologically aimilar rock type rould not necesnarily reault in correlations of a quality oubotantially lower than the correlations determined for data grouped and correlated by individual rock type.

$\mathbf{E}_{\tan }$ Veraua Ultrasonic Moduli $\left(\mathbf{E}_{\mathrm{dyn}}, \mathrm{G}_{\mathrm{dyn}}, \mathrm{K}_{\mathrm{dyn}}\right.$ ). Scetter diagrams illuetrating the general relationahip found to exist betreen tangent Young' modulus of elasticity ( $\left.E_{t a n}\right)$ and ultranonic values of Young' modulus of elasticity $\left(E_{d y n}\right)$, shear modulus $\left(G_{d y n}\right)$, and bulk modulue $\left(\mathrm{K}_{\mathrm{dyn}}\right)$ are given in Figure 42 through 45,46 through 49 , and 50 through 53 , renpectively.

Nature and degree of linear correlations obtained for correaponding data groups jielded for all three paira of variables rere quite similar, probably due, as wan the case with ultimato uniaxial compressive strength, to similarity in origin of the various values of the three ultrasonic elastic moduli ( $E_{d y n}, G_{d y n}$, and $\left.K_{d y n}\right) . \Delta 11$ rere computed from equations involving value of nltrasonic ahear and compreasional pulae velocitien and apecific gravitien of the individual apecimene.

The physical property correlations determined for those pair of variables involving ultrasonic moduli rere generally quite good. 


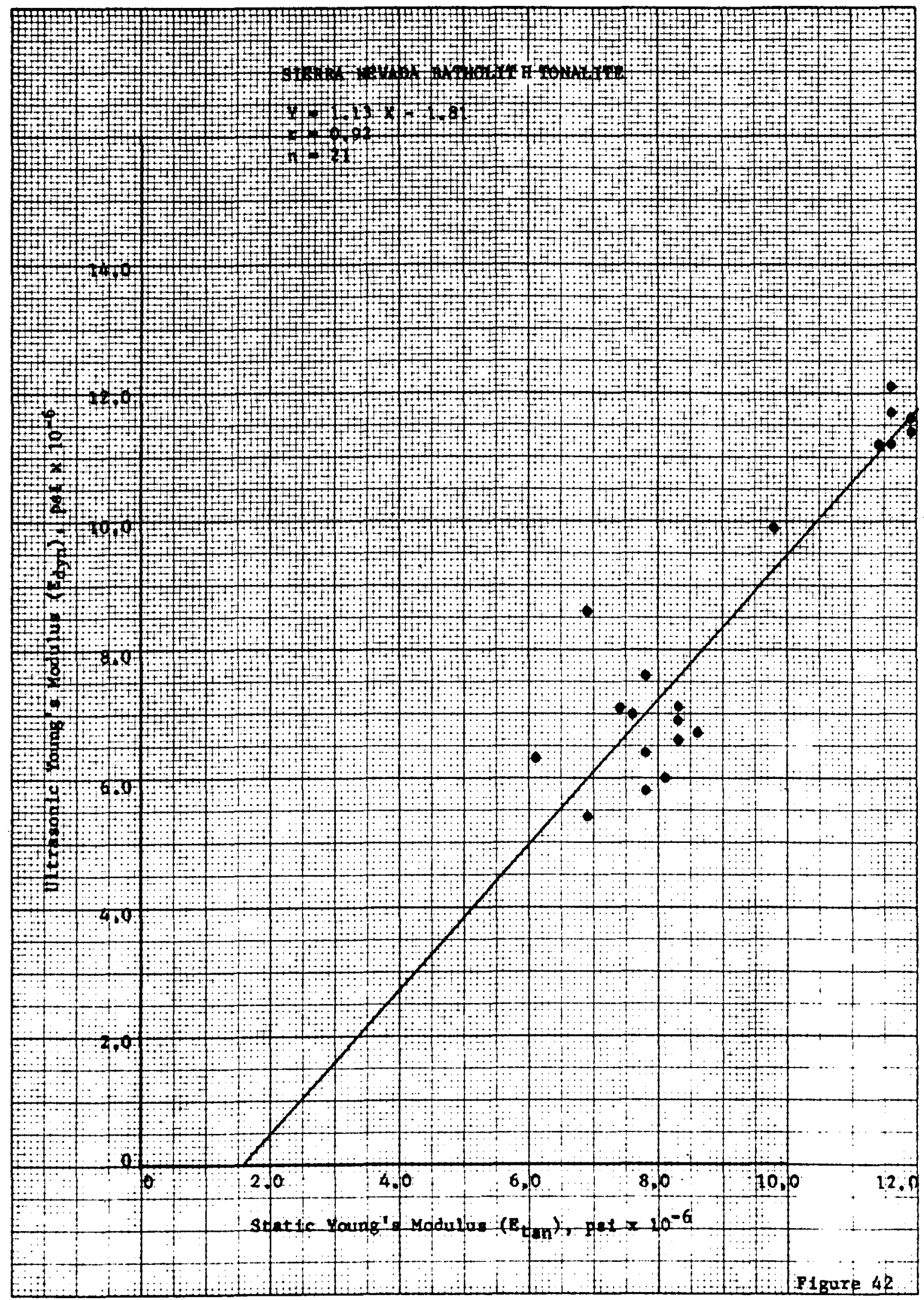




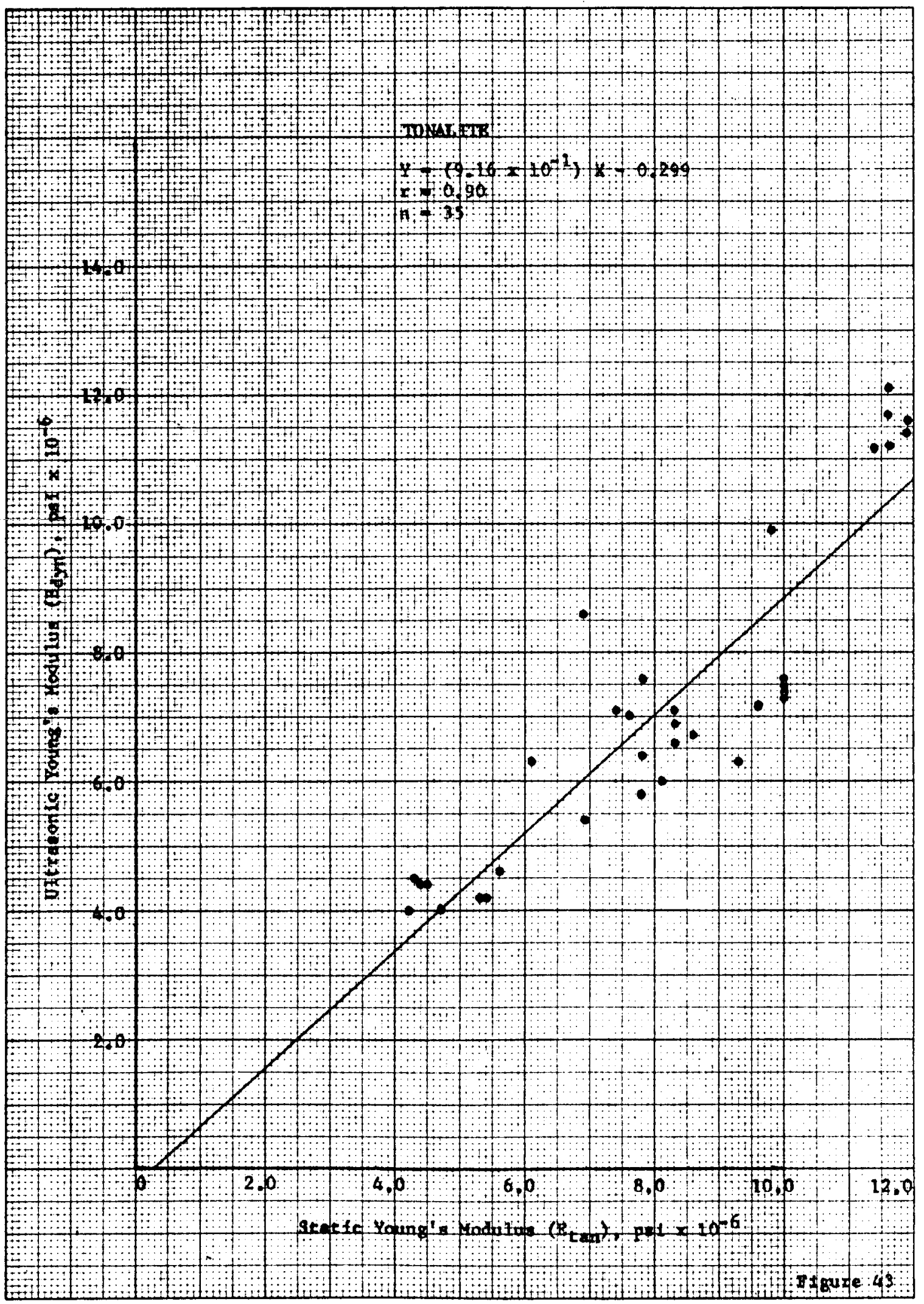




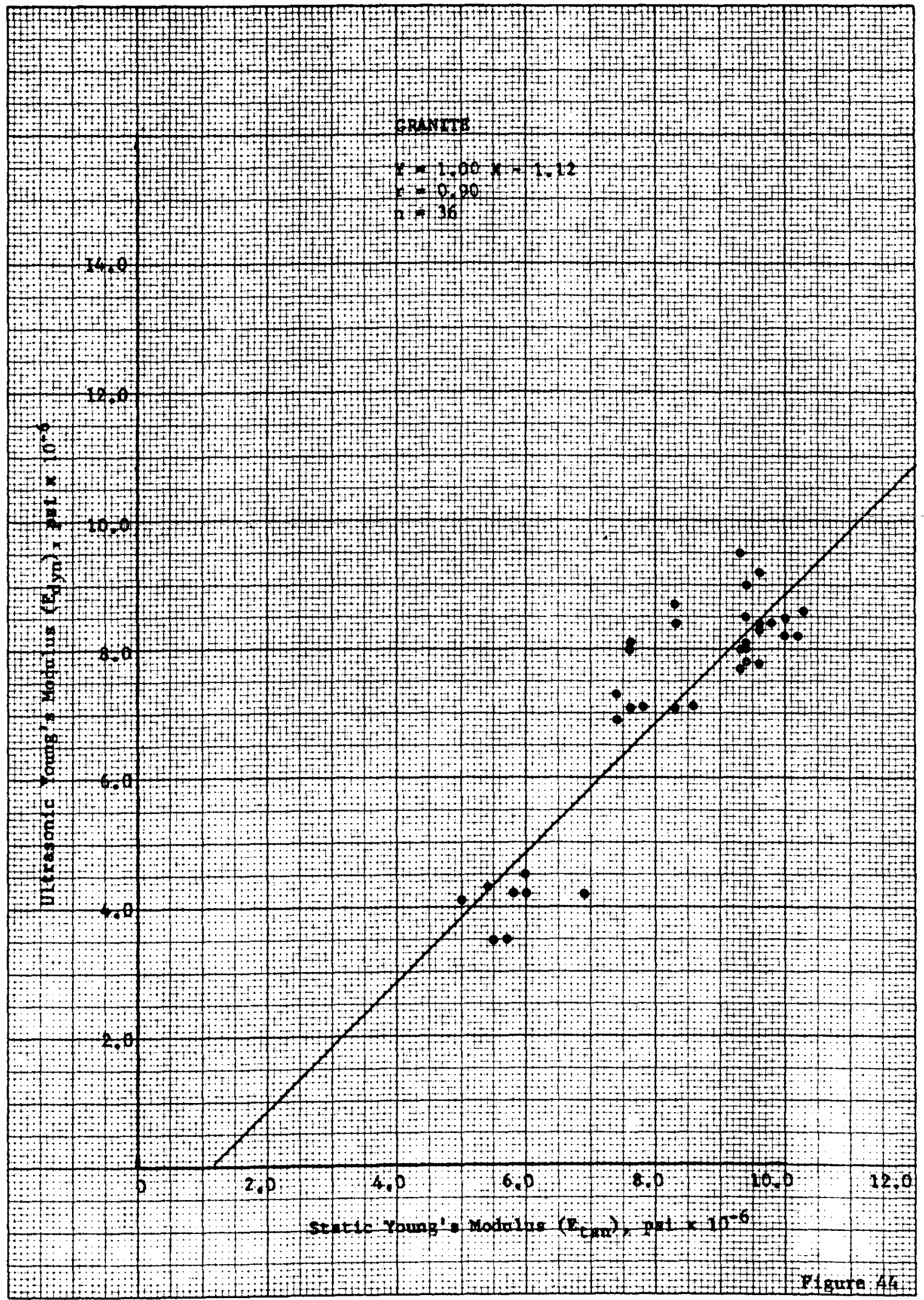









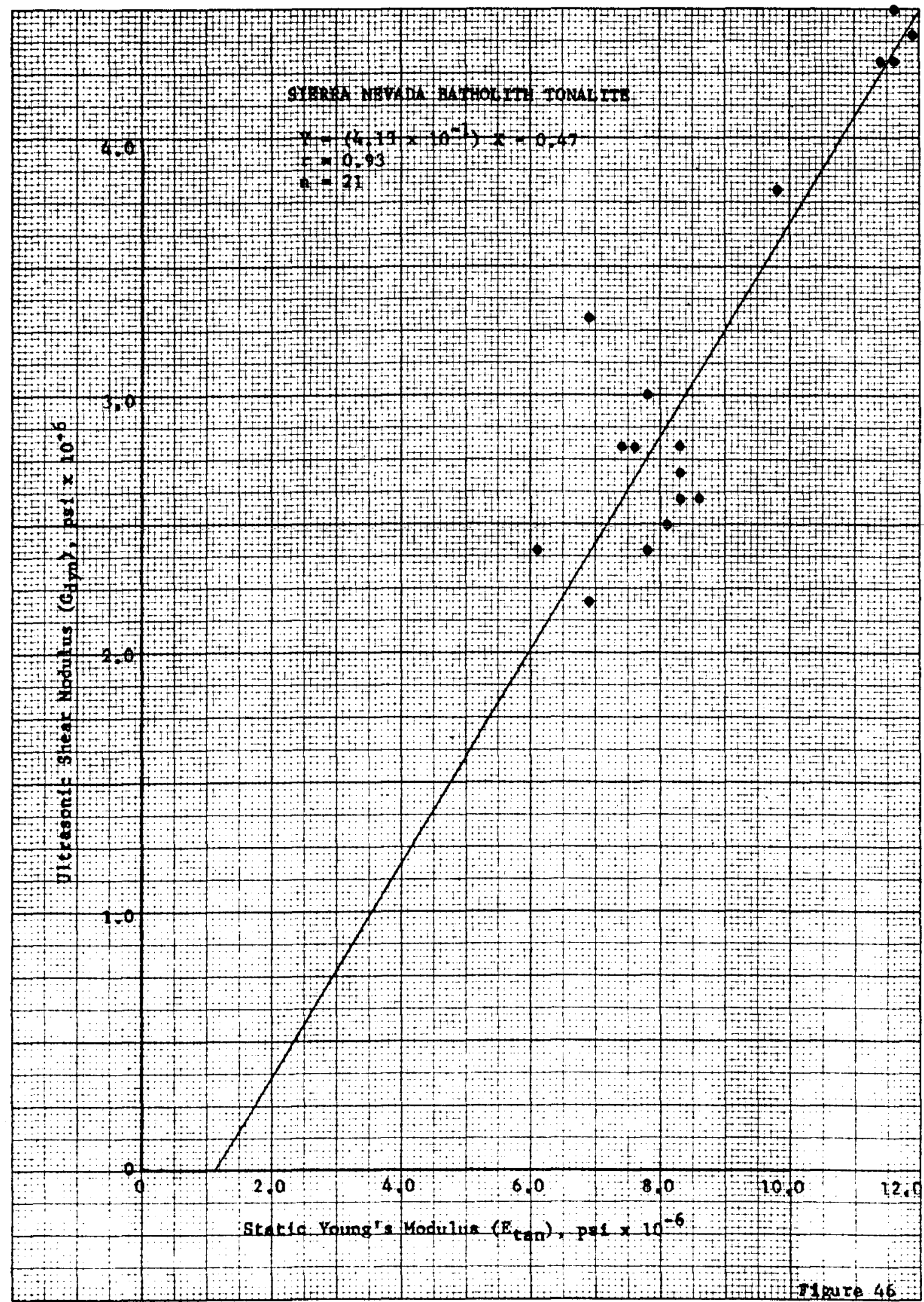




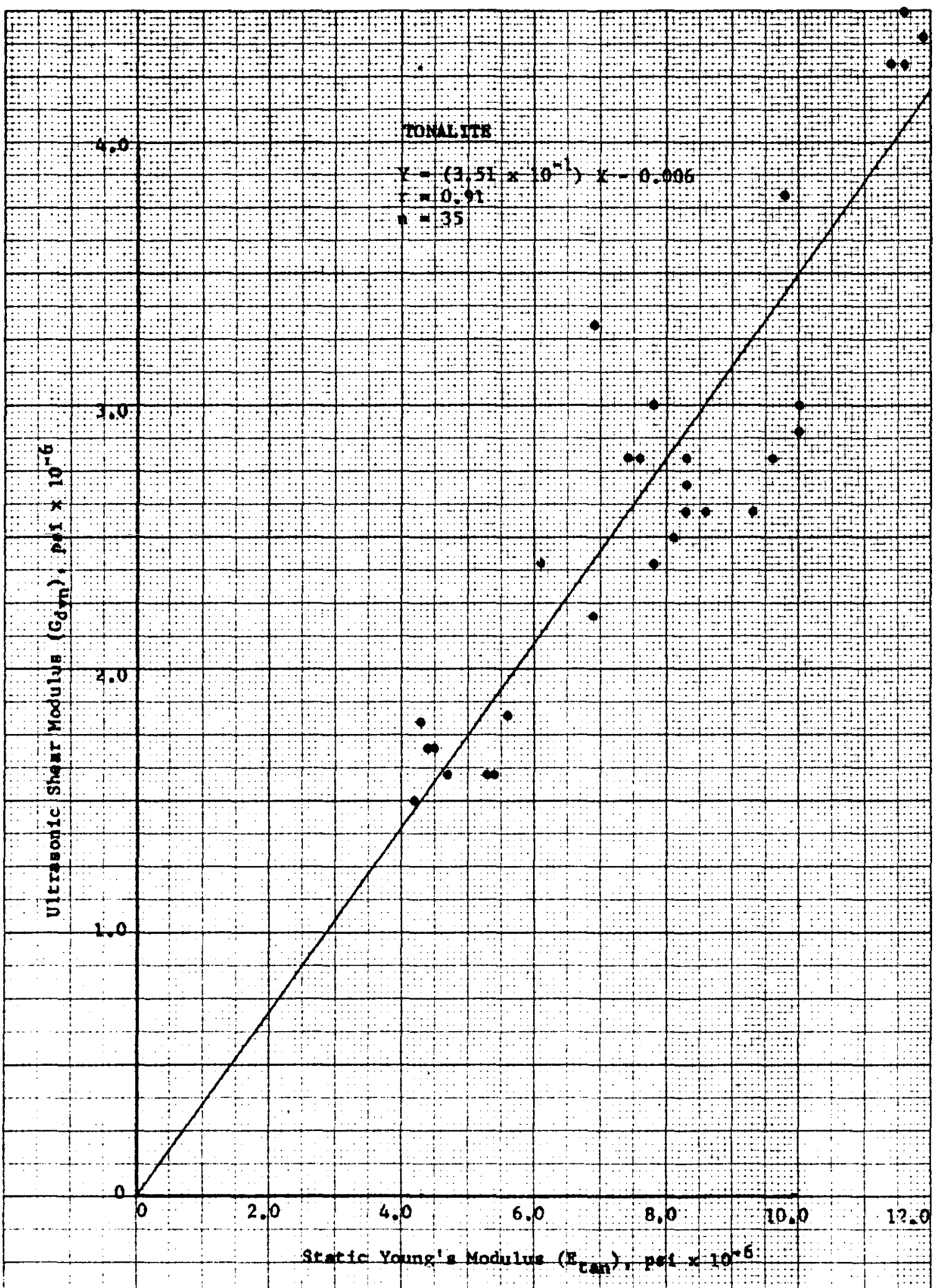

pligune 47 


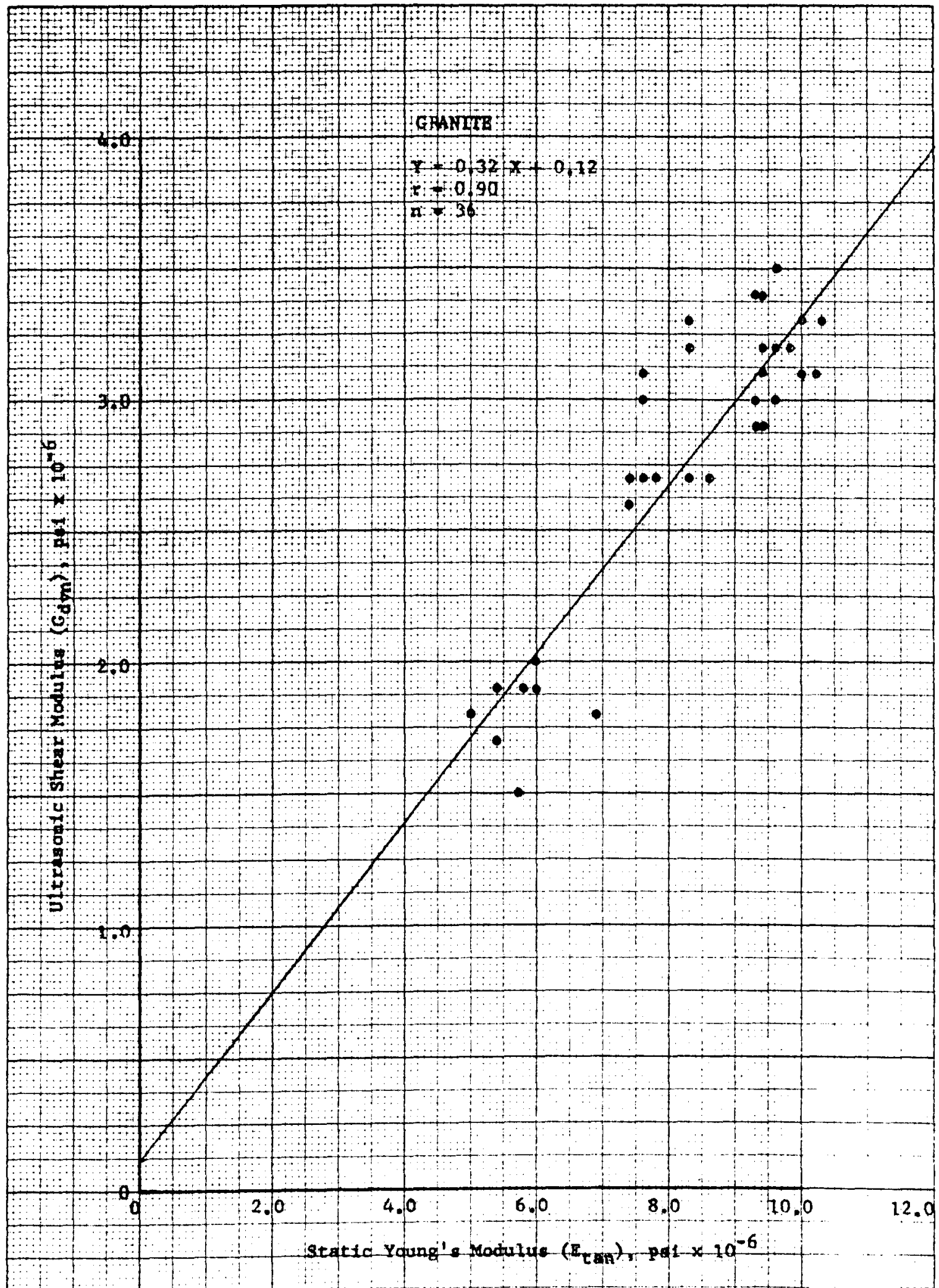

Figure 48 


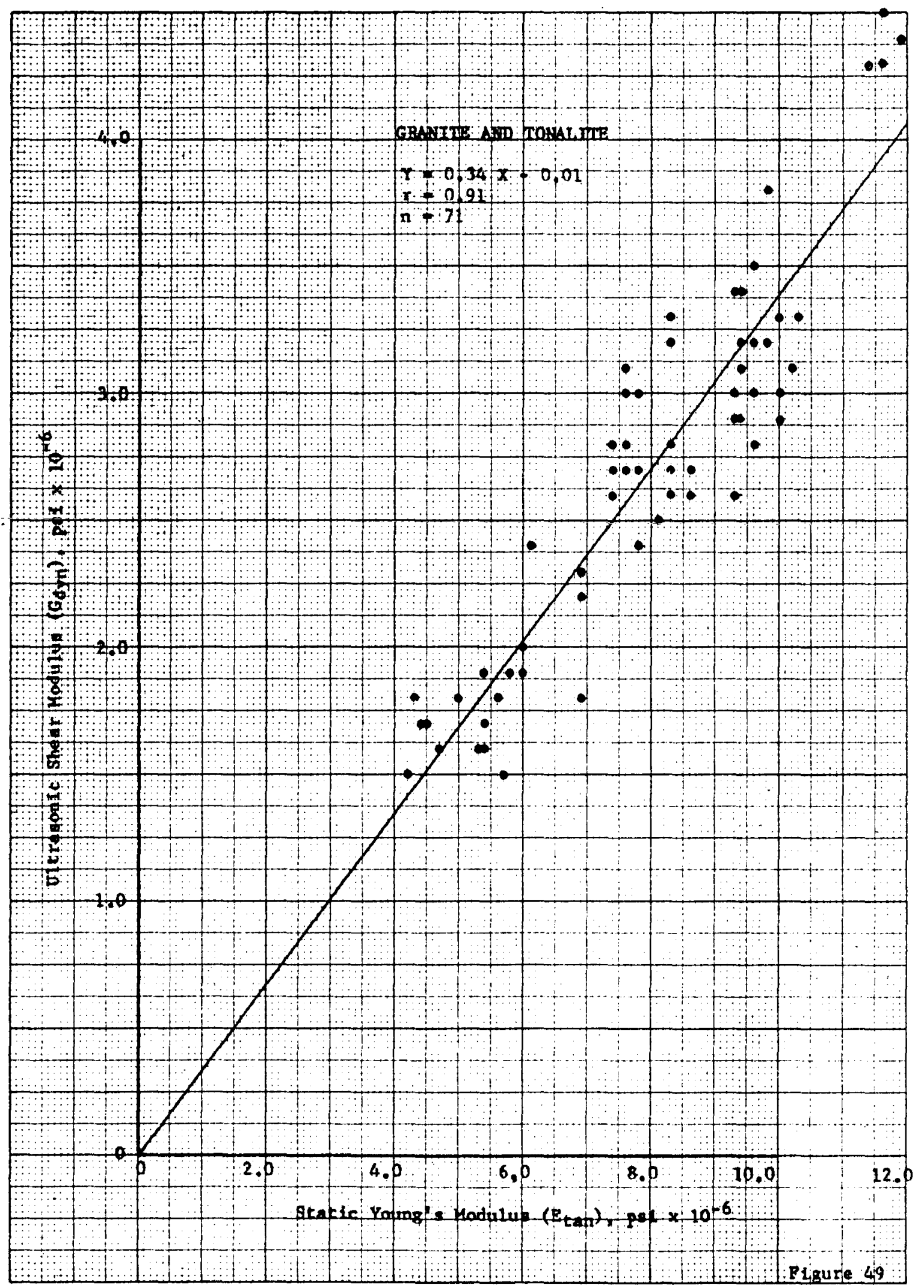




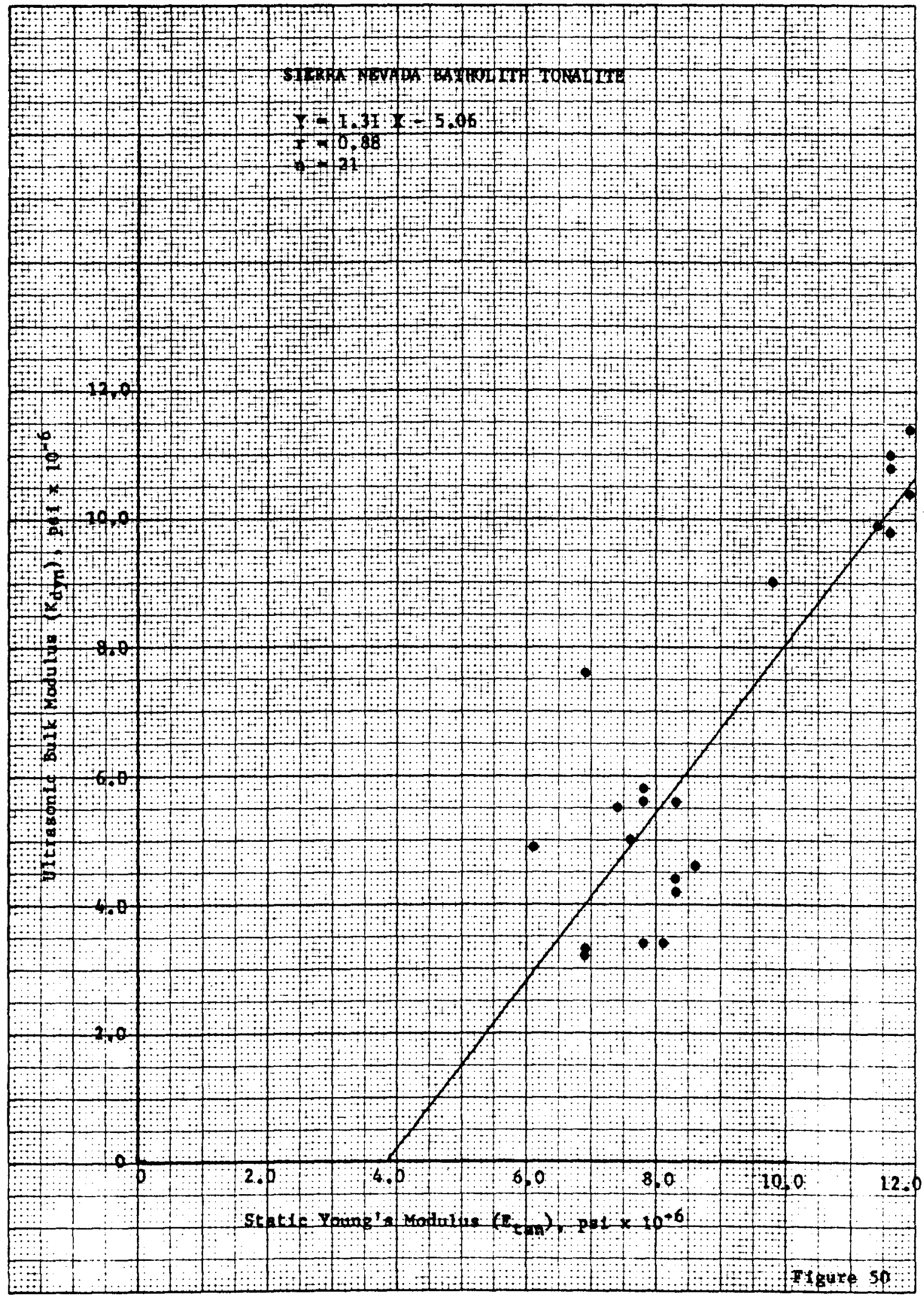




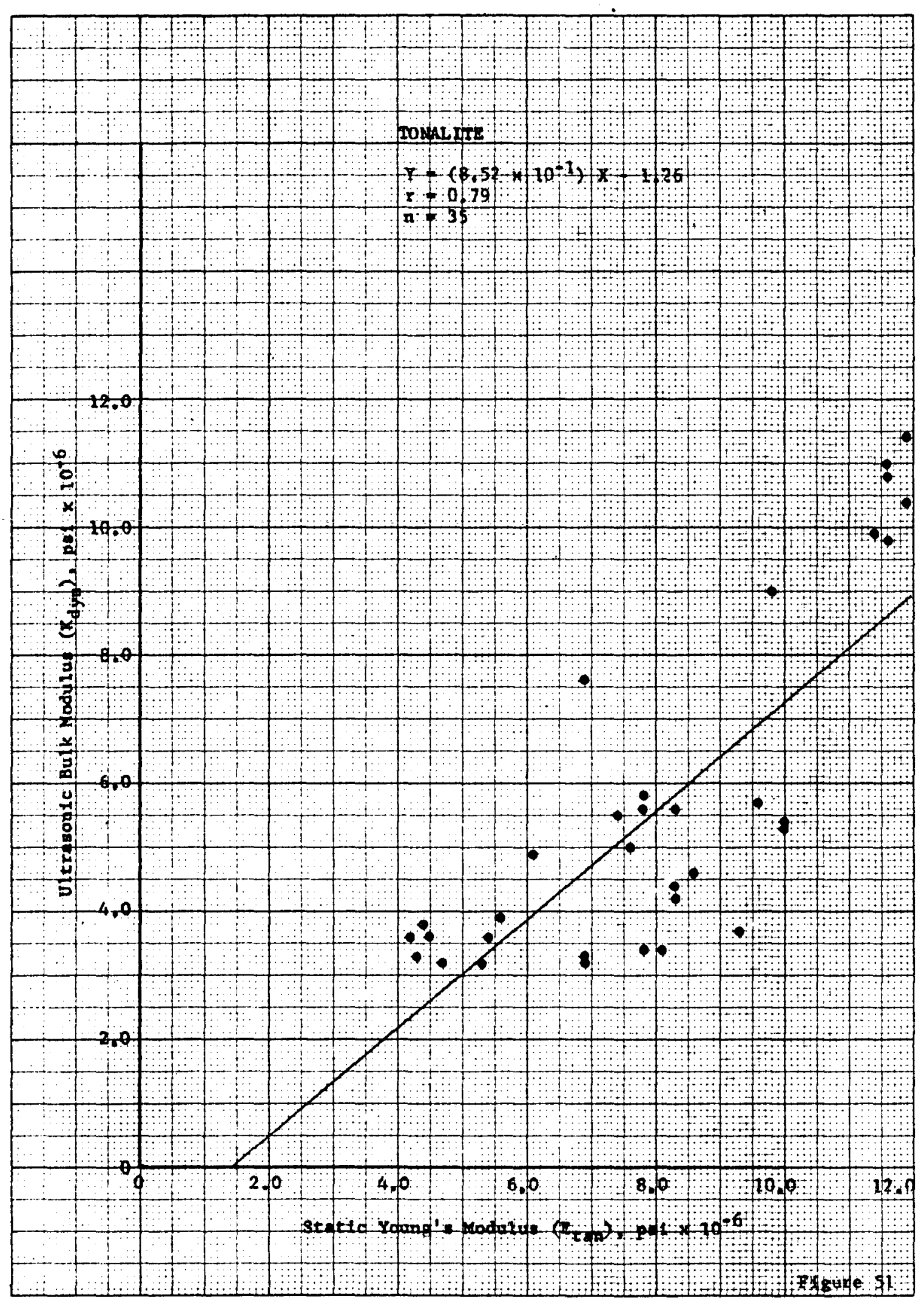




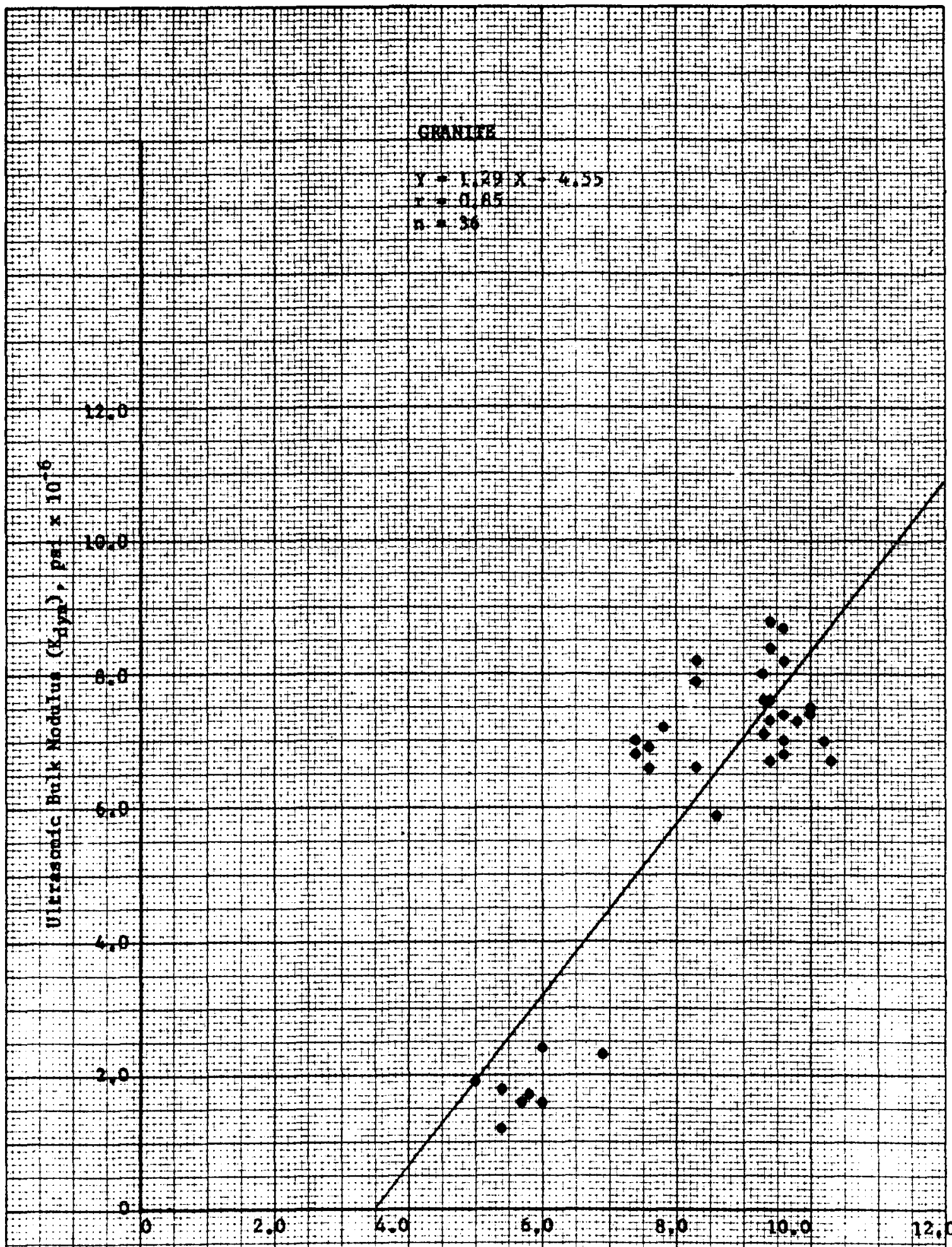

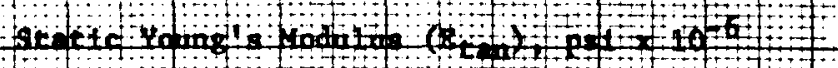

itguta $\$ 2$ 


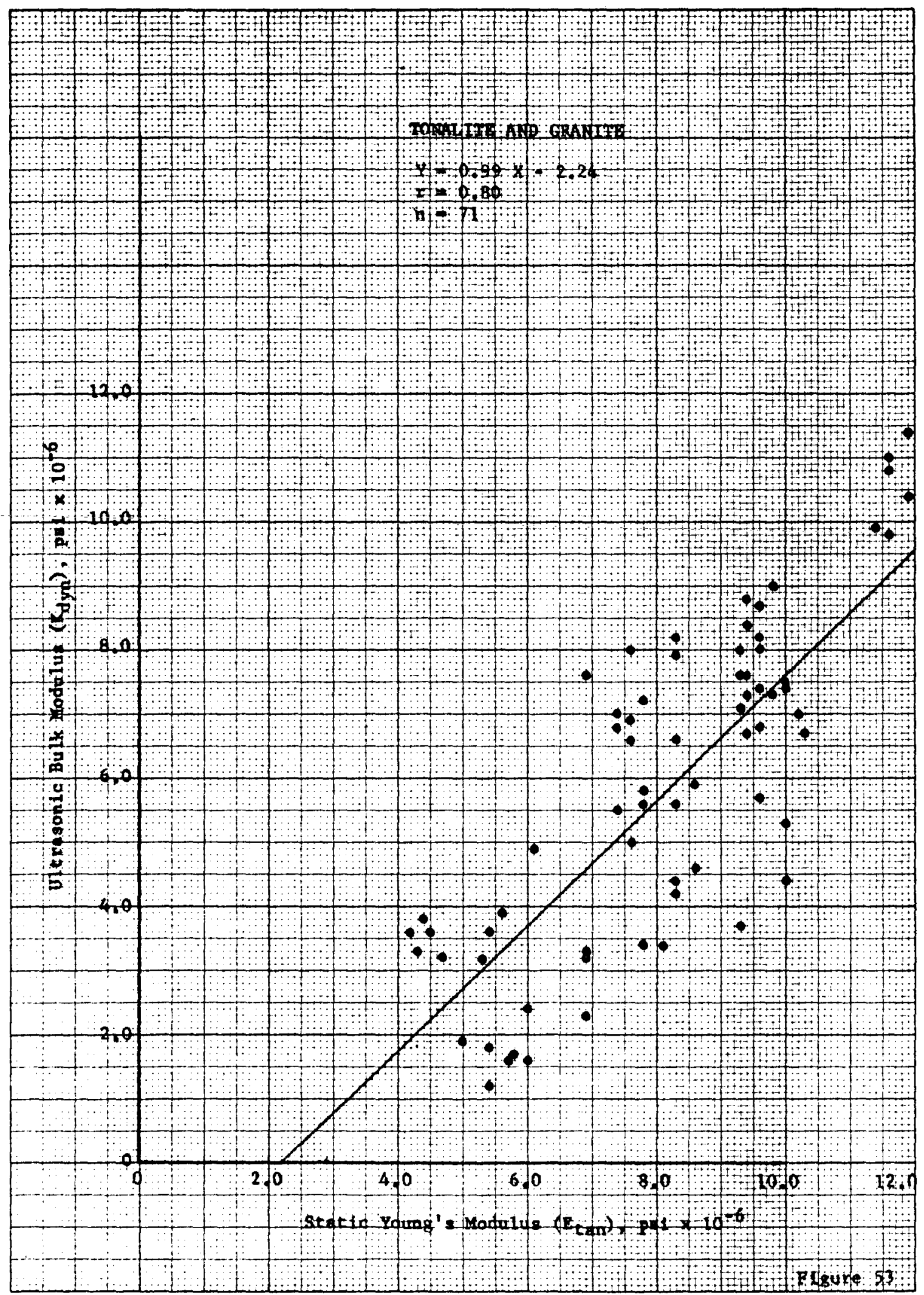


Correlation coefficionte determined for tro of these paira ( $E_{\text {tan }}$ versus $E_{d y n}$ and $E_{\text {tan }}$ versus $G_{d y n}$ ) rere among the highest jielded by correlation of any of the pairs of variables examined during the course of thi invertigation (Table 3 ). These two group of correlations were not suficiently aperior to those involving the easier to determine values of shear and compressional pul we velocity, horever, to alone juatify the additional time and money which is necessary to the computation of ultrasonic elastic moduli. This is not to say, horever, that computation of ultrasonic moduli might not be denirable for purposen other than phyaical property correlations. The general trende characteriatic of the phyoical property correlations discused in the section immediately prior to this one $\left(E_{\text {tan }}\right.$ veraun $v_{p}$ and $v_{s}$ ) were also noted to exiat for these correlations. Specifically, degrees of correlation determined for the Group 1 tonalite date group rere only elightly larger in magnitude than thoce jielded by the Group 2 tonalite data groupa for corresponding pairs of phymical properties, subatantiating previous indications that variation in grain size, as opposed to aignificant variation in mineral composition and geologic bistory as allored within the confines of apecific rock type, appear to be of primary agnificance in the determination of the degreo of acatter typical of variou phyaical property correlatione within the particular rock type.

1. was mentioned in the previous section, combination of the data for both rock typen, granite and tonalite, into a mgle otatiaticel cample and correlation of this angle mane of date did not, for either of the three paira of phyacal propertien considerod in 
this section, result in an appreciable sacrifice in quality of the correlation obtained for the granite data alone or the tonalite date alone. Thus, for these paira of phyaical properties and these rock types, variation in rock type appeared to have no ignificant effect on the quality of the correlations obtained.

$E_{\tan }$ Vorsua $v d j n$. Figures 54 through 57 graphically illustrate the general lack of linear aneociation observod to exist betreen tangent Young' modulus of elasticity and ultrasonic Poiseon's ratio.

Correlation coefficient: determined for this pair of rariables (four data groups) were, in most cases, appreciably larger than the ones obtained for the plote of ultimate uniaxial comprensive otrength versu Poisson a ratio. Examination of the acatier plots (Figures 54 through 57), horever, ravealed no ignificant trende to exist between the tro variablex. The higher correlation coefficient (yielded by the Group 3 data) had resulted solely from the location of eight data pointa, in thia inatance, pointe of questionable validity (values of Poismon's ratio were felt to be unreprenentative) in a manner wo as to give definite orientation to the least-squarea line rithout increasing the quality of the plot to one of actual significance (See Figure 56 ).

Thus, as was the case with the correlation of ultimate uniexial compreanive otrength with ultrasonic Poinson' ratio, the correlations determined for tangent Young' modulus of elasticity verau ultrasonic Poinaon' ratio rere all of little or no practical value from a property prediction point of view. 


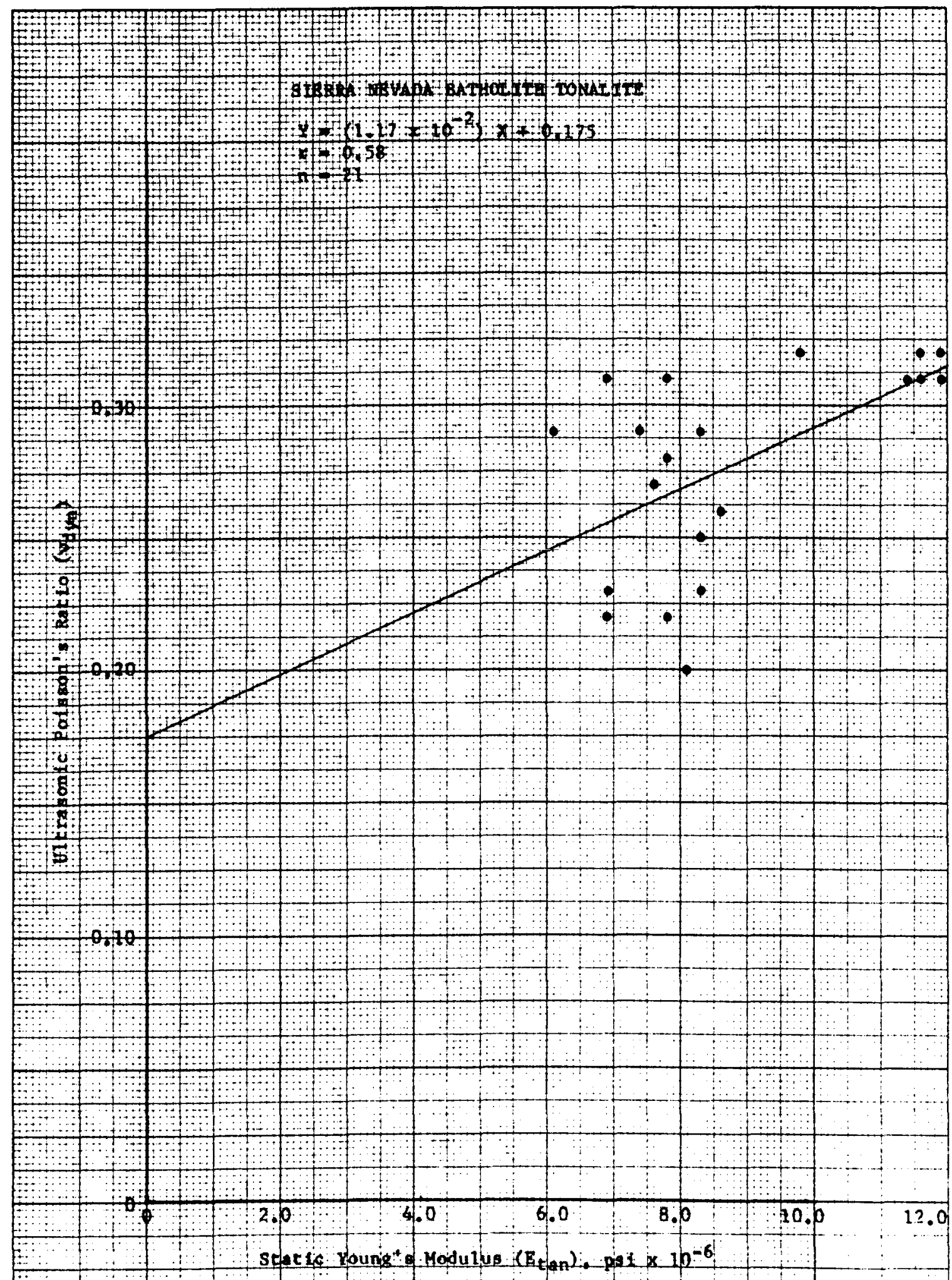

Figure 54 


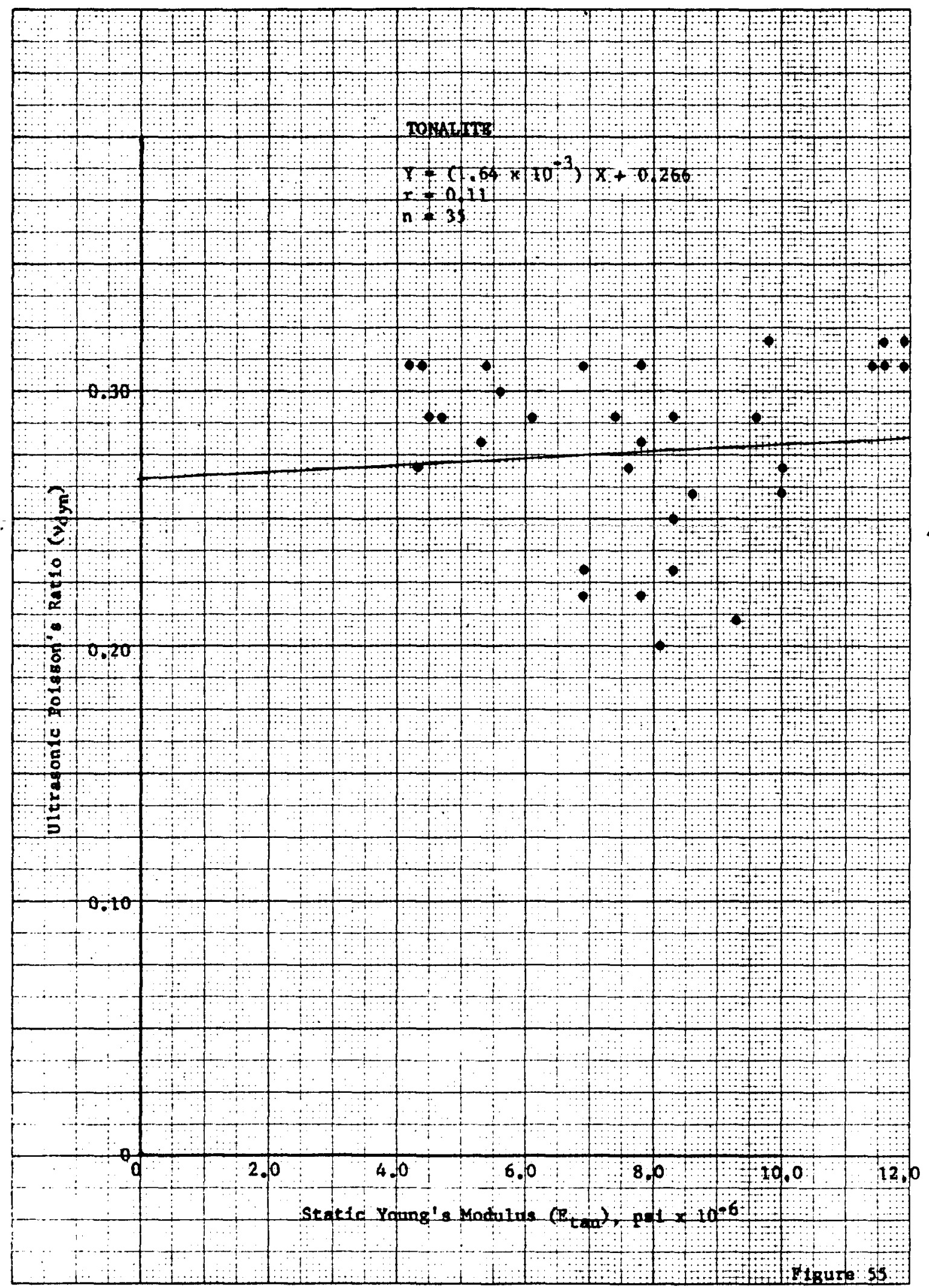




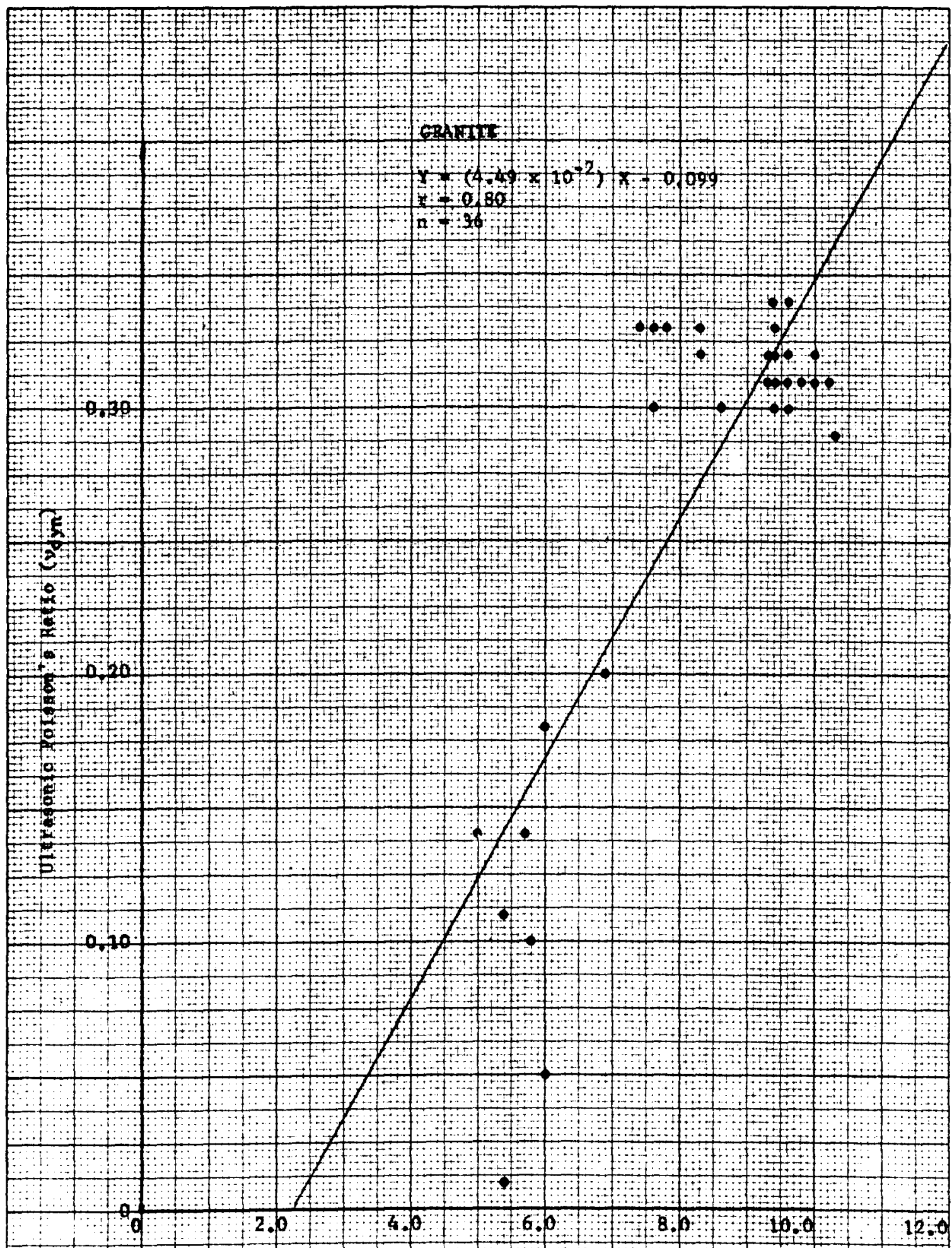

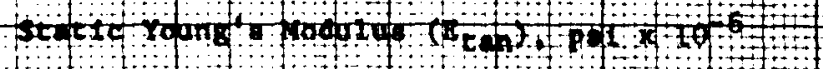









\section{CEUPTER 4}

\section{CONCLUSIONS AND RECOMOIENDATIONS}

\section{Concluaion:}

Baned upon reaulte of the phyeical property teate conducted during this inventigation, and on linear correlation of the rarious phyaical propertien determined for these graniten and tonalitea, the following conclusiona appear justified.

(a) Variation in grain aize rather than abstantial variation in percentage mineral composition and geologic hiatory as allowed within the confines of the opecific rock type (tonalite) appears to be the primary factor remponaible for the degree of acatter typical of data plote for the varioue paira of phyaical rock propertien examined for apecific intect rock type. It muat be kept in mind, however, that the tro rock types uned in this inventigation rere both intrusive igneous rocks and rere easentially of a homogeneous and inotropic nature. Thun, the above conclusion ahould be rentricted basically to igneous rock. It is folt that variation in geologic history would have substential influence on the degree of acatter typical of rock property correlations for metamorphic and cedimentary rock, particularly where there are wide variations in angles of inclination of planes of mivtosity and redimentation, and in degrees of cementation and recryatelization. 
(b) Variation in rock type appear to have generally undoeirable influence on the quality of the correlation obtained for various pairs of rock properties. Where correlations betreen tro particular phjaical propertien determined for variou individual rock typee are quite different in degree of lineor ansociation, amalgamation of the maller individual correlation into a ingle larger relationship inevitably result, in acrifice of quality and usefullnese of the good relationahips due to introduction of data exhibiting lesser degreen of correlation. Thin type of aituation was found to exist when the corresponding Group 2 and Group 3 correlations wich involved ultimate uniaxial compreneive trength ae one variable zere combinod end eraluated angle group (Group 4). A milar situation would result if the various phyoical proporty correlatione for the individual rock typen were of a differing nature (inclination or orientation) such that amalgamation of the individual correlation for a angle pair of properties into one large group would produce a large degree of acatter and thus a lesser degree of linear asacciation. This would probably be more likely to occur when greatly different rock typen were involved.

(c) A comparian of linear correlations involving ultraconic pulse velocitien with those involving ultrasonic elastic moduli indicated that linear relationuhipa in which oither ultraconic whear moduli or ultrasonic Young' moduli were employed an one variable were alightly muperior in quality to similar relationshipe in which one of the ultranonic pulne velocitien ras involved. The degree of superiority did not appear great onough, horever, to alone 
warrant the additional time and effort necenary to the determination of the ultrasonic elatic constante.

(d) Correlation which employ ultresonic ebear pulse velocity ac one variable appear to be ouperior in quality to aimilar correlations involving ultrasonic compresaional pulde relocity as one variable. Shear pulae velocity appeara to be the ultranonic phyaical property of those exanined in this otudy, which offors the best ponsibility for linear correlation with and preliminary prediction of ultimate uniaxial compreneive srength and tangent (atatic) Young' modulue of elasticity.

(e) It doen not appear likely that ultrasonic valued of Poinson' ratio have any appreciable value in the area rock property correletion and prediction.

\section{Recommendatione}

Aa indicated previouely, this investigation ras confined to two typen of igneoun rock. It is suggested that several varieties of metamorphic and sedimentary rocks be atudied in a mimilar manner to determine whether or not the trends observed in this investigation are typical of all rocks or are merely typical of igneous rock types. In particular, the effecta of variation in grain ize on the degree of acatter typical of phyaical property correlation for metamorphic and sedimentary rocks should be inventigeted, an it is folt that variation geologic hintory may here be of primary importance rather than variation in grain size.

An inventigation hould be made to determine the extent to which phymical property relations ouch as those investigated here might be 
better represented by curvilinear correlations rather than linear correlations. Several of the acatter diagrame in this study appeared to be of a nature that might be better represented by a second degree curve. In addition, a more extennive statiatical analysis (determine confidence limita, etc.) might be porformed to determine the practical value of ach phyaical property correlation for property prediction purposes.

Ultrasonic shear pulse velocity and ultrasonic shear modulus should be more thoroughly examined for use in auch phyaical property correlationa. It rould appear that these tro ultranonic properties offer the bent posaibilities of any of the ultranonic propertios used in this invortigation. 


\section{ABSTRACT}

Robert Wayne Criop, Haster of Science, 1971

Major: Civil Engineering

Title of thesias The Influence of Variation in Grain Size and Minimal Variation in Rock Type on the quality of Rock Property Correlations for Intact Igneous Rock:

Directed by: Dr. Robert M. Scholtes, Head, Department of Civil Engineering

Pages in Thesias 116. Worde in Abstract: 274

Correlations of phyaical properties of rock and prediction of one property from a previously determined value of another property nould be of tremendous value in the field of civil engineering. In particular, ach corrolationa and rock property predictions would expedite multiple aite evaluation and selection programa, and poneibly allow for reduction in the number of various test required to determine the phyaical propertien now deemed necenary for competent design and conotruction in rock media.

Provioue rock property correlations have generally oncompassed many rock typen, the objective being to determine general relationahipe typical of all rock types. The data, horerer, have frequently oxhibited auch a great degree of acatter that aubsequent correlationa 
were of questionable ralue. Thus, in an effort to eliminate some of the acatter typical of many previous rock property correlationa, thic investigation was conducted to determine the influence of variation in grain aize and minimal rariation in rock type on the quality of rock property correlations for intact igneous rock typen.

Phyical property teats rere conducted on 79 cylinderical specimens of granite and tonalite reprenenting 10 drill sitea. Values of ultimate uniaxial compressive otrength and static Young' modulus of elosticity (tangent) were correlated with valuen of ultraconic comprenionel puløe relocity, ultrasonic abear pulse velocity, ultrasonic Young's modulus, ultrasonic shoar modulus, ultrasonic bulk modulus, and ultranonic Poincon's ratio for each of the four following group of specimens:

Group 1: All tonalite apecimens tested from the Sierra Nevada Batholith, California.

Group 2: 111 tonalite apecimeno tested.

Group 3, All granite specimen tented.

Group 4: A11 apecimens tested.

Comparison of the nature and quality of these linear correlations revealed that variation in grain oize, os opposed to variation in mineral composition and geologic history as allowed within the confines of a particular rock type, appears to have primary influence on the degree of acatter typical of rock property correlations for a particular intact igneous rock type. Moreover, rock property correlations involving only one igneous rock type are generally superior to those involving severel igneous rock types, the 
latter cane frequently suffering from an overall lack of quality due to a larger degree of scatter brought about by the amalgamation of data relationebipe exhibiting different trende and difforent degrees of linear ansociation. 


\section{APPLANDI I}

PETROGRAPHIC DESCRIPTIONS

AND

POLISHED SFCTION PHOTOGRAPHS 


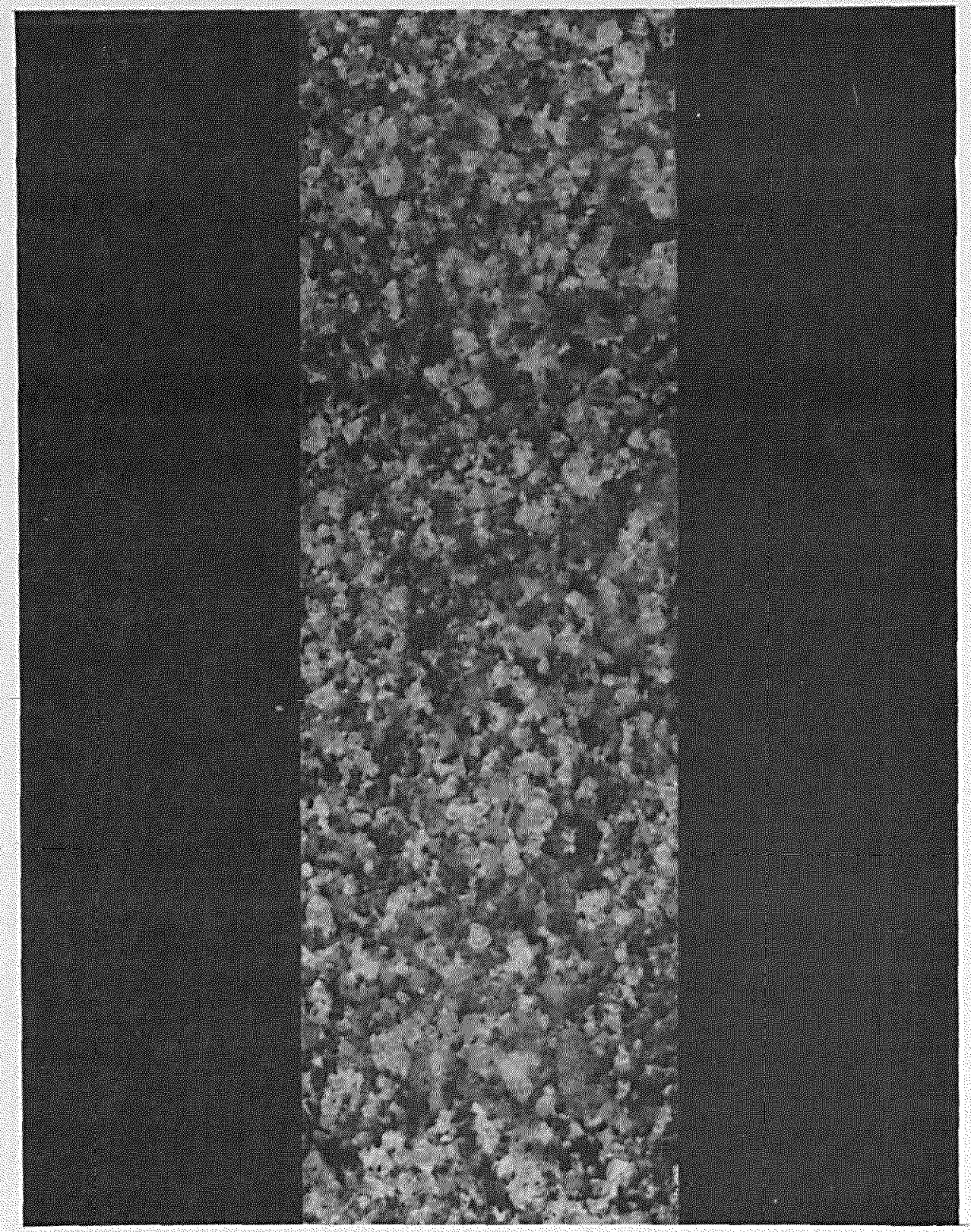

(a) Tonalite (Vermilion granite formation, Minnesota). Bromiah-gray medium- to coarse-gray tonalite. Biotite was broken and al tered to chlorite. Microcline was unal tered and unbroken. Composed of $29 \%$ quartz, $48 \%$ plagioclase feldspar, $18 \%$ potasaium feldspar (microcline), and $2 \%$ biotite vith traces of magnitite, apatite, sphene, zircon, and calcite. Very few microfractures vere detected. 




(b) Granite (Lucerne Pluton, Maine). Black and white, coarsegrained granite. Porphyritic texture. Specimens wero unweathered and contained very fer microfractures. Contained $28 \%$ quartz, $30 \%$ plagioclase feldapar, $30 \%$ potamium feldapar (microcline), and $11 \%$ biotite with trace of magnitite, apatite, chlorite, pidote, and hematite. Plagioclase wa alightly altered to sericite. 




(c) Granite (Granite Mountaina Uplift, Wyoming). Unweathered brownish-gray, coarse-grained granite. Microfracturea were somewhat conmon. Contained $30 \%$ quartz, $30 \%$ plagioclase feldapar, $33 \%$ potaaaium feldspar (microcline), $5 \%$ biotite, $1 \%$ chlorite, and $1 \%$ magnetite and tracen of epidote, apatite, and zircon. Anorthite content of the plagieclase was 15\%. Plagioclase was slightly al tered to sericite. Biotite was alightly altered to chlorite. 


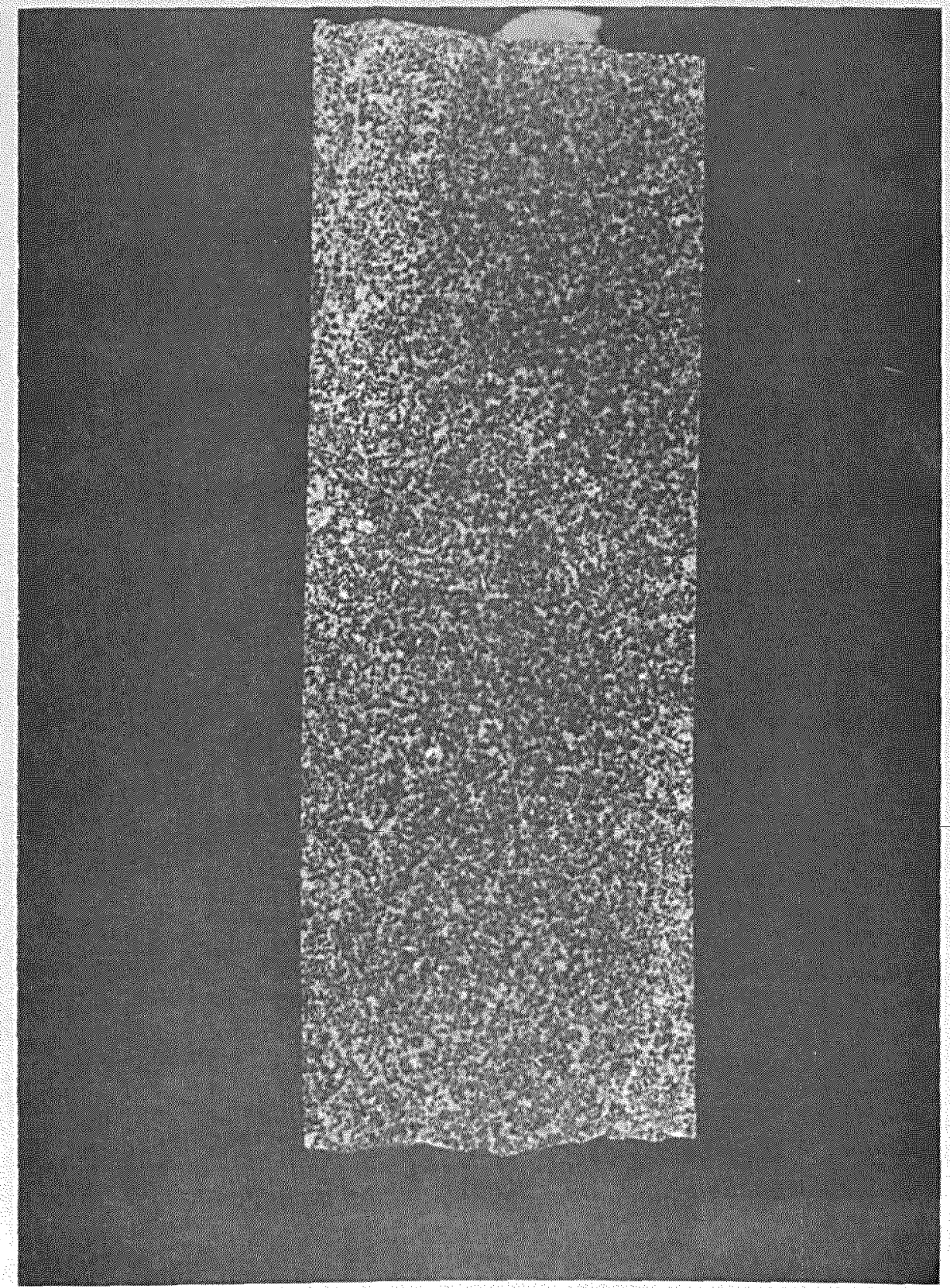

(d) Tonalite (Sierre Nevada Batholith, California). Finegrained, dark colored rock. Sections were fresh and contained no macrofractures. Contained 18\% quartz, $42 \%$ plagioclase foldapar, $19 \%$ hornblende, $16 \%$ biotite, $4 \%$ chlorito and traces of microcline and other accosary winerals. The biotite was sightly altered to chlorito. 


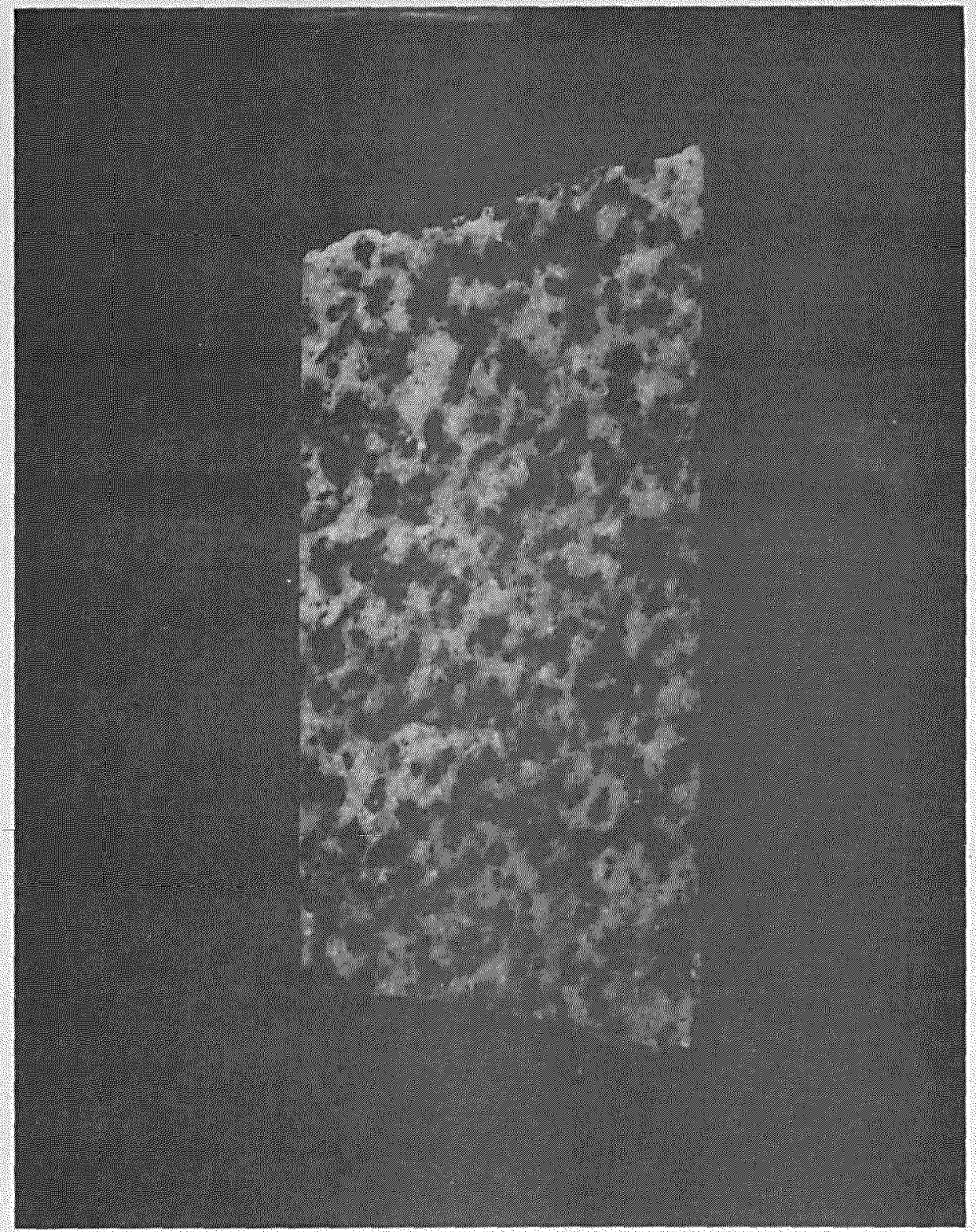

(e) Tonalite (Sierra Novada Batholith, California). Medium- to coarae-grained, bleck and white tonallte. Sectiona ware freah and intact. Percutage ninerel compoutions vere $21 \%$ quartu, $45 \%$ plagioclane feldepar, 13\% hornblende, 20\% biot1to, and 1\% chlorite. Tracea of microcline were al ao detected. The biotite wa 11 ighty altered to chlorite. 


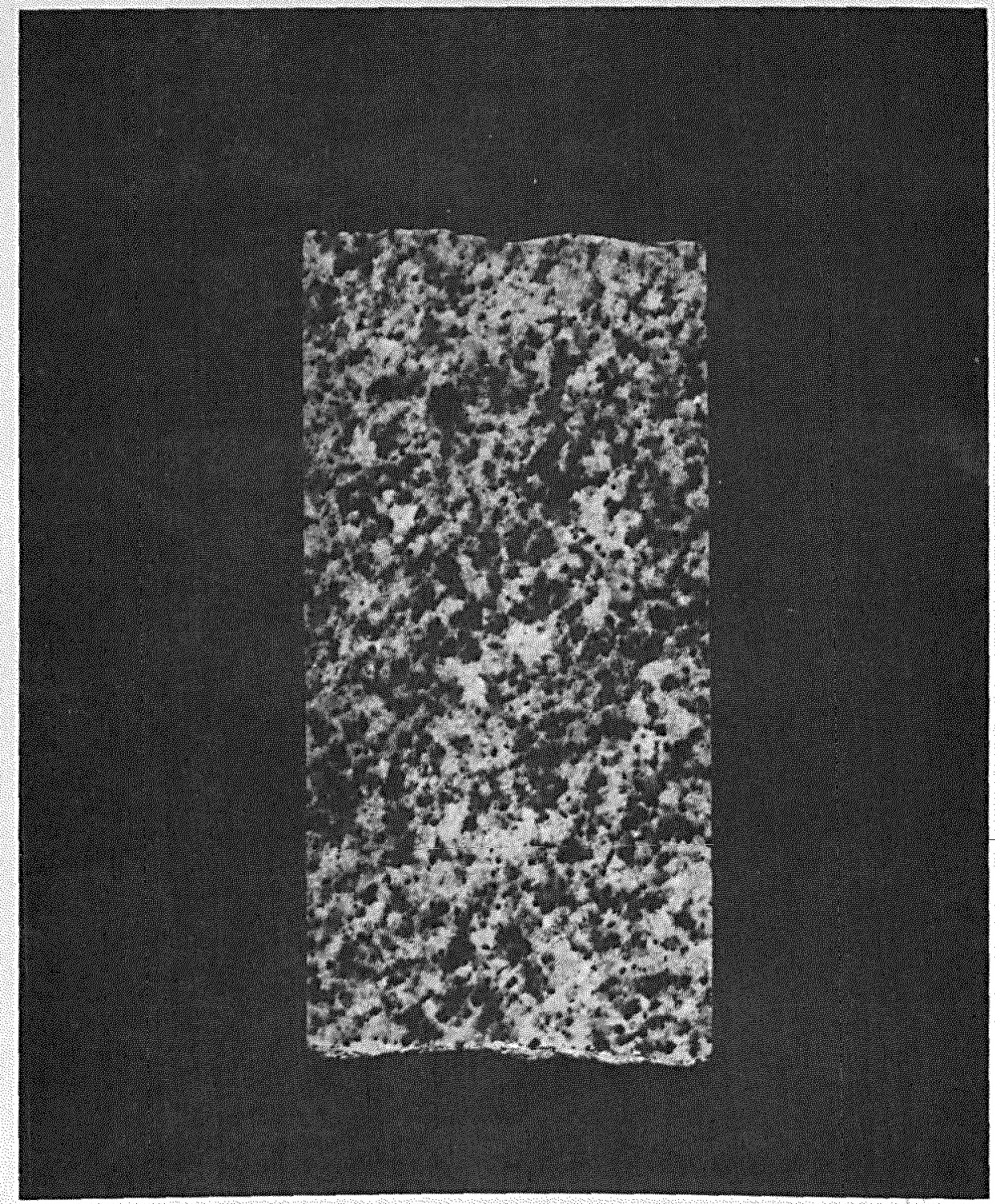

(f) Tonalite (Sierra Nevada Batholith, California). Mediumgrained, black and white tonalite, much finer grained than the medium- to coarme-grained tonalite (e). Sections were unveathered. Porcentage mineral compositiona ver $19 \%$ quartz, $46 \%$ plagioclase feldapar, $2 \%$ microcline, $12 \%$ hornblende, and $21 \%$ biotite. Traces of chlorite and magnetite were also detected. The biotite had been alightly altered to chlorito. No macrofractures were detected. 


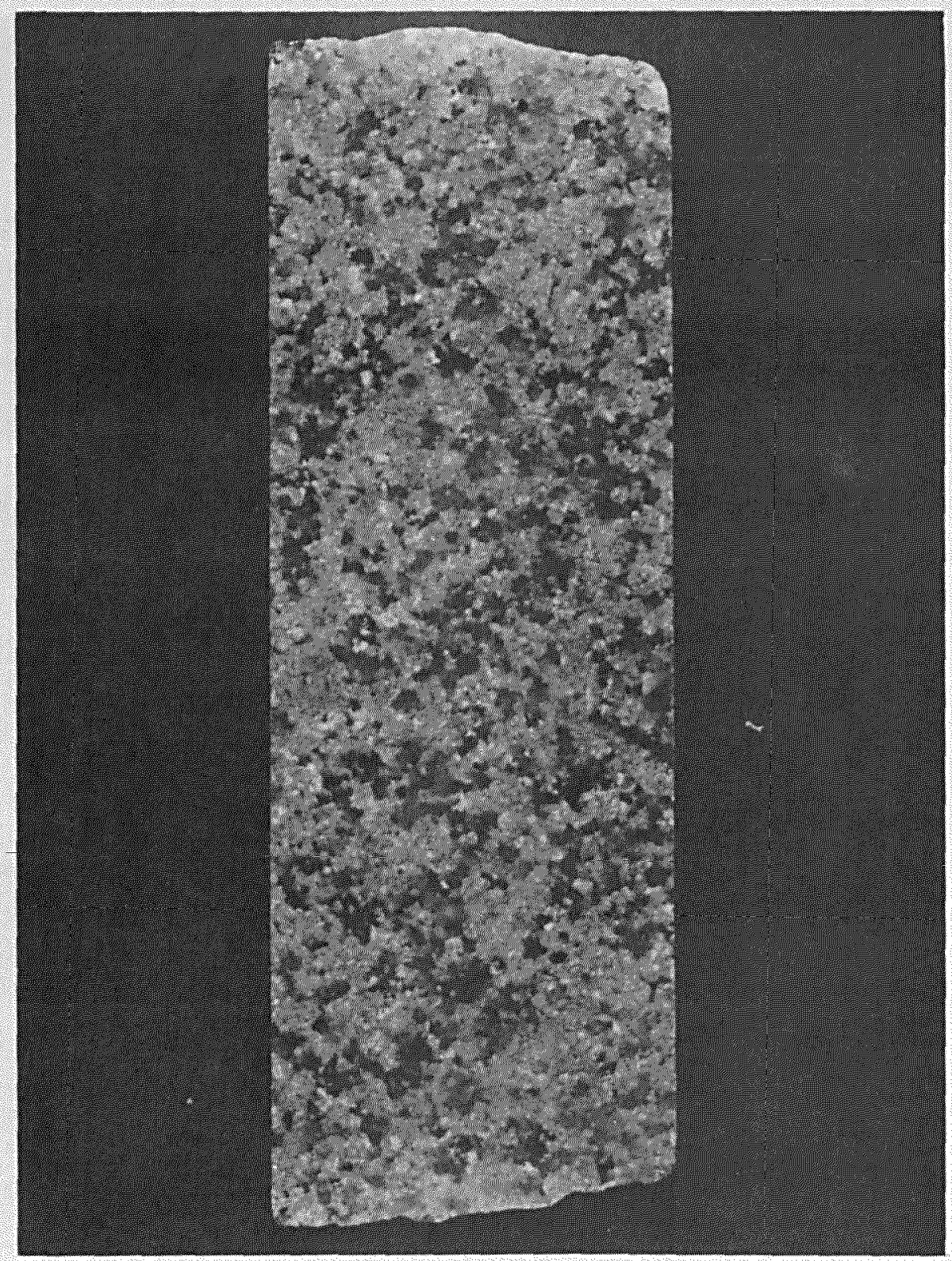

(g) Granite (Northweat of Lone Grove Pluton and Enchanted Rock Batholith, Texan). Modium-grained, red granite. Sectiona vere intact and unreathered. More muscorite mica present than biotite mica. Percentage mineral composition is $30 \%$ querts, $28 \%$ plagioclase feldapar, 33\% potasaium foldapar (microcline), and $9 \%$ biotito with traces of hornblende and chlorite. 


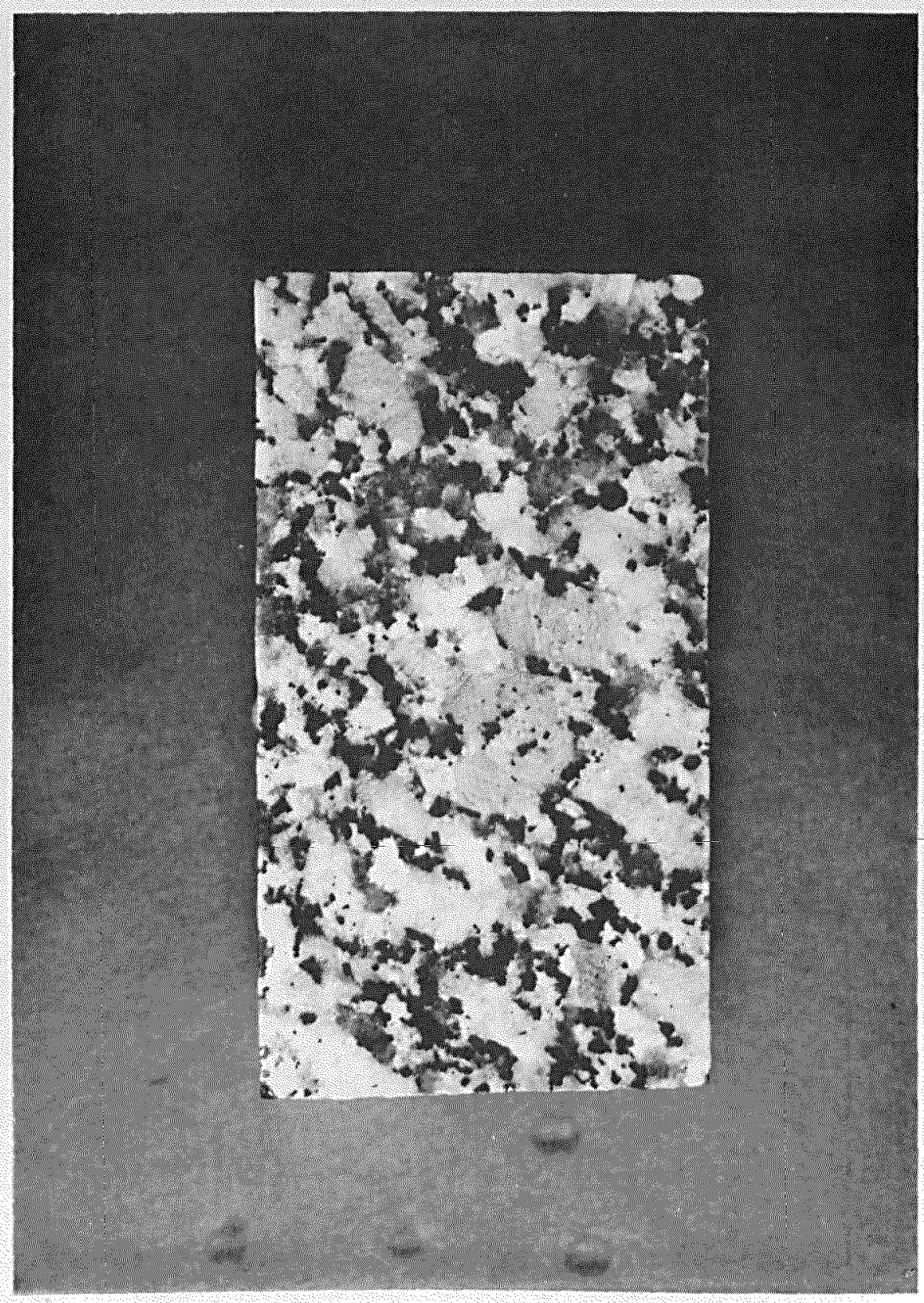

(h) Granite (Sherman Granite Facien of Southern Laramie Range). Light-gray, coars-grained granite. Compoaed of $24 \%$ quartz, $30 \%$ plagioclame Peldapar, $32 \%$ potaniun feldapar (microcline), 10\% biotite, $4 \%$ hornblende, and a trace of chlorito. No preoxiating fracture surfacen could bo detected. 


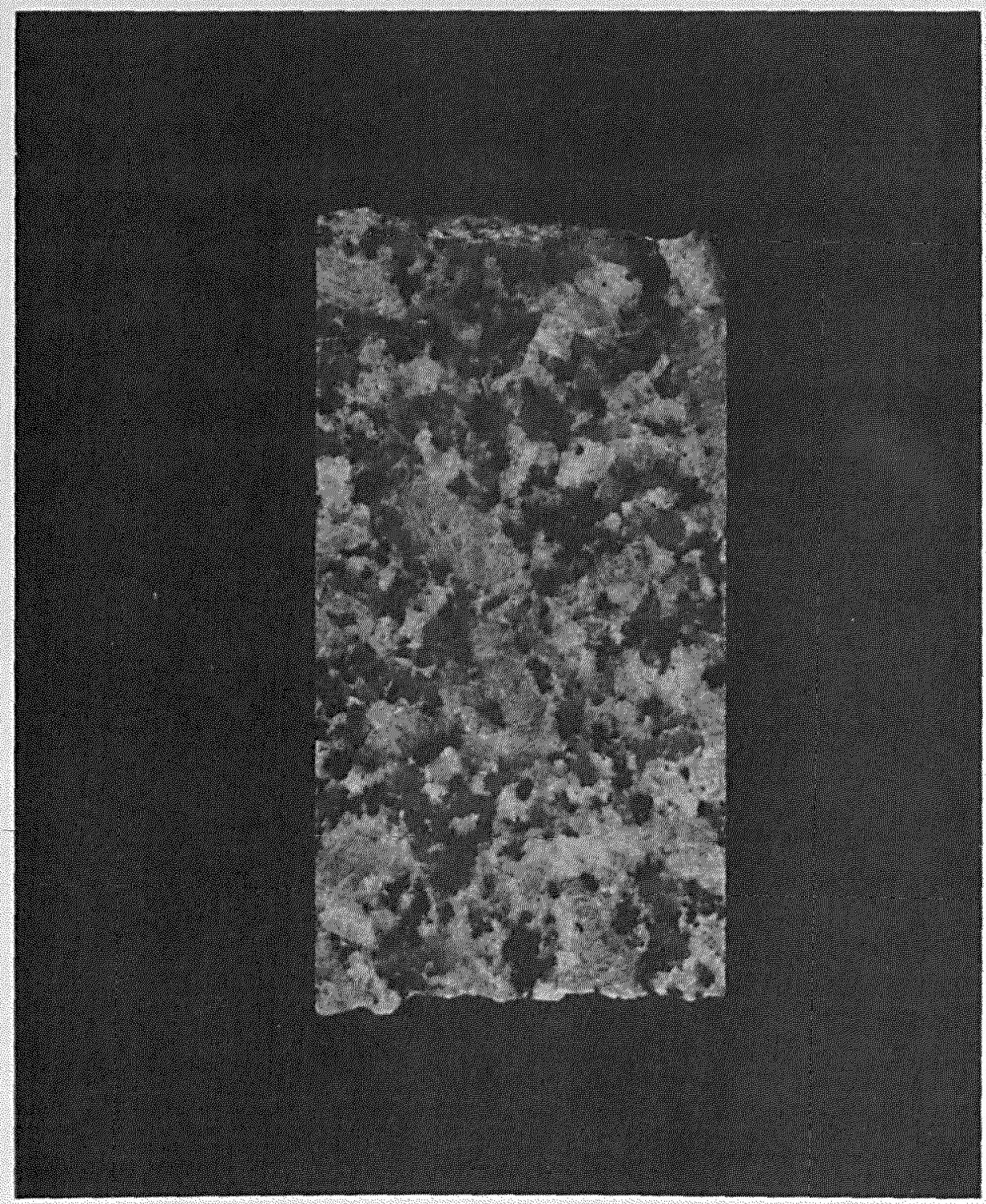

(i) Granito (Southern Laramie Range, Wyoming). Medium- to coarae-grained, pink granite, perphyritic texture. Percentage mineral compesition in $29 \%$ quartz, $30 \%$ plagioclase foldapar, $34 \%$ potasaium feldapar (microcline), $5 \%$ biotite, $1 \%$ hornblende, and $1 \%$ chlorite. Sectiona vere unweathered and macroscopically free of fractures. 


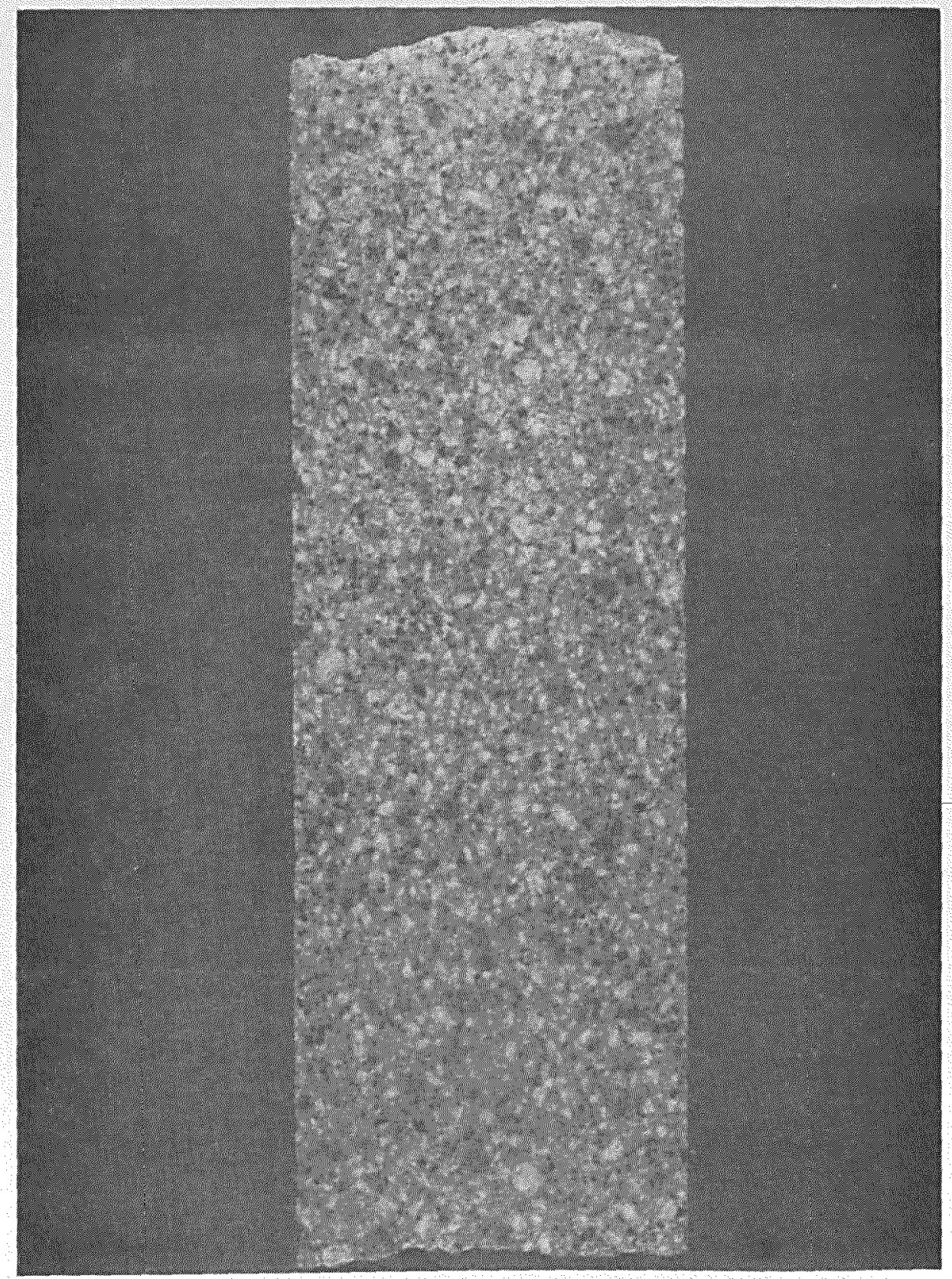

(j) Tonalit. (Codar City Tonalite, Utah). Light-gray, mediumgrained tonalite. Mineral componition in $20 \%$ quartz, $44 \%$ plagioclase foldspar, 3\% potasaium feldapar (micrecline), 21\% hornblende, 5\% biotito, $6 \%$ magnetit with tracen of chlorit and othor accensary minerala. Biotite waw wlightly altered to chlorite. Specimena wore unweathered and macroacopically free of fracturen. 
APPENDIX II

CRITICal vaIUES

OF

CORREIATION COEFFICIENTS 
Critical Values ( $\left.r_{c r}\right)$ of Correlation Coefficiente

\begin{tabular}{cc}
$\begin{array}{c}\text { Statiotical } \\
\text { Sampio } \\
\text { Size (n) }\end{array}$ & $\begin{array}{c}\text { Critical } \\
\text { Value (r r) }\end{array}$ \\
\hline 21 & 0.55 \\
35 & 0.43 \\
36 & 0.39 \\
39 & 0.40 \\
40 & 0.40 \\
71 & 0.30 \\
79 & 0.29
\end{tabular}


1. Blair, B. B. Phreical Propertien of kine Rock, Part III. United States Bureau of Mines, Report of Investigationn, 5130 , June 1855.

2. Chayen, Felix. Petrogrephic Modal Analreie, Ner York, John Viles and Sonn, Inc., 1966.

3. D'Andrea, D. V., et al. 'Prediction of Compresiive Strength From Other Rock Properties," Colorado School of Mines Quarterly, Vol. 59, No. 4 (October 1964), 623-640.

4. Deere, D. U., and R. P. Miller. Bngineering Claceification and Index Fropertiea of Intact Rock. Air Force Peapona Laloratory Technical Report No. LFWL-TR-6S-116, December 1866.

5. Fairhurat, C. Waboratory Measurement of Some Phyaical Propertien of Rock," Proceedinge of the Fourth Symposium on Rock Mechanice, Pennsylvania Steto Univeraity Mineral Induetries Experiment Station, Bulletin No. 76, April 1861.

6. Judd, W. R. Strain Dietribution Around Underground Openinge, Technical Report No. 2. Ldvanced Renearch Projecta Agency, Department of Defenee, December 1868.

7. Judd, W. R., and C. Huber. "Correlation of Rock Propertiea by Statiuticel Methods," Internetional Srmposium on Mining Research, 2 Vol., New York, Pergamon Presn, 1962.

8. Obert, I., and W. I. Daval1. Rock Mechanice and the Deaign of Structuree in Rock. New York, John Viles and Sone, Inc., 1867.

9. Obert, L., et al. Standardized Teete for Determining the Phraical Properties of Mine Rock. United Staten Bureau of Mines, Report of Inventigationa, 3891, Luguet 1946.

10. Rinehart, J.S., et al. Mropagation Velocity of Longitudinal Waves in Rocks - Bffect of State of Strese, Stress Level of the Wave, Water Content, Porosity, Temperature, Stratification, and Texture," Proceedinge of the Fourth Symposium on Rock Mechanica, Penniylvania State Univerbity Mineral Induntriea Brperiment Station, Bulletin No. 76, April 1961.

11. Shand, S. J. Bruptive Rocks. New York, John WileJ and Sona, Inc., 1949 .

12. U. S. Army Engineer Haterwaya Bperiment Station, Handbook for Concrete and Cement, August 1849. 
13. Williams, H., et al. Petrography. San Francisco, W. H. Freeman and Company, 1954. 
(Seciurlty classification of tltle, body of abstract and indexind annofation must be ontered when the overall report ls clasellled) JRIGINATING AC TIVITY (Cotporale suthor)

i. S. Ariny Engineer Waterways Fxperiment Station VicksburE, Mississippi 20. REPOAT SECURITY CLASSIFICATION Unclassified

REPORT TITLE

THE INFLUENCE OF VARIATION TN GRAIN SIZE AND MINIMAL VARIATTON IN ROCK TYPE ON THE QUALITY OF ROCK PROPERTY CORRELATIONS FOR INTACT IGNEOUS ROCKS

4. OESCAIPTIVE NOTES (Type of roport and inclusive datea)

Final report

5. AU THOR(S) (Fient namo, middlo initial, Tant namo)

Robert W. Crisp

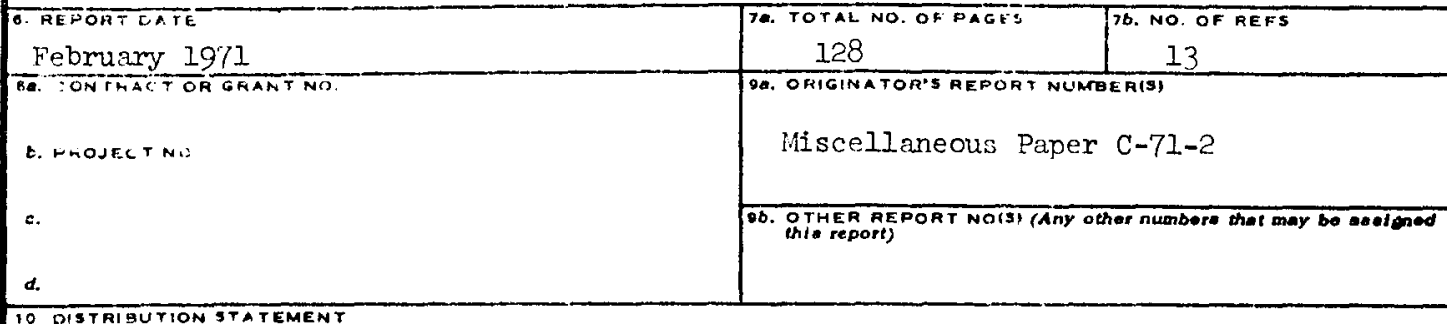

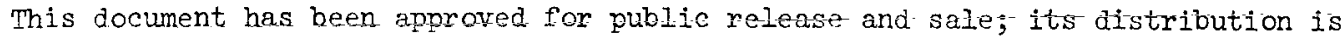
unlimited.

11. SUPFLEmentaprotes Report was also sub-

mitted to Mississippi State University,

State College, Miss., as thesis for degree

of Master of Science in Civil Engineering

13. ABstRAC Previous rock property correlations have generally encompassed many rock

types, the objective being to determine general relationships typical of all rock types The data, however, have frequently exhibited such a great degree of scatter that subsequent correlations were of questionable value. Thus, in an effort to eliminate some of the scatter typical of many previous rock property correlations, this investigation was conducted to determine the influence of variation in grain size and minimal variation in rock type on the quality of rock property correlations for intact igneous rock types Physical property tests were conducted on 79 cylindrical specimens of granite and tonalite representing $10 \mathrm{drill}$ sites. Values of ultimate uniaxial compressive strength and static Young's modulus of elasticity (tangent) were correlated with values of ultrasonic compressional pulse velocity, ultrasonic shear bulse velocity, ultrasonic Young's modulus, ultrasonic shear modulus, ultrasonic bulk modulus, and ultrasonic Poisson's ratio for each of the four following groups of specimens: (a) all tonalite specimens tested from the Sierra Nevada Batholith, Calif., (b) all tonalite specimens tested, (c) all granite specimens tested, and (d) all specimens tested. Comparison of the nature and quality of these linear correlations revealed that variation in grain size, as opposed to variation in mineral composition and geologic history as allowed within the confines of a particular rock type, appears to have primary influence on the degree of scatter typical of rock property correlations for a particular intact igneous rock type. Moreover, rock property correlations involving only one igneous rock type are generally superior to those involving several igneous rock types, the latter case frequently suffering from an overall lack of quality due to a larger degree of scatter brought about by the amalgamation of datg relationships exhibiting different trends and different degrees of linear assoclation. 
Unclassified

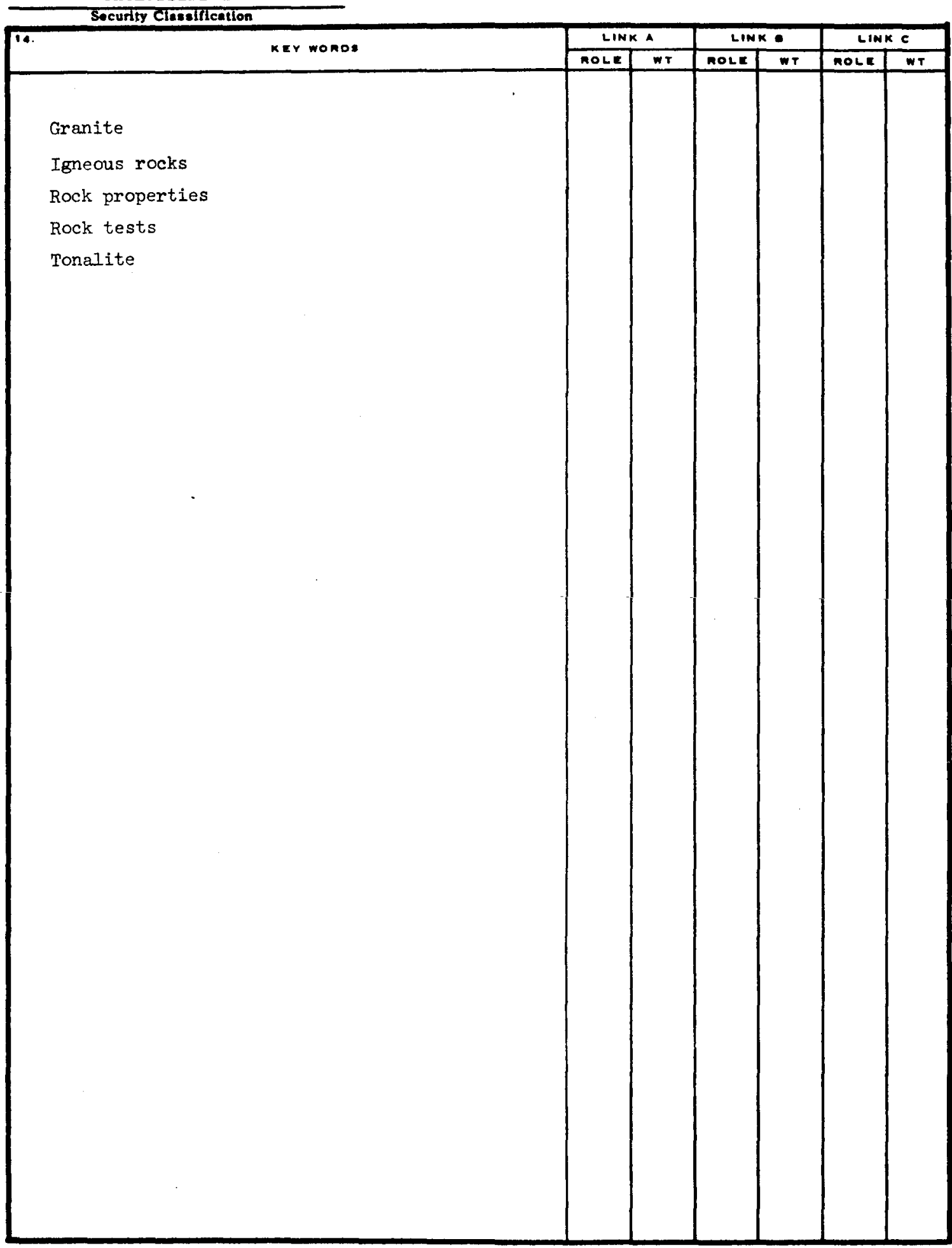

Unclassified 